\title{
ENVIRONMENTAL STATUS \\ OF THE HANFORD RESERVATION \\ FOR CY-1972
}

P.E. Bramson, J.P. Corley and W. L. Nees

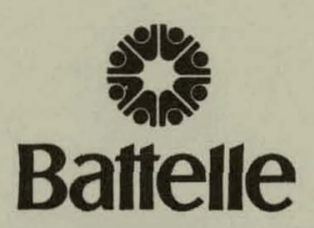

Pacific Northwest Laboratories

Richland, Washington 99352

\section{SEPTEMBER 1973}

This report is intended primarily for internal use by the sponsoring organization and Battelle. 


\section{DISCLAIMER}

This report was prepared as an account of work sponsored by an agency of the United States Government. Neither the United States Government nor any agency Thereof, nor any of their employees, makes any warranty, express or implied, or assumes any legal liability or responsibility for the accuracy, completeness, or usefulness of any information, apparatus, product, or process disclosed, or represents that its use would not infringe privately owned rights. Reference herein to any specific commercial product, process, or service by trade name, trademark, manufacturer, or otherwise does not necessarily constitute or imply its endorsement, recommendation, or favoring by the United States Government or any agency thereof. The views and opinions of authors expressed herein do not necessarily state or reflect those of the United States Government or any agency thereof. 


\section{DISCLAIMER}

Portions of this document may be illegible in electronic image products. Images are produced from the best available original document. 


\title{
NOTICE
}

The report was prepared as an account of work sponsored by the United States Government. Neither the United States nor the United States Atomic Energy Commission, nor any of their employees, nor any of their contractors, subcontractors, or their employees, makes any warranty, express or implied, or assumes any legal liability or responsibility for the accuracy, completeness or usefulness of any information, apparatus, product or process disclosed, or represents that its use would not infringe privately owned rights.

\author{
PACIFIC NORTHWEST LABORATORY \\ operated by \\ BATTELLE \\ for the \\ U.S. ATOMIC ENERGY COMMISSION \\ Under Contract AT(45-1)-1830
}

Printed in the United States of America

Available from

National Technical Information Service

U.S. Department of Commerce

5285 Port Royal Road

Springfield, Virginia 22151

Price: Printed Copy \$5.45; Microfiche $\$ 0.95$ 
$B N W L-B-278$

\title{
ENVIRONMENTAL STATUS OF THE HANFORD RESERVATION FOR $\mathrm{CY}-1972$
}

\author{
by
}

P. E. Bramson, J. P. Corley, and W. L. Nees

Occupational and Environmental Safety Department

SEPTEMBER 1973
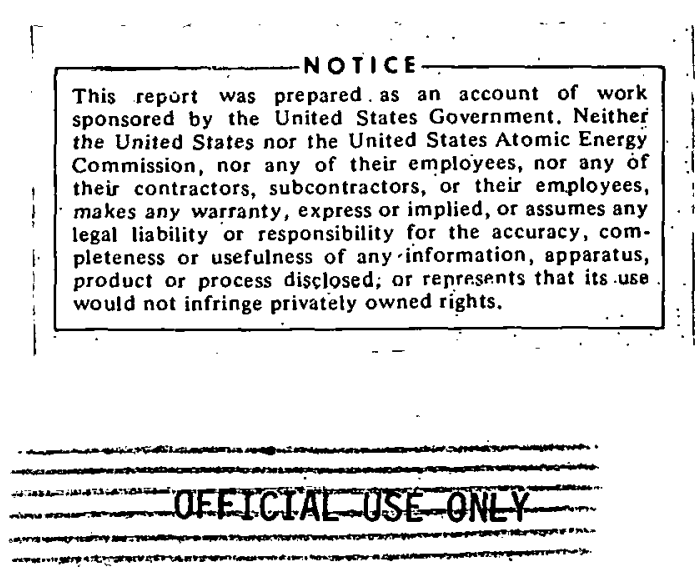
BNWL-B-278

\section{NOTICE}

This document contains data obtained within the Hanford reservation for the use of the Atomic Energy Commission and its contractors. It does not provide the evaluation of exposure for the off-site population, which is documented separately. 
. Page

I. INTRODUCTION $\ldots \ldots \ldots \ldots \ldots \ldots$

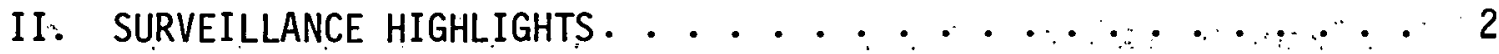

Columbia River Water . . . . . . ........ 2

Swamps, Ditches, and Ponds ................ 2

Airborne Radioactivity $\ldots \ldots \ldots \ldots . . . . . . . . .3$

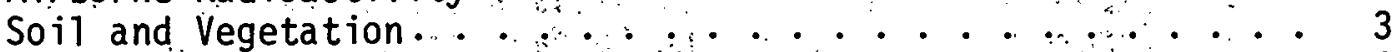

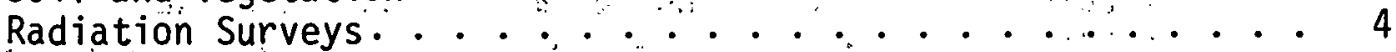

III. COLUMBIA RIVER WATER ............... 5

IV. DRINKING WATER ....................... 11

V. SWAMPS, DITCHES, AND PONDS ............. 13

A. 200 Area Waste Waters. ............. 13

B. 100-F Leach Trench .............. 14

C. 300 Area Waste Waters............. 14

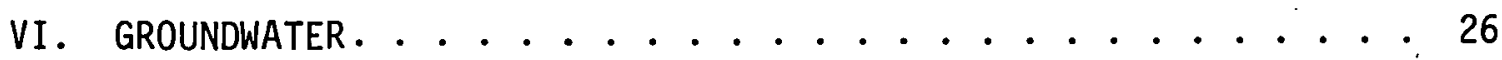

VII. BIRDS AND MAMMALS. ................. 27

Waterfowl. . . . . . . . . . . . . 27

Pheasants. . . . . . . . . . . . . . . . 27

Deer..................... . . 27

Small Mammals...................... 28

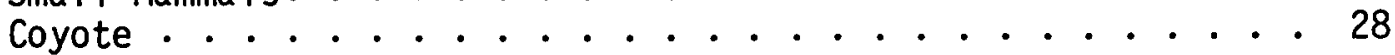

VIII. AIRBORNE RADIOACTIVITY . . . . . . . . . . 33

A. Iodine-131 ................... 33

B. Total Beta .................... 33

C. Total Alpha. . . . . . . . . . . . . . 34

D. Other Radionuclides. . . . . . . . . 34

IX. SOIL AND VEGETATION. . . . . . . . . . . . . 49

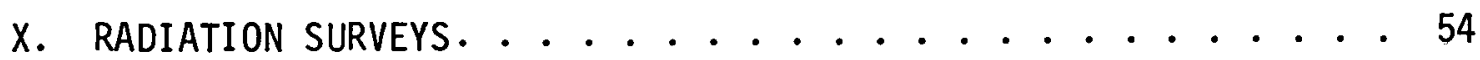

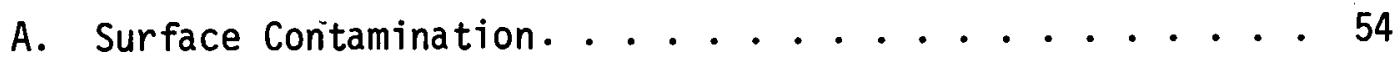

1. Hanford Roads Survey ............. 54

2. Railroad Survey. ............ 54

3. Aerial Survey. ............. 56

4. Control Plots. . . . . . . . . . . . 56

5. Waste Disposal Sites............ 56 
BNWL-B-278

TABLE OF CONTENTS (Continued)

Page

$X:$ RADIATION SURVEYS (Cont'd)

B. External Exposure Rates ............ 60

1. Exposure Rates On-Plant ............ 6 60

2. 100-N Area............... 62

3. Exposure Rates at the Columbia River Shoreline. . . : 62

4. Exposure Rates Below the Surface of the Columbia River .................. 63 


\section{LIST OF TABLES}

Table

1. Columbia River Biologịcal Analyses for 1972 ........ 8

2. Columbia River Chemical Analyses for $1972 \ldots \ldots$

3 Concentrations of Radionuclides in Columbia River Water

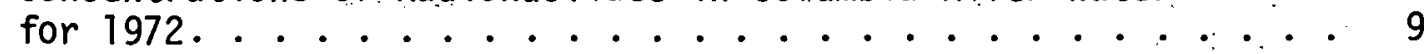

4. Gamma Activity in Waste Water Samples - $1972 \ldots \ldots \ldots$. . 21

5: Fluoride Ion Concentrations in the 300 Area Process Pond - 1972. 23

6:- Biological Measurements of Samples Collected from the 300: Area Leaching Trench and its Associated River Shoreline Seepage Area - 1972. ....................... 24

7 Average Radionuclide Concentrations in Muscle of Gamebirds -: 1972. . . . . . . . . . . . . . . . 29

8 Average Concentrations of Selected Radionuclides in the. Livers of Waterfowl Samples in the Hanford Environs - 1972. . 30

9 Concentrations of Several Radionuclides in Deer $-1972 \ldots \ldots 30$

10 Concentrations of Several Radionuclides in Small Animals - 197231

11: Average ${ }^{131}$ I, Particulate Total Beta, and Particulate Total Alpha Concentrations in the Atmosphere - 1972..... 38

12131 I. Particulate Total Beta, and Particulate Total Alpha in the Atmosphere - $1972 \ldots \ldots 39$

13 Averaqe Concentrations of Gamma Emitters and Plutonium on: Selected Air Filters $-1972 \ldots . \ldots \ldots \ldots \ldots \ldots . \cdots 41$

$14 \%$ Concentrations of Radionuclides in Soil Samples - 1972 _. . 51

15 Concentrations of Radionuclides in Vegetation - 1972. . . . 53

16 Average External Gamma Exposure Rates (mR/day) - $1972 \ldots 65$

17 Maximum Readings from Monthly Shoreline Surveys for 1972. . . . 66

18 Average Exposure Rates Below the Surface of the Columbia River $(1970-1972) \ldots \ldots 68$ 


\section{LIST OF FIGURES}

Figure

$\underline{\text { Page }}$

1 Nitrate Concentrations in Columbia River Water : . . . . . 10:

2 Radioactivity of Waste Water Samples, 200-East Area. . . . . 17

3 Radioactivity of Waste Water Sample, 200-East Area (216-B-63 Ditch).................... 18

4 Radioactivity of Waste Water Samples, 200-West Area. . . . . . 19

5. Radioactivity of Waste Water Samples, 220-West, 100-F Areas. . 20

6 Wastë Water Analyses, 300 Area . . . . . . . . . . . . 22

7 : Radioactivity of Waste Water Samples, 300 Area . . . . . . . 25

8 Total Beta Activity in - the Atmosphere - 100 Areas and Vicinity (Vernita Bridge, 100-K Area, 100-H Area) . . . . . . . . . 42

9 Total Beta Activity in the Atmosphere - 100 Areas and Vicinity (100-N Area, 100-D Area, 100-F Area)........... 43

10 Total Beta Activity in the Atmosphere (Hanford and Yakima Barricade)........................ 4 44

11 Total Beta Activity in the Atmosphere - 200 Areas (200-West Redox, 200-West East Center) .............. 45

12. Total Beta Activity in the Atmosphere - 200 Areas and Intermediate Areas (200-East Southeast, 200-East North Center, and Rattlesnake Springs)................ 46

13 Total Beta Activity in the Atmosphere, Intermediate Areas (Emergency Relocation Center, Wye Barricade) : . . . . . . 47

14 Total Beta Activity in the Atmosphere, 300 and 700 Areas . . . 48 


\section{LIST OF MAPS}

Map

Page

1 Columbia River Water Sampling Locations ........... 7

2 Drinking Water Sampling Locations . . . . . . . . . 12

3 Swamps, Ditches, and Pond Water Sampling Locations....... 16

4 Air Sampling Stations ................ 36

5 Off-Site Sampling Locations . . . . . . . . . . 37

6 Soil and Vegetation Sample Locations. . . . . . . . . . . 50

7 Hanford Road Surveys. . . . . . . . . . . . . 55

8 Aerial Survey Flight Patterns 1,2 and 3......... 57

9 Aerial Survey Flight Patterns 4 and $5 \ldots . . . . . .58$

10 Control Plot Locations. . . . . . . . . . . 59

11 Underground and Surface Radioactivity .......... 61

12 On-Piant External Radiation Exposure Rate Measurement Points . . . 64

13 Columbia River Shoreline Survey Locations and Exposure Rate Mea surement Points................ 69 


\section{ENVIRONMENTAL STATUS OF THE HANFORD RESERVATION FOR 1972}

\section{INTRODUCTION}

This report summarizes data collected during.1972 from locations within the Hanford plant boundaries (but generaliy outside areas under the control of individual contractors) for the environmental surveillance program, under the direction of the Environmental Evaluations staff. These environmental data are reported here for the information of the Richland Operations Office of the Atomic Energy Commission and its contractors.

The previous report in this series is BNWL-B-228, "Environmental Status of the Hanford Reservation for 1971." Graphs in this report show 14 months of data---the subject 12 months and the preceding two. Groundwater data are not included in this report but are presented most recently in BNWL-1737(1) and BNWL-1752. (2) Data from off-site sampling locations for 1972 are given in BNWL-1727. (3) Some data from off-site locations are included in this report for comparison with similar measurements made on-site.

. The majority of radiochemical analyses presented in this report were performed by the U.S. Testing Company, Inc., on samples collected by Battelle-Northwest. The term "analytical limit," as used herein, is the concentration at which the laboratory can measure a radionuclide with a precision of \pm 100 percent at the 90 percent confidence level. The detection 1 imit for a specific radionuclide varies with sample type, sample size, counting time, and the amounts of interfering radionuclides present. The "analytical limits" represent upper bounds to these fluctuating detection limits.

(1) K.L. Kipp, Radiological Status of the Groundwater Beneath the Hanford Project, January-June 1972, BNWL-1737, Battelle-Northwest Laboratories.

(2) K.L. Kipp, Radiological Status of the Groundwater Beneath the Hanford Project, JuTy-December 1972, BNWL-1752, Battel7e-Northwest Laboratories.

(3) P.E. Bramson and J.P. Corley, Environmental Surveillance at Hanford for CY-1972, BNWL-1727, with Addendum, BNWL-1727 ADD, Battelle-Northwest Laboratories, April, 1973. 
II. SURVEILLANCE HIGHLIGHTS

Columbia River Water

The 100-KE Reactor was shut down in January, 1971, leaving 100-N Reactor as the only remaining plutonium-producing reactor, and no reactors using river water for once-through primary cooling. Some lowlevel radioactive wastes continued to be discharged to the ground and to the river during the year.

Measured concentrations of $5 r-90$ and total alpha activity in river water averaged, respectively, $5 \times 10^{-10}$ and $5.4 \times 10^{-10} \mu \mathrm{Ci} / \mathrm{ml}$ at Vernita and $3.5 \times 10^{-10}$ and $6.7 \times 10^{-10} \mu \mathrm{Ci} / \mathrm{ml}$ at Richland during the year. Tritium

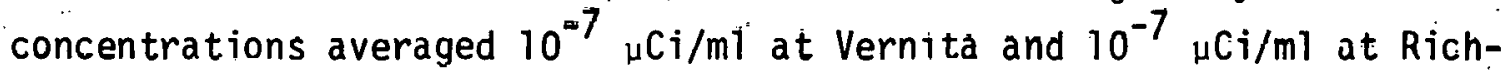
land.

The estimated annual GI tract dose for employees drinking 100-N water was $1.6 \mathrm{mrem}$, a decrease of about a factor of 2 from 1971. Radionuclide concentrations in drinking water at $100-\mathrm{H}$ were measured during occupancy by non-AEC contractor personnel. GI tract dose was estimated at $3.2 \mathrm{mrem}$ for 1972. Average concentrations of coliform bacteria in Columbia River water were slightly higher than 1971 averages but the increase was not attributed to Hantord operalioins. Thcsc and other water quality measurements---pH, turbidity and dissoived oxygen----Indicated continued compliance with Washington State Water Quality Standards.

Swamps, Ditches, and Ponds

Radionucl ide concentrations in samples collected from open waters on the Hanford project during 1972 were, in general, within their expected range of variation and were well below the plant working 1 imit of $5 \times 10^{-5}{ }_{\mu \mathrm{Ci}} / \mathrm{ml}$. The source of uranium alpha activity in excess of $10^{-7} \mu \mathrm{Ci} / \mathrm{ml}$ in Honey $\mathrm{Hill}$ Pond was not identified.

Concentrations of radionuclides in gamebirds and mammals sampled on or near Hanford swamps and ponds were generally below levels recorded in 1971.

Results of radiological, chemical, and biological analyses of samples collected from 300-Area ponds and trenches were generally within the expected range. Coliform and enterococci concentrations in the 


\section{SURVEILLANCE HIGHLIGHTS (Continued)}

Swamps, Ditches, and Ponds (Continued)

300 Area leach trench were somewhat higher than for 1971, and

. this was reflected in higher concentrations in the river shoreline seepage area.

\section{Airborne Radioactivity}

Concentrations of I-131 in the atmosphere, measured in charcoal samplers were below $2 \times 10^{-14} \mu \mathrm{Ci} / \mathrm{ml}$. The maximum sample concentration measured during this reporting period was $10^{-14} \mu \mathrm{Ci} / \mathrm{ml}$, noted in May at the 300 Area.

At most locations, both on-site and off-site, the average total beta activity was similar to 1971 except that no pronounced summer peaking was observed. The maximum measured beta activity, $3 \times 10^{-11}$ $\mu \mathrm{Ci} / \mathrm{ml}$, occurred in October at a 200-East Area location. Annual average activity ranged from $10^{-13}$ to $2 \times 10^{-13} \mu \mathrm{Ci} / \mathrm{ml}$ and $2 \times 10^{-13}$ to $3 \times 10^{-13}$ $\mu \mathrm{Ci} / \mathrm{ml}$ in the 100 and 200 Areas, respectively. Off-site beta activity ranged from $10^{-13}$ to $3 \times 10^{-13} \mu \mathrm{Ci} / \mathrm{ml}$ and averaged about $2 \times 10^{-13} \mu \mathrm{Ci} / \mathrm{ml}$.

Total alpha concentrations in air during 1972 averaged about $2 \times 10^{-15} \mu \mathrm{Ci} / \mathrm{ml}$ at most locations. Analyses of composite samples a 11 showed less than $10^{-16} \mu \mathrm{Ci} / \mathrm{ml}$ plutonium.

\section{Soil and Vegetation}

Plutonium concentrations in soil and vegetation at perimeter sampling locations were lower than in 1971, but probably typical of general levels for the arid western states. Relatively higher plutonium concentrations were detected at several sampling sites near the 200 Areas. Zirconium-Niobium-95 and Cesium-137 were present in onsite soil and vegetation samples from near the 200 Areas at higher concentrations than at perimeter sites. Concentrations of gammaemitting radionuclides and Strontium-90 at perimeter sites are believed to be the result of regional fallout. 


\section{SURVEILLANCE. HIGHLIGHTS (Continued)}

\section{Radiation Surveys}

A few radioactive particles were found on Hanford roadways twice during the monthly road surveys. The most active was a particle reading $30,000 \mathrm{c} / \mathrm{m}$. The annual railroad survey revealed one contaminated spot. The recovered soil read $7.5 \mathrm{rads} / \mathrm{hr}$. Primary radionuclides were ${ }^{90} \mathrm{Sr}-\mathrm{Y}$ and ${ }^{144} \mathrm{Ce}-\mathrm{Pr}$. Occurrences were attributed to waste haul ing operations.

The only radioactivity found on the control plots in 1972 was fallout from a Chinese weapons test and a discarded luminous clock face, not of Hanford origin. Nothing was found lhat could be attributed to the Hanford operations.

The waste disposal sites audited were generally in good condition except for a piece of contaminated material found outside the 300 West disposal site.

There was a slight upturn in the external exposure rates at most locations this year. The maximum average exposure rate noted was $1.8 \mathrm{mR} /$ day at 200-East Area. On the basis of exposure rate measurements off-site and at IUU-N, the whule-body do se to WPPSS porsonnel from Hanford sources of external radiation at 100-N during 1972 was estimated to be $5 \mathrm{mrem}$. 
III. COLUMBIA RIVER WATER

Columbia River, water sampled upstream of the Hanford project at Vernita is analyzed for comparison with samples collected downstream of the project at Richland to determine overall plant effects on Columbia River water. These results are reported in the annual off-site environmental surveillance report. (3) In addition, sampling is done at intermediate locations to detect localized influences on plant drinking water or river water quality (see Section IV). Sampling locations for raw Columbia River water are shown in Map 1.

Fallout radionuclides $\mathrm{H}-3$ and $\mathrm{Sr}-90$, as well as total alpha activity, were measured in monthly composites of weekly grab samples at Vernita and in monthly composites of weekly integrated samples at Richland. The measured concentrations of Sr-90 and total alpha activity in river water averaged, respectively, $5.0 \times 10^{-10}$ and $5.4 \times 10^{-10} \mu \mathrm{Ci} / \mathrm{ml}$ at Vernita, and $3.5 \times 10^{-10}$ and $6.7 \times 10^{-10} \mu \mathrm{Ci} / \mathrm{ml}$ at Richland during the year. Measured tritium concentrations averaged $10^{-7} \mu \mathrm{Ci} / \mathrm{ml}$ at Vernita and $10^{-7}$ at Richland. Averages were based on the actual sample results, which in many instances were less than the analytical limits.

Biological measurements of Columbia River water samples collected monthly from Vernita, 100-F, 300 Area, and North Richland appear in Table 1. From the Washington-Oregon border to Grand Coulee Dam, the Columbia is considered a Class A river, according to the Washington State Water Quality Standards, * which state that for Class A rivers total coliform organisms shall not exceed median values of 240 per $100 \mathrm{ml}$ with 1 ess than $20 \%$ of the samples exceeding 1000 per $100 \mathrm{ml}$ when associated with a fecal source. In addition to coliform, enterococci is measured to indicate contaminants of fecal origin. Normal seasonal peaking was observed during the summer months. Standards do not appear to have been exceeded during the year. Riverbank spring sampling indicates that the increase in the average col iform count between Vernita and North Richland (from 49 to 88 ) is not related to Hanford operations and was not of fecal origin.

*IIImplementation and Enforcement Plan for Water Quality Standards, Surface Waters," State of Washington, Dept. of Ecology, January, 1973. 
BNWL-B-278

III. COLUMBIA RIVER WATER (Continued)

$B O D$ and nitrate analysis was also performed on the weekly samples of river water from Vernita and Richland. Turbidity, $\mathrm{pH}$, and dissolved oxygen measurements obtained at Vernita and 300-Area were generally in compliance with Washingtion State Water Quality Standards. 
MAP 1

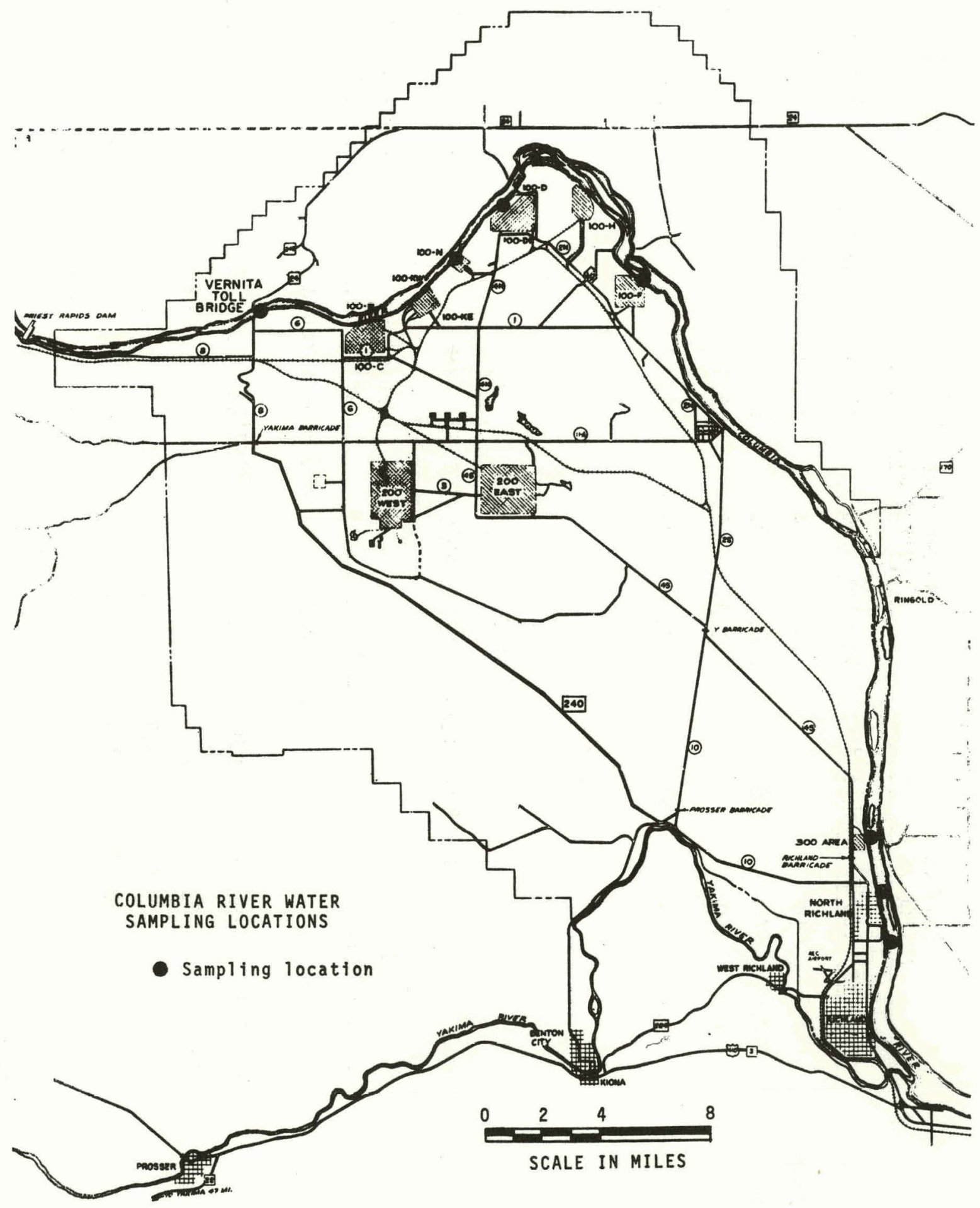


TABLE 1

COLUMBIA RIVER BIOLOGICAL ANALYSES FOR 1972

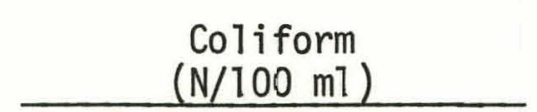

Vernita 100-F Richland

No. Samples

Maximum

Minimum

Average

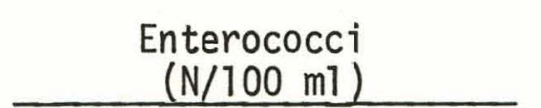

Vernita 100-F Richland

$\begin{array}{lll}14 & 14 & 11\end{array}$

28C. 88.88.

$\begin{array}{lll}1.0 & 0 . & 2.0\end{array}$

$3 \bar{i}$.

24.

34.

$\frac{\begin{array}{c}B O D \\ (\mathrm{ppm})\end{array}}{\text { Vernita } 100-\mathrm{F} \text { Richl and }}$

14

14

14

11

$\begin{array}{lll}4.1 & 4.0 & 4.2\end{array}$

$\begin{array}{lll}1.0 & 1.2 & 1.2\end{array}$

$\begin{array}{lll}2.6 & 2.5 & 2.9\end{array}$

TF.BLE 2

COLUMBIA RIVER CHEMICAL ANALYSES FOR 1972

\begin{tabular}{|c|c|c|c|c|c|c|c|c|}
\hline \multirow{3}{*}{ Standard } & \multicolumn{2}{|c|}{$\begin{array}{c}\mathrm{NO}_{3} \\
(\mathrm{ppm}) \\
\end{array}$} & \multicolumn{2}{|c|}{$\mathrm{pH}$} & \multicolumn{2}{|c|}{$\begin{array}{c}\text { Turbidity } \\
\text { (JTU) }\end{array}$} & \multicolumn{2}{|c|}{$\begin{array}{c}\text { Dissolved } \\
(\mathrm{ppm})\end{array} \mathrm{O}_{2}$} \\
\hline & \multicolumn{2}{|c|}{45} & \multicolumn{2}{|c|}{6.5 to 8.5} & \multicolumn{2}{|c|}{$5+$ Background } & \multicolumn{2}{|c|}{$8.0 \mathrm{~min}}$. \\
\hline & Vernita & Richland & Vernita & 300 Area & Vernita & 300 Area & Vernita & 300 Area \\
\hline No. Samples & 51 & 52 & 47 & 2.24 & 48 & 219 & 34 & 181 \\
\hline Maximum & 1.3 & 1.0 & 9.2 & 9.4 & 28. & 30. & 13.6 & 14.7 \\
\hline Minimum & * & 0.14 & 7.4 & 7.2 & 0.6 & 0.05 & 4.0 & 8.1 \\
\hline Average & 0.36 & 0.37 & 8.1 & 8.0 & 5.0 & 4.6 & 11.0 & 10. \\
\hline
\end{tabular}

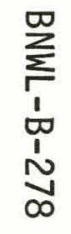

*Less than the analytical Timit. See Appendix D. 


\section{TABLE 3}

CONCENTRATIDNS OF RADIONUCLIDES IN COLUMBIA RIVER WATER FOR 1972

$$
\text { Units of } 10^{-9} \mu \mathrm{Ci} / \mathrm{ml}
$$

\begin{tabular}{|c|c|c|c|c|c|c|c|c|c|c|c|c|}
\hline \multirow[b]{2}{*}{ Radionuclide } & \multirow[b]{2}{*}{$\begin{array}{c}\text { (a) Analytical } \\
\text { Limit } \\
\end{array}$} & \multirow[b]{2}{*}{ C.G. } & \multicolumn{5}{|c|}{ VERNITA } & \multicolumn{5}{|c|}{ RICHLAND } \\
\hline & & & $\begin{array}{l}\text { No. of } \\
\text { Samples } \\
\end{array}$ & Max. & Min. & Avg. & $\begin{array}{l}\text { Percent } \\
\text { of C.G. }\end{array}$ & $\begin{array}{l}\text { No. of } \\
\text { Samples }\end{array}$ & Max. & Min. & Avg. & $\begin{array}{l}\text { Percent } \\
\text { of C.G. }\end{array}$ \\
\hline Alpha & 0.3 & 30 & 12 & 0.74 & 0.30 & 0.54 & 1.8 & 12 & 0.92 & 0.48 & 0.67 & 2.2 \\
\hline $3_{\mathrm{H}}$ & 220. & $3,000,000$ & 12 & 1400. & * & 110. & 0.003 & 12 & 1300. & * & 110. & 0.003 \\
\hline $32 p$ & 6.0 & 20,000 & & & & & & 11 & * & * & * & $<0.02$ \\
\hline${ }^{46} \mathrm{Sc}$ & 25. & 40,000 & 5 & * & * & * & $<0.01$ & 53 & * & * & * & $<0.01$ \\
\hline${ }^{51} \mathrm{Cr}$ & 20. & $2,000,000$ & 5 & 20. & * & * & $<0.01$ & 53 & 700. & * & 94. & 0.005 \\
\hline${ }^{60} \mathrm{Co}$ & 15. & 17,000 & 5 & 0.30 & * & * & $<0.01$ & 53 & 42. & * & * & $<0.02$ \\
\hline${ }^{65} \mathrm{Zn}$ & 2.0 & 100,000 & 5 & 2.0 & * & * & $<0.01$ & 4 & 2.0 & * & * & $<0.01$ \\
\hline${ }^{90} \mathrm{Sr}$ & 0.5 & 300 & 12 & 2.8 & * & 0.50 & 0.17 & 13 & 0.55 & 0.12 & 0.35 & 0.12 \\
\hline${ }^{131} 1_{I}$ & 1.0 & 300 & 5 & 5.2 & * & 1.2 & 0.67 & 26 & 6.4 & * & * & $<0.03$ \\
\hline${ }^{137} \mathrm{Cs}-137 \mathrm{~m}_{\mathrm{Ba}}$ & 3.0 & 20,000 & 8 & * & * & * & $<0.01$ & 7 & * & * & * & $<0.01$ \\
\hline${ }^{239} \mathrm{Pu}$ & 0.01 & 1,700 & 4 & 0.03 & * & 0.008 & 0.0005 & 4 & 0.06 & * & 0.02 & 0.001 \\
\hline
\end{tabular}

\footnotetext{
(a) See Appendix D.

*Less than the analytical 1 imit shown (see Appendix D).

No entry indicates no specific analysis was made.
} 
FIGURE 1

NITRATE CONCENTRATIONS IN COLUMBIA RIVER WATER

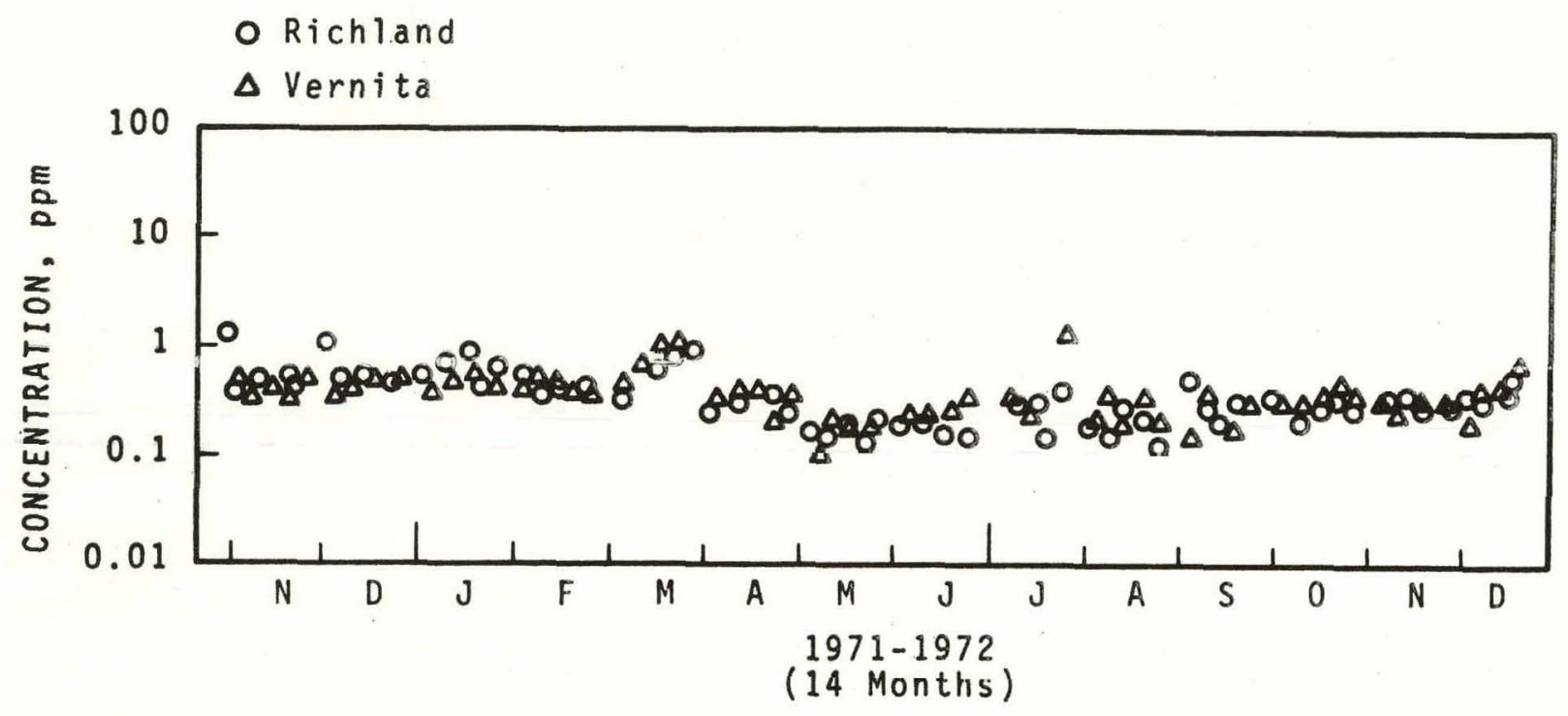


IV. DRINKING WATER

Drinking water was sampled at the four locations shown in Map 2. In December, 1971, several buildings in the 100-H Area were made available to a private contractor for use in a manufacturing venture. A monthly grab sample of the drinking water supply was initiated in December to monitor potential radiation dose to those employed at this site and was continued until December, 1972 when the contractor vacated the area. Average beta activity in $100-\mathrm{H}$ water was $.006 \mathrm{cpm} / \mathrm{ml}$ compared with $.003 \mathrm{cpm} / \mathrm{ml}$ at 100-N.

The GI tract dose from drinking 100-N water (Figure 2) was estimated from monthly isotopic and more frequent total beta analyses. The assumed water intake rate was 0.93 liters per day, five days a week, 50 weeks per year, as reported previously. The GI tract dose from drinking 100-N water was about 1.6 mrem during 1972, compared with 2.8 mrem during 1971 and 9.5 mrem during 1970. These GI tract doses represented 0.2 , and 0.6 percent, respectively, of the 1500 mrem per year dose standard for non-occupationally exposed individuals, or 0.02 and 0.06 percent of the yearly dose standard for occupationally exposed individuals $(15,000 \mathrm{mrem} /$ year). GI tract dose from drinking 100-H water was about 3.2 mrem during 1972. 
BNWL-B-278

MAP 2

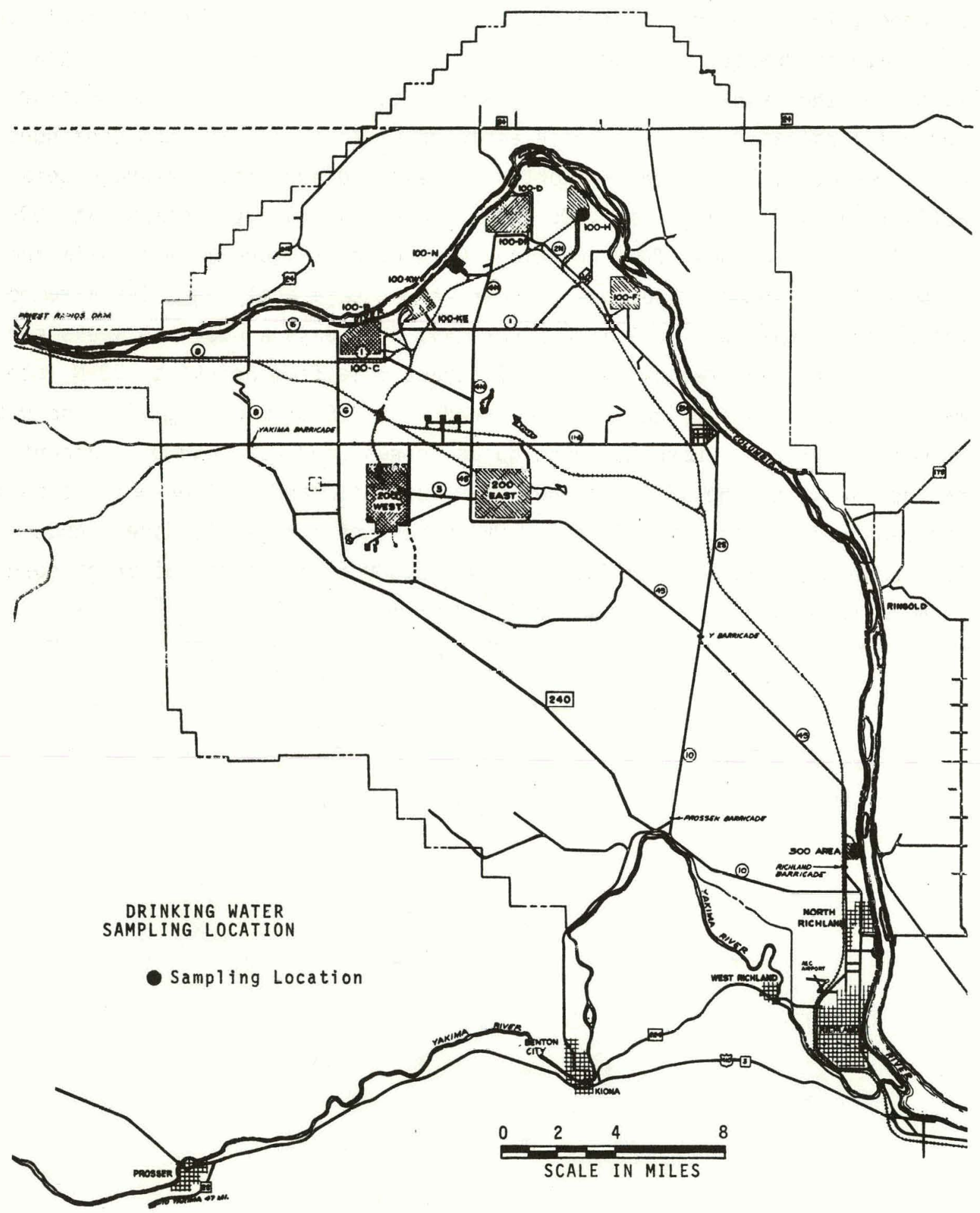


v. SWAMPS, DITCHES, AND PONDS

Open waters, primarily for disposal of cooling water, were sampled routinely at the locations shown in Map 3. Grab samples were collected monthly except that an integrated sample was collected weekly from the 300 Area Process Pond inlet. The sampling is not conducted for inventory purposes but rather serves as a surveillance of the radioactive contamination level in these waters. Total alpha and total beta concentrations were well below $5 \times 10^{-5} \mu \mathrm{Ci} / \mathrm{ml}$, the limit for open waters (AEC Manual, RL Supplement 0510).

300 Area Process Pond samples received both radionuclide and chemical analyses. Biological measurements were also obtained on samples from the 300 Area Sanitary Waste Leach Trench and its associated river shoreline seepage area.

\section{A. 200 Area Waste Waters}

The waste waters sampled in the 200 Areas are primarily cooling water from chemical processes and waste tanks. Monthly grab samples were collected from 222-S Swamp (216-S-19), T-Swamp (216-T-4), U-Swamp (216-U-10), Redox Swamp (216-S-16), Gable Swamp (216-A-25), B-Swamp (216-B-3), Chemical Sewer Emergency Ditch (216-B-63) and 231-Z Ditch (216-Z-11). Honey Hill Pond was added to the routine sampling in June, 1972 after a special sample revealed alpha concentrations in excess of $10^{-7} \mathrm{pCi} / \mathrm{l}$. Analysis results are presented in Figures 2,3 , 4, and 5, as well as Table 4. Alpha and beta activity in all swamps was within normal range of fluctuation. Due to ice, no samples could be obtained during November and December.

Swamp and pond samples received a quarterly gamma-emitter analysis (Table 4). From time to time the fallout radionuclides typically found in Columbia River water were also detected in samples collected from the swamps at concentrations similar to those found in Columbia River water. This is expected, since the Columbia River is the major source of process and cooling waters for the 200 Areas.

The source of the alpha activity in Honey Hill Pond has not been identified. There was no apparent surface water flow between Honey 
V. SWAMPS, DITCHES, AND PONDS (Continued)

A. 200 Area Waste Waters (Continued)

Hill Pond and Gable Swamp. Furthermore, Gable Swamp alpha activity is an order of magnitude less than Honey Hill. Sampling of groundwater and soil surfaces in the vicinity of Honey Hill Pond revealed no unusual alpha concentrations. Radioanalysis indicated that uranium was the source of the alpha activity detected in Honey Hill Pond.

B. 100-F Leach Trench

The 100-F Leach Trench receives waste water runoff from the 100-F Biology animal pens.

Sr-90 and alpha analysis of monthly grab samples collected from 100-F Leach Trench are presented in Figure 5. Average Sr-90 and alpha concentrations were $8.1 \times 10^{-7}$ and $3.3 \times 10^{-11} \mu \mathrm{Ci} / \mathrm{ml}$, respectively, for 100-F Leach Trench.

C. 300 Area Waste Waters

300 Area process pond receives manufacturing process and cooling water from fuel fabrication processes as well as cooling water and smal1 amounts of laboratory waste waters from the laboratory operations.

Total beta, uranium, nitrate ion, and hexavalent chromium concentrations measured in weekly cumulative samples, collected near the inlet of the 300 Area processing pond, are presented in Figure 6 . The concentration of uranium is based on a measurement of total alpha. Monthly average fluoride ion measurement results appear in Table 5. The average fluoride ion concentration for 1972 was $2.1 \mathrm{ppm}$, the same as for 1971.

300 Area Leach Trench receives sewer waste waters from the laboratory office and manufacturing facilities in the 300 Area. Samples were collected monthly from the 300 Area Leach Trench and from the river shorel ine seepage area. Analyses for coliform, enterococci (fecal bacteria), and BOD (biochemical oxygen demand) are summarized in Table 6 .

331 Pond receives waste waters from the 331 Building laboratories and effluent 1 iquor from the animal pen septic tanks. Monthly grab 
V. SWAMPS, DITCHES, AND PONDS (Continued)

C. 300 Area Waste Waters (Continued) samples were collected from 331 Pond. Analysis results for alpha and beta are presented in Figure 7 . Table 4 presents the results of quarterly gamma scans of 331 Pond water. Gamma-emitter concentrations were less than the analytical detection limit except for a sample in July which contained $4.4 \times 10^{-7} \mu \mathrm{Ci} / \mathrm{ml}{ }^{51} \mathrm{Cr}$. 


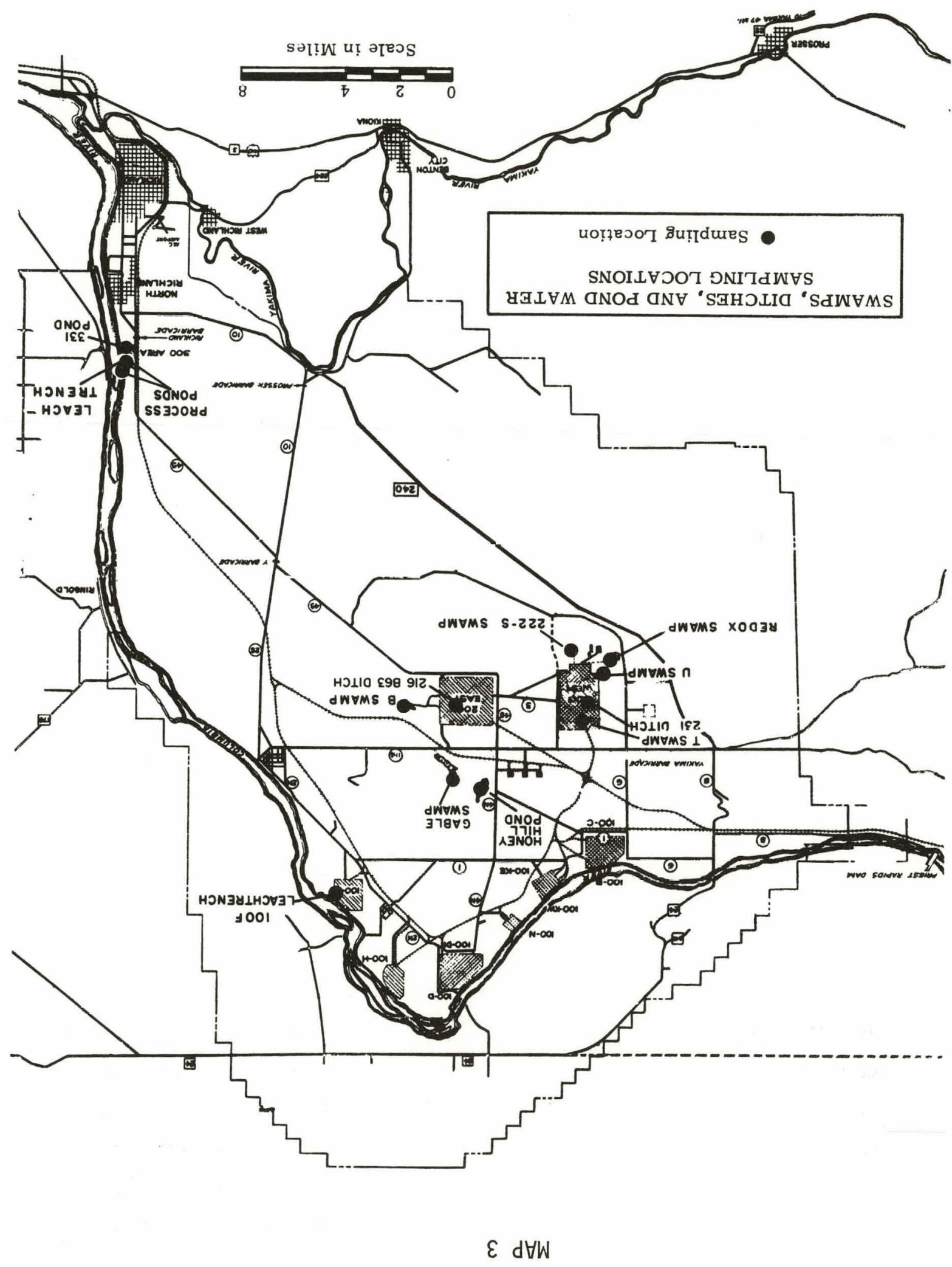


FTRIIRF ?

RADIOACTIVITY OF WASTE WÁTER SAMIPLES 200-EAST AREA
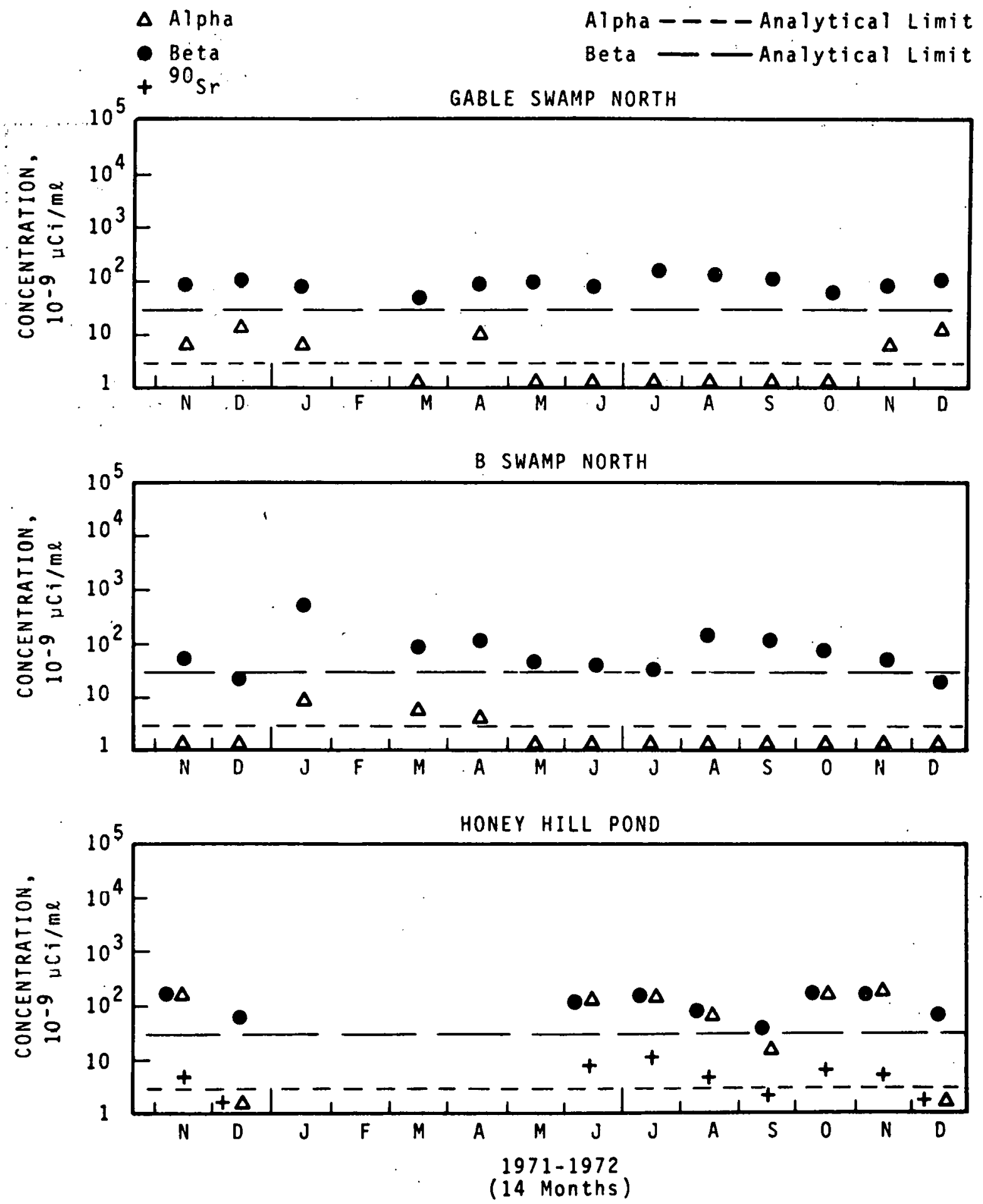
FIGURE 3

RADIOACTIVITY OF WASTE WATER SAMPLES

200 EAST AREA

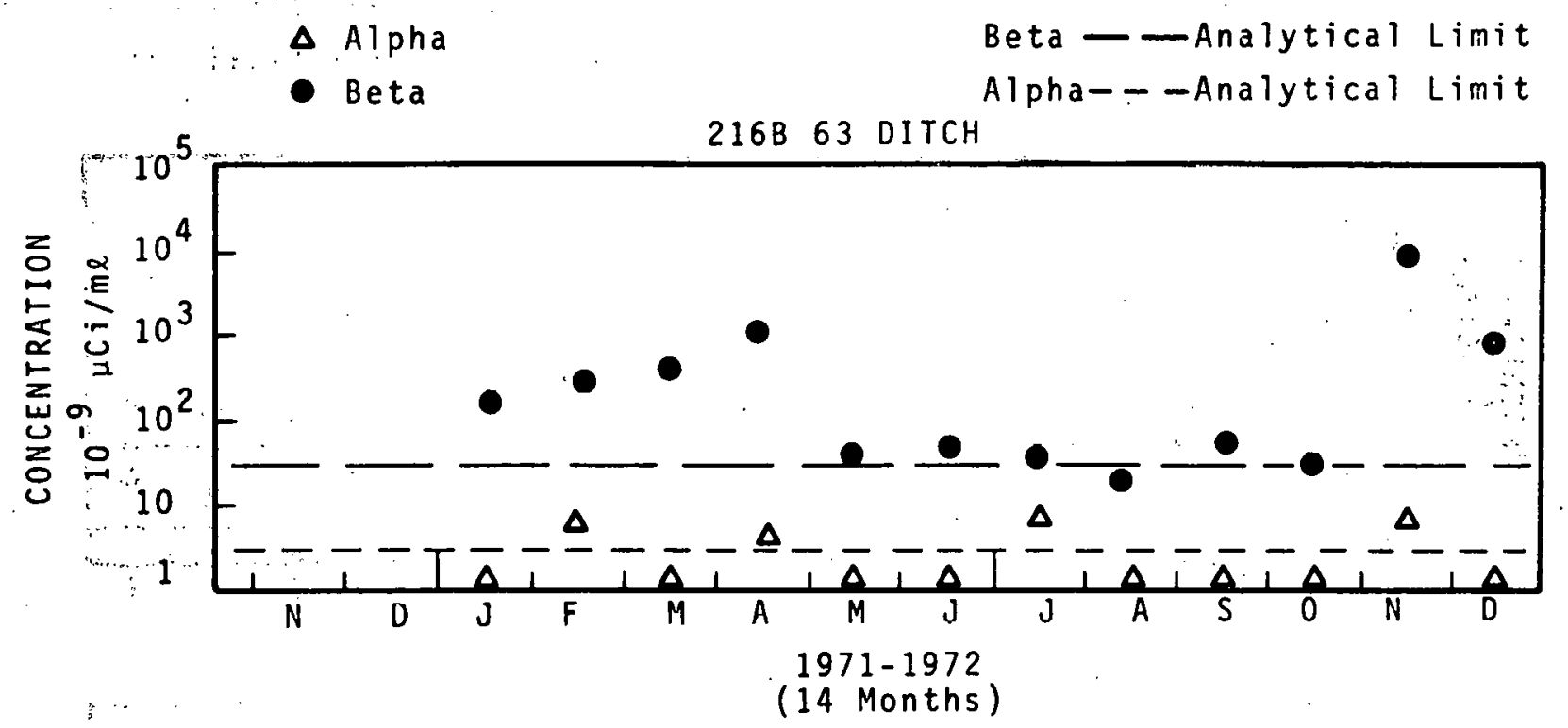


FIGURE 4

RADIOACTIVITY OF WASTE WATER: SAMPLES

200-WEST AREA
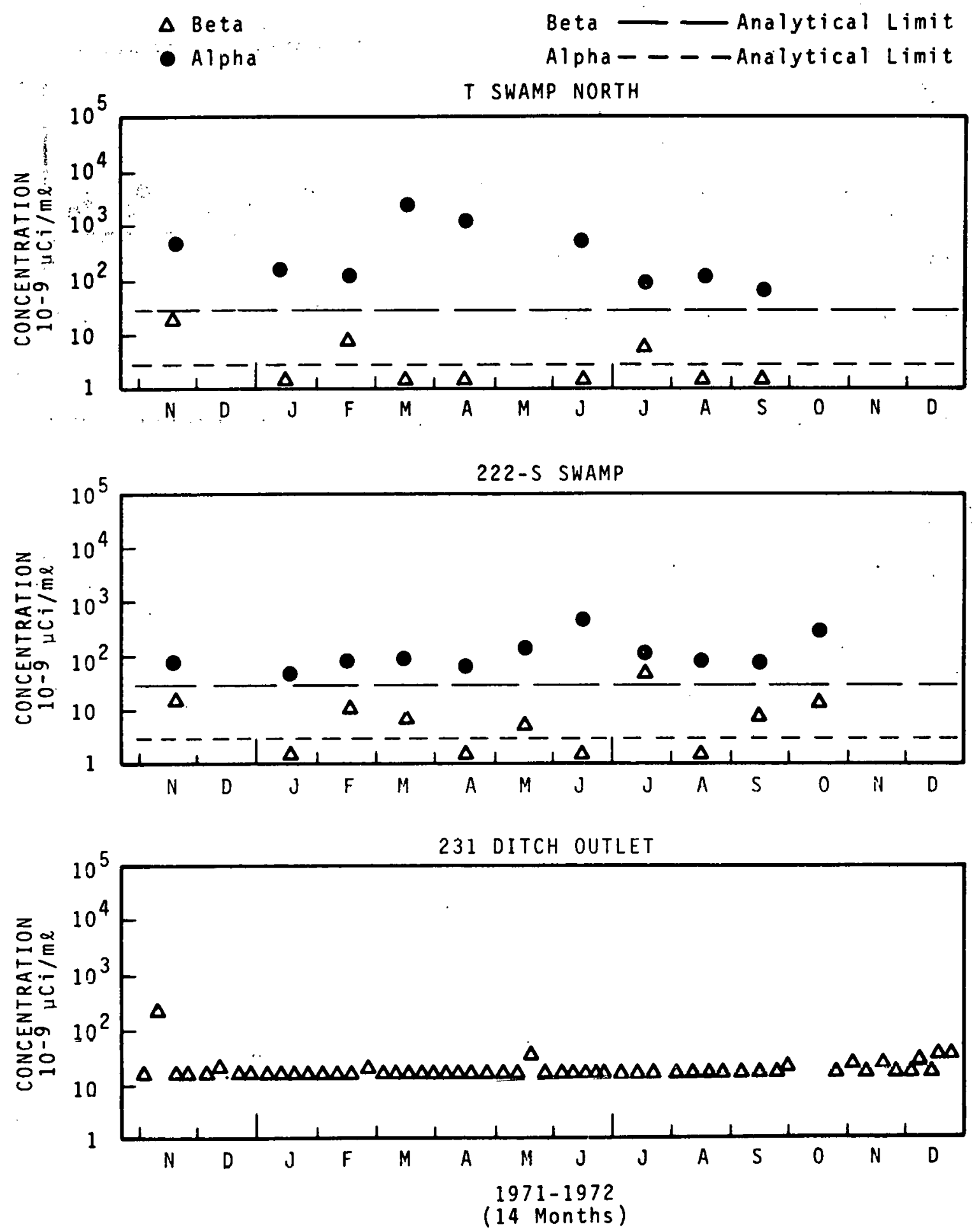
FIGURE 5

\section{RADIOACTIVITY OF WASTE WATER SAMPLES :200W, 100F AREAS}
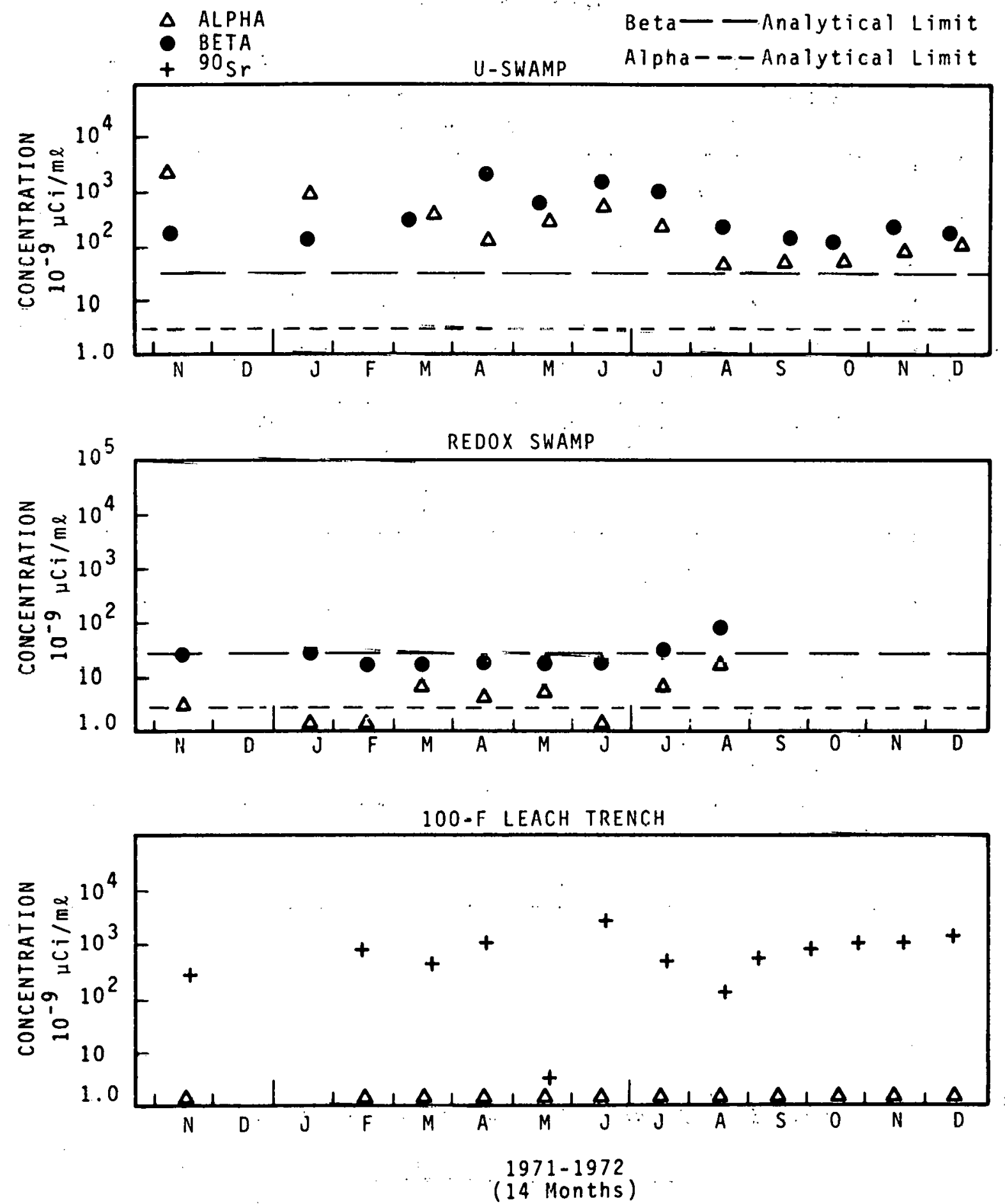
TABLE 4

GAMMA ACTIVITY IN WASTE WATER SAMPLES - 1.972

Units of $10^{-9} \mu \mathrm{Ci} / \mathrm{ml}$

\begin{tabular}{|c|c|c|c|c|c|c|c|c|c|c|}
\hline Location & Date & ${ }^{46}{ }_{S C}$ & ${ }^{51} \mathrm{cr}$ & ${ }^{60} \mathrm{co}$ & ${ }^{65} \mathrm{Zn}$ & ${ }^{95} \mathrm{ZnNb}$ & ${ }^{106}{ }_{\text {RuRh }}$ & ${ }^{137} c_{s}$ & $140_{\text {BaLa }}$ & ${ }^{144} \mathrm{CePr}$ \\
\hline Honey Hill Pond & $\begin{array}{l}6 / 2 \\
10 / 13\end{array}$ & * & * & $\stackrel{\star}{\star}$ & * & $\stackrel{*}{*}$ & * & $\star$ & * & * \\
\hline Gable Swamp & $\begin{array}{l}1 / 14 \\
4 / 7 \\
7 / 7 \\
10 / 13\end{array}$ & $\begin{array}{l}* \\
* \\
* \\
*\end{array}$ & $\begin{array}{l}* \\
* \\
*\end{array}$ & $\begin{array}{l}* \\
* \\
*\end{array}$ & $\begin{array}{l}* \\
* \\
* \\
*\end{array}$ & $\begin{array}{l}* \\
* \\
* \\
*\end{array}$ & $\begin{array}{l}* \\
* \\
* \\
*\end{array}$ & $\begin{array}{l}9.4 \\
37 . \\
90 . \\
32 .\end{array}$ & $\begin{array}{l}* \\
* \\
* \\
*\end{array}$ & $\begin{array}{l}* \\
* \\
* \\
*\end{array}$ \\
\hline B Swamp & $\begin{array}{l}1 / 14 \\
4 / 7 \\
7 / 7 \\
10 / 13\end{array}$ & $\begin{array}{l}* \\
* \\
* \\
*\end{array}$ & $\begin{array}{l}\star \\
\star \\
\star \\
\star\end{array}$ & $\begin{array}{l}* \\
* \\
* \\
*\end{array}$ & $\begin{array}{l}* \\
* \\
* \\
*\end{array}$ & $\begin{array}{c}59 . \\
* \\
* \\
*\end{array}$ & $\begin{array}{l}* \\
* \\
* \\
*\end{array}$ & $\begin{array}{l}\star \\
\star \\
\star \\
\star\end{array}$ & $\begin{array}{l}* \\
* \\
* \\
*\end{array}$ & $\begin{array}{l}* \\
* \\
* \\
*\end{array}$ \\
\hline T Swamp & $\begin{array}{l}1 / 14 \\
4 / 7 \\
7 / 7\end{array}$ & $\begin{array}{l}\star \\
\star \\
\star\end{array}$ & * & * & * & $\begin{array}{l}\star \\
\star \\
\star\end{array}$ & $\begin{array}{l}\star \\
\star \\
\star\end{array}$ & $\begin{array}{r}35 \\
*\end{array}$ & * & $\begin{array}{l}\star \\
\star \\
\star \\
\star\end{array}$ \\
\hline S Swamp & $\begin{array}{l}1 / 14 \\
4 / 7 \\
7 / 7 \\
10 / 13\end{array}$ & $\begin{array}{l}* \\
* \\
* \\
*\end{array}$ & $\begin{array}{l}\star \\
\star \\
\star \\
\star\end{array}$ & $\begin{array}{l}\star \\
\star \\
* \\
*\end{array}$ & $\begin{array}{l}\star \\
\star \\
* \\
*\end{array}$ & $\begin{array}{l}* \\
* \\
* \\
*\end{array}$ & $\begin{array}{lll} & & \\
* & & \\
* & & \\
* & & \end{array}$ & $\begin{array}{r}62 . \\
40 . \\
170 . \\
\text { * }\end{array}$ & $\begin{array}{l}* \\
* \\
*\end{array}$ & $\begin{array}{l}\star \\
\star \\
\star \\
\star\end{array}$ \\
\hline U Swamp & $\begin{array}{l}1 / 14 \\
4 / 7 \\
7 / 7 \\
10 / 13\end{array}$ & $\begin{array}{l}* \\
\text { * } \\
\text { * }\end{array}$ & $\begin{array}{l}* \\
* \\
* \\
*\end{array}$ & $\begin{array}{l}* \\
* \\
*\end{array}$ & $\begin{array}{l}* \\
* \\
*\end{array}$ & $\begin{array}{l}* \\
* \\
* \\
*\end{array}$ & $\begin{array}{l}\star \\
\star \\
\star \\
\star\end{array}$ & $220^{*}$ & $\begin{array}{l}* \\
* \\
* \\
*\end{array}$ & $\begin{array}{l}\star \\
\star \\
\star \\
\star\end{array}$ \\
\hline Redox Swamp & $\begin{array}{l}1 / 14 \\
4 / 7 \\
7 / 7\end{array}$ & $\begin{array}{l}\star \\
\star \\
*\end{array}$ & $\stackrel{\star}{*}$ & $\begin{array}{l}\star \\
\star \\
\star\end{array}$ & $\begin{array}{l}\star \\
\star \\
\star\end{array}$ & $\begin{array}{l}\star \\
\star \\
\star\end{array}$ & $\begin{array}{l}* \\
* \\
*\end{array}$ & $\begin{array}{l}\star \\
\star \\
*\end{array}$ & $\begin{array}{r}* \\
* \\
\star\end{array}$ & $\begin{array}{l}\star \\
\star \\
\star\end{array}$ \\
\hline 216 B 63 Ditch & $\begin{array}{l}1 / 14 \\
4 / 7 \\
7 / 7 \\
10 / 13\end{array}$ & $\begin{array}{l}* \\
* \\
* \\
*\end{array}$ & $\begin{array}{l}* \\
* \\
*\end{array}$ & $\begin{array}{l}\star \\
* \\
* \\
*\end{array}$ & $\begin{array}{l}* \\
* \\
* \\
*\end{array}$ & $\begin{array}{l}* \\
* \\
* \\
*\end{array}$ & $\begin{array}{l}* \\
* \\
* \\
*\end{array}$ & $\begin{array}{l}* \\
* \\
* \\
*\end{array}$ & $\begin{array}{l}* \\
* \\
* \\
*\end{array}$ & $\begin{array}{l}\star \\
\star \\
\star \\
\star\end{array}$ \\
\hline 331 Pond & $\begin{array}{l}1 / 11 \\
4 / 4 \\
7 / 11 \\
10 / 10\end{array}$ & $\begin{array}{l}* \\
* \\
* \\
*\end{array}$ & $\begin{array}{r}\star \\
\star \\
440 .\end{array}$ & $\begin{array}{l}* \\
\text { * } \\
*\end{array}$ & $\begin{array}{l}* \\
* \\
* \\
*\end{array}$ & $\begin{array}{l}* \\
* \\
* \\
*\end{array}$ & $\begin{array}{l}\star \\
\star \\
* \\
\star\end{array}$ & $\begin{array}{l}* \\
* \\
* \\
*\end{array}$ & $\begin{array}{l}* \\
* \\
* \\
*\end{array}$ & $\begin{array}{l}\star \\
\star \\
\star \\
\star\end{array}$ \\
\hline
\end{tabular}

*Less than analytical limit. 
FIGURE 6

WASTE WATER ANALYSES

300 AREA

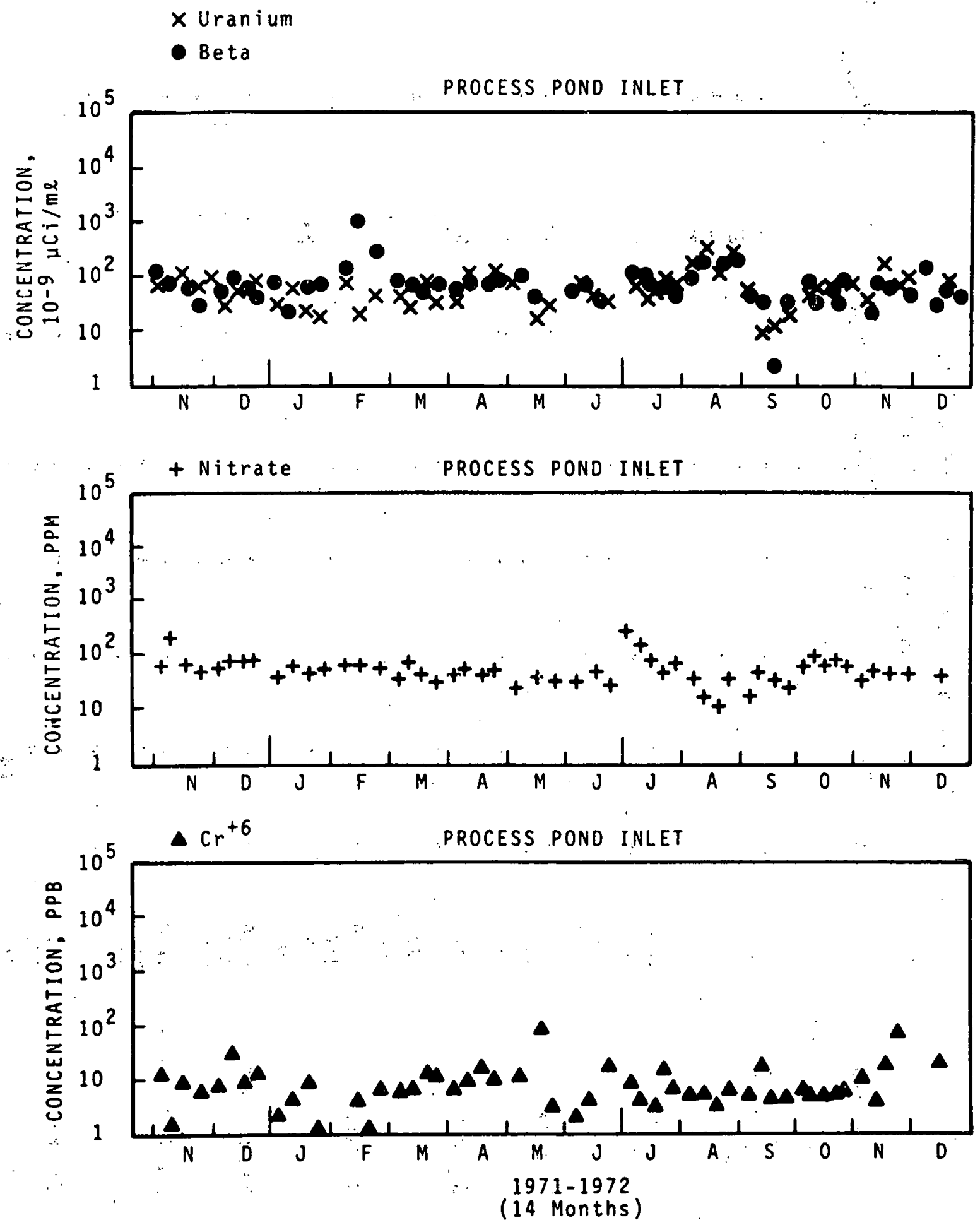


FLUORIDE ION CONCENTRATIONS IN THE 300 AREA PROCESS POND 1972

Month

January*

February

March

April

May*

June*

JuTy

August

September

october

No vember

December

Average
F-

ppm

3.0

4.5

1.7

2.2

1.1

0.9

2.2

0.1

1.2

3.1

2.8

2.9

2.1

*No analyses were made for the periods: $1 / 24 / 72$ to $2 / 7 / 72$,

$5 / 1 / 72$ to $5 / 15 / 72$, and $6 / 5 / 72$ to $6 / 12 / 72$. 
BNWL-B-278

TABLE 6

BIOLOGICAL MEASUREMENTS OF SAMPLES COLLECTED FROM THE 300 AREA LEACHING TRENCH. AND. ITS ASSOCIATED RIVER SHORELINE SEEPAGE AREA - 1972

\section{LEACHING TRENCH}

\begin{tabular}{|c|c|c|c|}
\hline Date & $\begin{array}{l}\text { Coliform } \\
\text { N/100 ml }\end{array}$ & $\begin{array}{l}\text { Enterococci } \\
\quad \mathrm{N} / 100 \mathrm{ml} \\
\end{array}$ & $\begin{array}{l}\mathrm{BOD} \\
\mathrm{mg} / \ell\end{array}$ \\
\hline $\begin{array}{l}1 / 11 \\
2 / 8 \\
3 / 14 \\
4 / 4 \\
6 / 20 \\
7 / 11 \\
8 / 8 \\
9 / 5 \\
10 / 3 \\
11 / 14 \\
12 / 12\end{array}$ & $\begin{array}{r}330,000 \\
190,000 \\
1,280,000 \\
720,000 \\
640,000 \\
1,320,000 \\
500,000 \\
3,000,000 \\
850,000 \\
320,000 \\
264,000\end{array}$ & $\begin{array}{r}3,300 \\
5,000 \\
6,500 \\
29,000 \\
7,500 \\
12,000 \\
23,000 \\
17,000 \\
33,500 \\
11,000 \\
8,000\end{array}$ & $\begin{array}{l}7.0 \\
6.7 \\
5.9 \\
2.6 \\
4.2 \\
4.0 \\
4.6 \\
3.6 \\
2.0 \\
1.9 \\
1.4\end{array}$ \\
\hline Average & 855,818 & 14,164 & 4.0 \\
\hline
\end{tabular}

R.IVER SHORELINE SEEPAGE AREA

Date

$1 / 11$

$2 / 8$

$3 / 14$

$4 / 4$

$6 / 20$

$7 / 11$

$8 / 8$

$8 / 22$

$9 / 5$

$9 / 19$

$10 / 3$

$10 / 24$

$11 / 14$

$12 / 12$

Average
Coliform

$\mathrm{N} / 100 \mathrm{ml}$

23.

2.

7.

6.

105.

250.

60.

130.

30.

98.

25.

115.

6.

8.

62.
Enterococc $i$ $\mathrm{N} / 100 \mathrm{ml}$

16.

5.

4.

10.

20.

28.

17.

25.

13.

55.

18.

148.

120.

7.

35.
BOD

$\underline{\mathrm{mg} / \ell}$

3.4

1.2

3.1

3.4

4.0

4.0

2. 8

1.2

0.45

1.9

1.6

1.6

1.4

1.8

2.3 
FIGURE 7

\section{RADIOACTIVITY OF WASTE WATER SAMPLES} 300 AREA

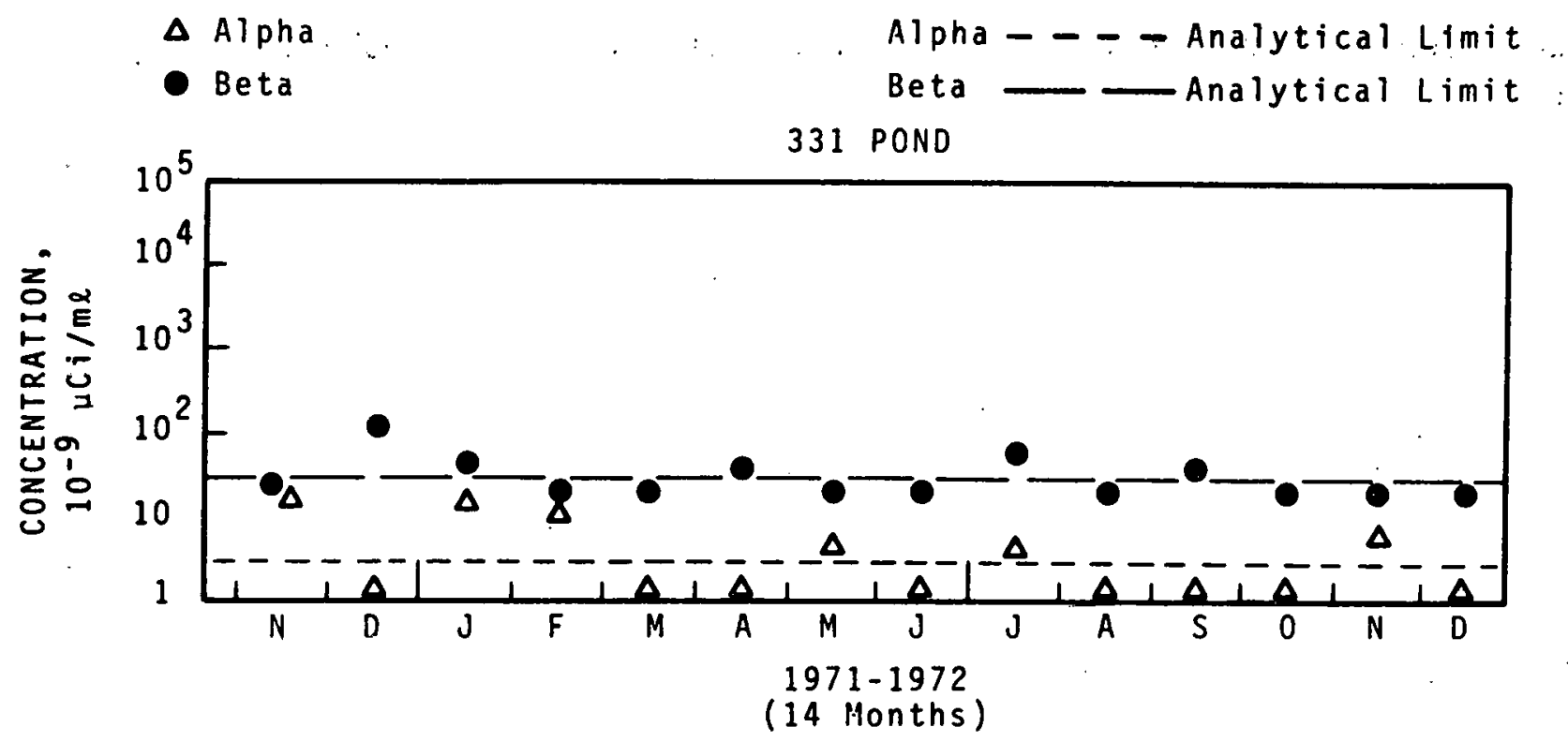


VI. GROUNDWATER

Results of the groundwater surveillance program for 1972 have been reported separately in BNWL-1737, "Radiological Status of the Groundwater Beneath the Hanford Project, January-June, 1972," and BNWL-1752, "Radiological Status of the Groundwater Beneath the Hanford Project, July-December, 1972." 


\section{BIRDS AND MAMMALS}

Migratory waterfowl utilize, as nesting places, Hanford Reservation swamps and ponds which receive low-level radioactive wastes. Ingestion of the waste or waste-contaminated vegetation may result in measurable quantities of radionuclides in the waterfowl's tissues and organs. Some resident waterfowl, other gamebirds such as pheasants, and a variety of mammals al so have access to the waste waters and potentially contaminated vegetation.

Gamma scan and strontium-90 analyses were obtained on muscle samples of. most gamebirds and mammals collected. At several locations, the liver was sampled for plutonium-239 or uranium analysis. When several birds of the same species and location were collected on the same day, muscle from one to five birds was composited for a gamma scan. The gamma scan of the composite obviated the gamma scans of the individual birds.

Waterfowl

Radionuclide concentrations in twenty-two waterfowl sampled from swamps and ponds in 1972 were generally below the concentrations recorded in 1971. Tables 7 and 8 present the average analysis results for ducks (71) and geese (32) sampled from the Columbia River in the vicinity of the reactor areas. The average Cs-137 was much lower in the river waterfowl than the swamp and pond waterfowl indicating that the river waterfowl, most subject to public hunting do not frequent the 200 Area swamps and ponds.

\section{Pheasants}

No unusual radionuclide concentrations were detected in twentyfour pheasants. Cs-137, Sr-90, and $\mathrm{Zn-65}$ concentrations were similar to the values observed in geese.

Deer

The deer population sampled is assumed to be resident on the Hanford plant; relaxation of access control of sportsmen on Wahluke Slope increases the probability of hunters bagging Hanford deer. 
VII. BIRDS AND MAMMALS (Continued)

Deer (Continued)

Deer were sampled as part of the environmental sampling program in January, September, and November. Generally, the radionuclide concentrations detected in muscle tissue (Table 9) were comparable to 1971 samples. Cs-137 concentration in the muscle of the November deer was higher than any deer sample of 1971 but less than deer samples of 1970. This deer was possibly using the 200 Area waste water ponds as a source of water. Sr-90 concentrations observed in the Hanford deer are similar to the concentrations in deer from other parts of the country and are attributed to fallout.

\section{Small Mamma 1s}

Sampling of mice and rabbits (Table 10) was conducted near liquid waste trenches and ponds in the 100, 200, and 300 Areas. The results serve as an indicator of potential transport of radioactivity away from waste sites by mammals even though no direct pathway to man of radiation exposure from such mammals is bel ieved to exist. Radionuclide concentrations in mammals collected in 1972 were generally lower than in 1971. Mice collected from the vicinity of the $100 \mathrm{~N}$ trench continued to show radionuclide concentrations orders of magnitude above specimens from other Hanford locations, probably as a result of ingestion of water from 100-N trench. However, a mouse trapped at the 100- $\mathrm{F}$ Leach Trench contained the highest $\mathrm{Sr}-90$ concentration.

Radionuclide concentrations in rabbits were somewhat lower in 1972 except for Cs-137 which was notably higher in a rabbit taken near 222-S Swamp.

Coyote

A road-killed coyote was sampled in January (Table 9). Radionuclide concentrations were generally higher than deer but less than the mice and rabbits. 
TABLE 7

AVERAGE RADIONUCLIDE CONCENTRATIONS IN MUSCLE OF GAMEBIRDS - 1972 Units of $10^{-6}{ }_{\mu \mathrm{Ci}} / \mathrm{gm}$ (wet weight)

\begin{tabular}{|c|c|c|c|c|c|c|c|c|}
\hline Location & Spectes & $\begin{array}{l}\text { No. of } \\
\text { Samples }\end{array}$ & ${ }^{58} \mathrm{Co}$ & ${ }^{60} \mathrm{Co}_{\mathrm{O}}$ & ${ }^{65} \mathrm{Zn}$ & ${ }^{90} \mathrm{Sr}$ & ${ }^{137} \mathrm{Cs}_{\mathrm{S}}$ & ${ }^{141} \mathrm{Ce}$ \\
\hline Analytical Limit & & & 0.15 & 0.15 & 0.20 & 0.002 & 0.1 & \\
\hline U Swamp & Ducks & 2 & * & * & * & 0.006 & 27. & * \\
\hline Redox Swamp & Ducks & 2 & * & * & * & 0.054 & 3.1 & * \\
\hline Gable Swamp & Ducks & 4 & * & * & $\stackrel{\star}{.}$ & 0.003 & 26. & * \\
\hline B Swamp & Ducks & 4 & * & * & 0.11 & 0.003 & 3.3 & * \\
\hline 300 Pond & Ducks & 5 & * & * & * & * & * & * \\
\hline 100-F Trench & Ducks & 3 & * & $\star$ & 0.14 & 0.11 & 0.14 & * \\
\hline T Swamp & Ducks & 1. & * & 0.20 & 0.40 & 0.003 & 70. & * \\
\hline Honey Hill Pond & Ducks & 1 & * & * & * & * & 4.2 & * \\
\hline Columbia River & Ducks & 71 & * & * & 0.096 & 0.003 & 0.070 & * \\
\hline Columbia River & Geese & 32 & * & * & 0.079 & 0.003 & 0.11 & * \\
\hline 100 Areas & Pheasants & 24 & * & * & .073 & 0.003 & 0.084 & * \\
\hline
\end{tabular}

*Less than the analytical limit. 
TABLE 8

AVERAGE CONCENTRATIONS OF SELECTED RADIONUCLIDES IN THE LIVERS OF WATERFOWL SAMPLES IN THE HANFORD ENVIRONS - 1972

Units of $10^{-6} \mu \mathrm{Ci} / \mathrm{gm}$ (wet weight)

Location

Analytical Limit

300 Pond

100-F Trench

Honey Hill Pond

U Swamp
No. of Samples

$\begin{array}{ccc} & 0.016 & 0.05 \\ 5 & 0.046 & \star \\ 2 & \star & \star \\ 1 & & 0.24\end{array}$

*Less than the analytical limit.

No entry indicates no analysis was performed.

\section{TABLE 9}

CONCENTRATION OPF SFVERAL RADIONUCLIDES IN DEER AND COYOTE - 1972 Units of $10^{-6} \mu \mathrm{Ci} / \mathrm{gm}$ (wet woight)

Location Date Tissue $\underline{{ }^{65} \mathrm{Zn}} \quad \underline{{ }^{90} \mathrm{Sr}} \quad \underline{{ }^{137} \mathrm{Cs}} \quad{ }^{239} \underline{\mathrm{Pu}}$

Deer

Rt. $11 \mathrm{~A}, \mathrm{Mi} \cdot 1.5 \quad 1 / 20$

Muscle *

*

0.48

0.048

Rt. 11A, Mi. $1.5 \quad 1 / 20$

Bone

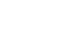

Muscle

0.081

0.48

$\star$

0.009

300 Area

$9 / 28$

300 Area

$9 / 28$

Liver

$11 / 7$

Muscle

0.054

$\star \quad 0.071$

0.00008

Rt. 4S, Mi. 13

$11 / 7$

Liver

* $\quad 0.24$

0.00005

Coyote

$\begin{array}{lllllll}\text { Rt. } 4 S, M i .20 & 1 / 20 & \text { Muscle } & * & * & 0.18 & \\ \text { Rt. } 4 S, \text { Mi. } 20 & 1 / 20 & \text { Liver } & .0 .28 & 0.009 & 0.11 & 0.0001\end{array}$

*Less than the analytical limit.

No entry indicates no analysis was performed. 


\section{TABLE 10}

CONCENTRATIONS OF SEVERAL RADIONUCLIDES IN SMALL ANIMALS Units of $10^{-6} \mu \mathrm{Ci} / \mathrm{gm}$ (in muscle)

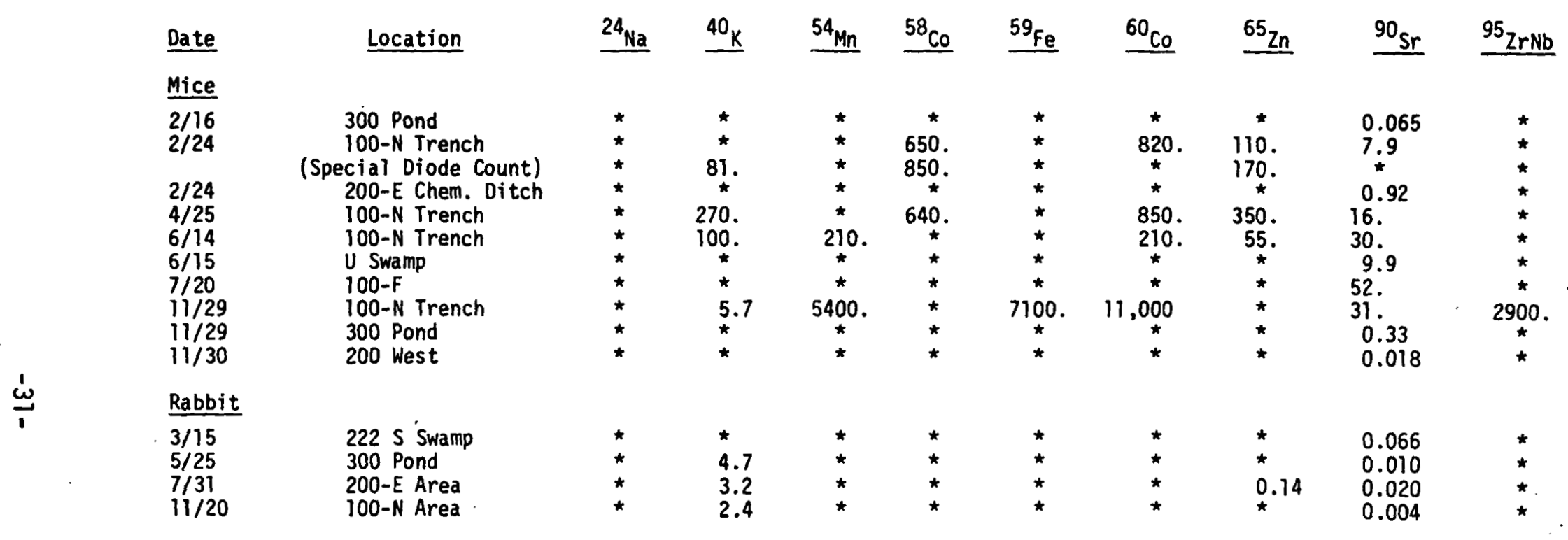

\#Less than the analytical limit. 
TABLE 10 (Continued)

CONCENTRATIONS OF SELECTED RADIONUCLIDES IN SMAL: ANIMALS

Units of $0^{-6} \mu \mathrm{Ci} / \mathrm{gm}$ (in muscle)

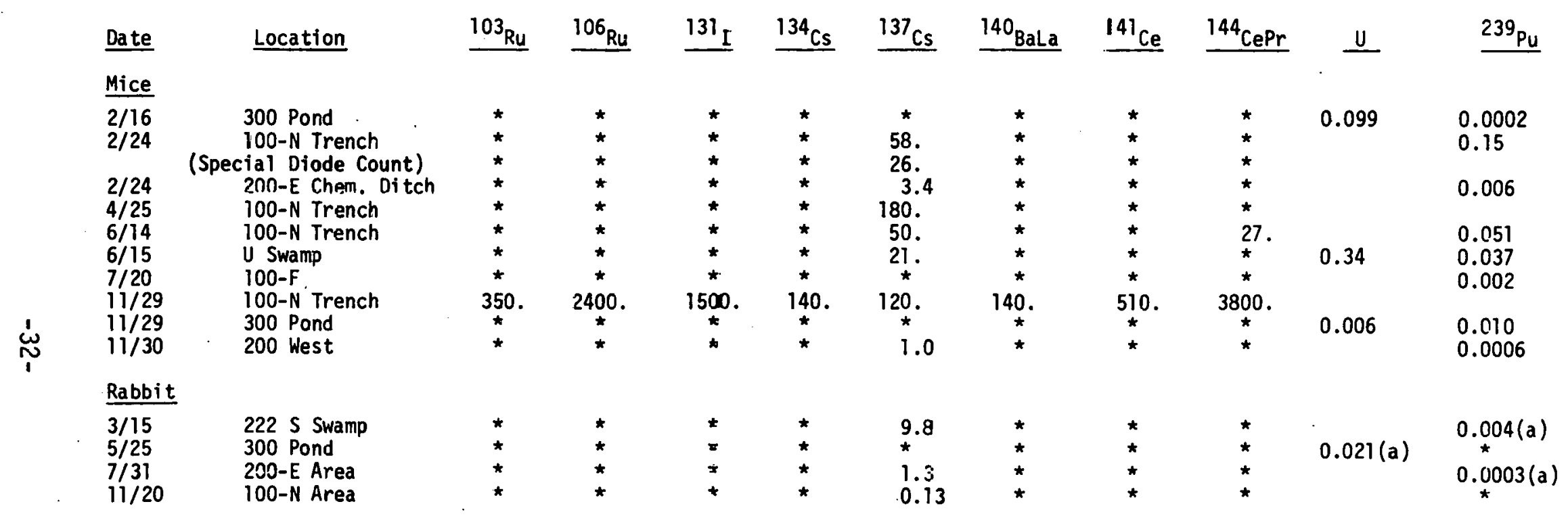

(a) Concentration in liver tissue.

* Less than the analytical limit.

No entry indicates no analysis was performed. 


\section{AIRBORNE RADIOACTIVITY}

Results of routine sampling of the atmosphere for radioactivity at 18 locations within the Hanford reservation (Map 4) are presented in Figures 8 through 18. For comparison, data from 18 off-site locations (Map 5) are included in the following discussion. Sampling for chemical pollutants and particulates in the atmosphere is conducted and reported by the Hanford Environmental Health Foundation.

The sampling equipment, sheltered in small buildings, draws air at a flow rate of $2.5 \mathrm{~m}^{3} / \mathrm{hr}(1.5 \mathrm{cfm})$ through $\mathrm{HV}-70$ or Acropor filter paper, and then through activated charcoal cartridges for radioiodine collection. The normal sampling period was one week through. June, but several of the sampling locations were changed to bi-weekly after June. "Total beta" represents the gross beta activity (Sr-Y-90 calibration), and "total alpha" represents the gross alpha activity ( $\mathrm{Pu}-239 \mathrm{calibration)}$ of particulates collected on the filter paper during the sampling period.

Table II shows the annual average I-131, particulate total beta, and particulate total alpha activity in air at various locations for 1968-1972. Results of gamma scans, gross alpha, and gross beta analyses on selected environmental air filters are presented in Tables 12 and 13 . Concentration Guides shown are taken from AECM 0524, Annex A, Table II, Column 1, and are applicable to individuals not occupationaliy exposed.

\section{A. Iodine-131}

Concentrations of $\mathrm{I}-131$ in the atmosphere during 1972 averaged less than the analytical 1 imit of $2 \times 10^{-14} \mu \mathrm{Ci} / \mathrm{ml}$ for on-site locations and off-site locations. The maximum individual weekly average concentration measured during this reporting period was $10^{-13} \mu \mathrm{Ci} / \mathrm{ml}$, noted in May at 300 Area. For comparison, the maximum I-131 concentration measured during 1971 was $8 \times 10^{-13} \mu \mathrm{Ci} / \mathrm{ml}$ at 300 Area.

\section{B. Total Beta}

During 1972, environmental air filters from 18 on-site locations and 18 off-site locations were examined weekly or biweekly for particulate total beta activity. Tables 11 and 12 show the average particulate total beta activity in air at various locations. Airborne radio- 
VIII.AIRBORNE RADIOACTIVITY (Cont inued)

\section{B. Total Beta (Continued)}

activity measurements were discontinued at $100-\mathrm{H}$ in December, after a private manufacturing venture had been completed.

Beta activity has, in the past, been characterized by seasonal peaking about mid-year. This was not as apparent in 1972 as in previous years as shown in Figures 8-14. Concentrations in and near the 100 Areas were quite uniform during any given period, indicating the lack of a significant source at the Reactor Areas. This was not true of the 200 Areas, notably the East North Center (ENC) locations which are affected by a dose in 200-East Area waste disposal operation. The maximum measured concentrations, $3 \times 10^{-11} \mu \mathrm{Ci} / \mathrm{ml}$ (total beta), occurred in October at the 200 ENC location. Annual average concentrations were similar to 1971 , ranging from $10^{-13}$ to $2 \times 10^{-13} \mu \mathrm{Ci} / \mathrm{ml}$ in the 100 Areas and from $2 \times 10^{-13}$ to $3 \times 10^{-13} \mu \mathrm{Ci} / \mathrm{ml}$ in the 200 Areas except for $200 \mathrm{ENC}$ which averaged $4.6 \times 10^{-12} \mu \mathrm{Ci} / \mathrm{ml}$.

The maximum measured concentration at an off-site location, $3.6 \times 10^{-12}$ $\mu \mathrm{Ci} / \mathrm{ml}$, occurred in May at McNary. Annual average concentrations at off-site locations ranged trom abuul $10^{-11}$ to $3 \times 10^{-11} \mu \mathrm{r.i} / \mathrm{ml}$.

\section{Total Alpha}

The weekly filters analyzed for beta-gamma emitting radionuclides were also analyzed for alpha activity. These data are presented in Tables 11 and 12. Alpha counting of the filters was normally performed after seven days to allow for the decay of short-lived activity from naturally-occurring radon daughters. Total alpha concentrations during 1972 averaged about $2 \times 10^{-15} \mu \mathrm{Ci} / \mathrm{ml}$ at most on-site locations compared to $4 \times 10^{-15}$ in 1971 . The highest annual average was $4 \times 10^{-15} \mu \mathrm{Ci} / \mathrm{ml}$ at ENC compared to $2.4 \times 10^{-14} \mu \mathrm{Ci} / \mathrm{ml}$ at ENC for 1971. Analysis of composite samples (Table 13) a 11 showed less than $10^{-16} \mu \mathrm{Ci} / \mathrm{ml}$ of plutonium.

D. Other Radionuclides

Gamma spectrum analysis was performed on a number of monthly composites of selected air filters. Quarterly analysis for $5 r-90$ and 
BNWL-B-278

\section{VIII.AIRBORNE RADIOACTIVITY (Continued)}

D. Other Radionuclides (Continued)

Pu-239 of the composites was a7so performed. Table 13 presents the results of these special analyses. At most sampling locations, average concentrations of gamma emitters for 1972 were lower than 1971. Average gamma emitter concentrations in Active Area \#5, comprised of 100-N, 100-K, and 100-D Areas, were somewhat above the 1971 average as was 200 ENC. A1so, Ba-La-140 was higher than in 1971 primarily in the last quarter of the year. 


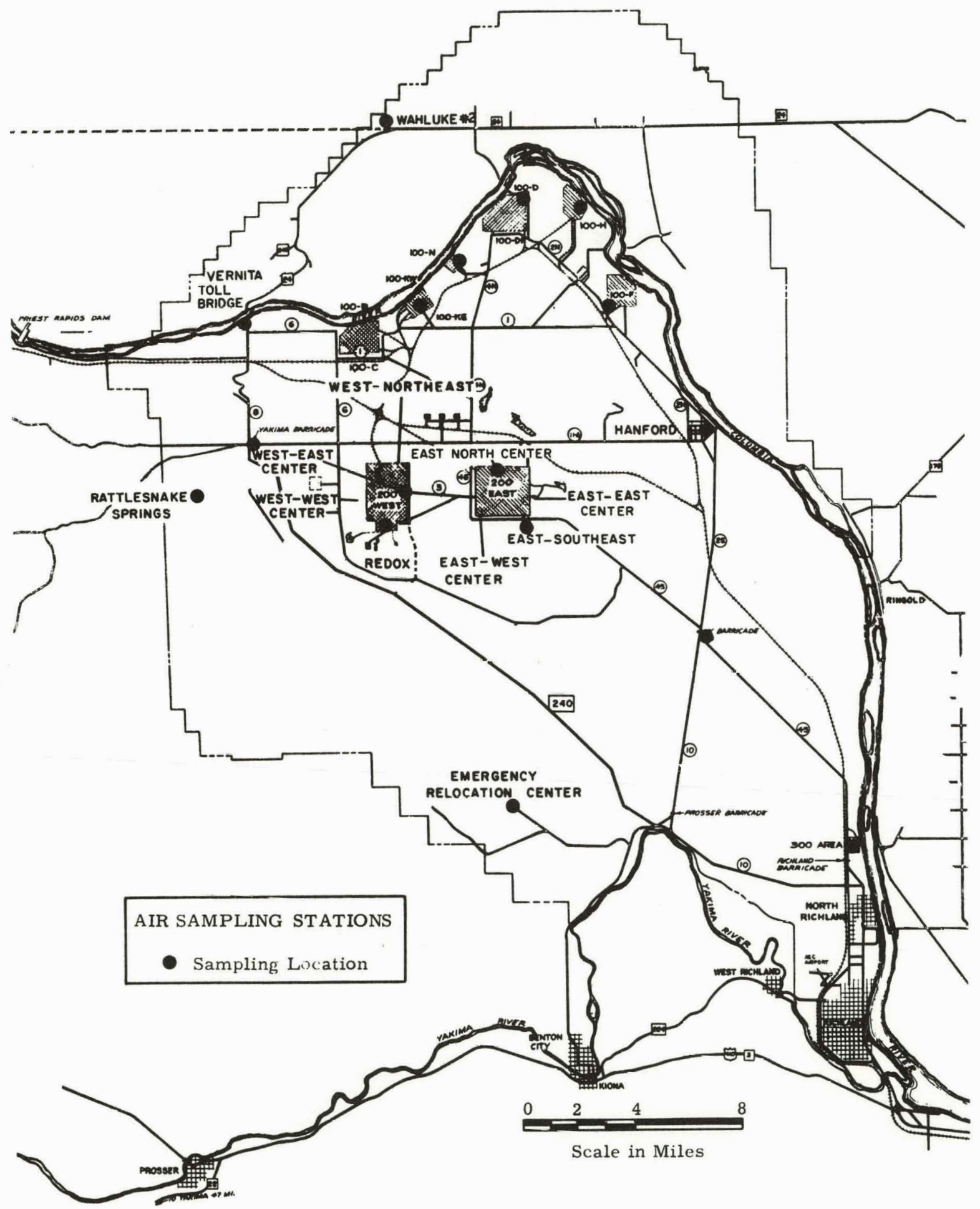


MAP 5

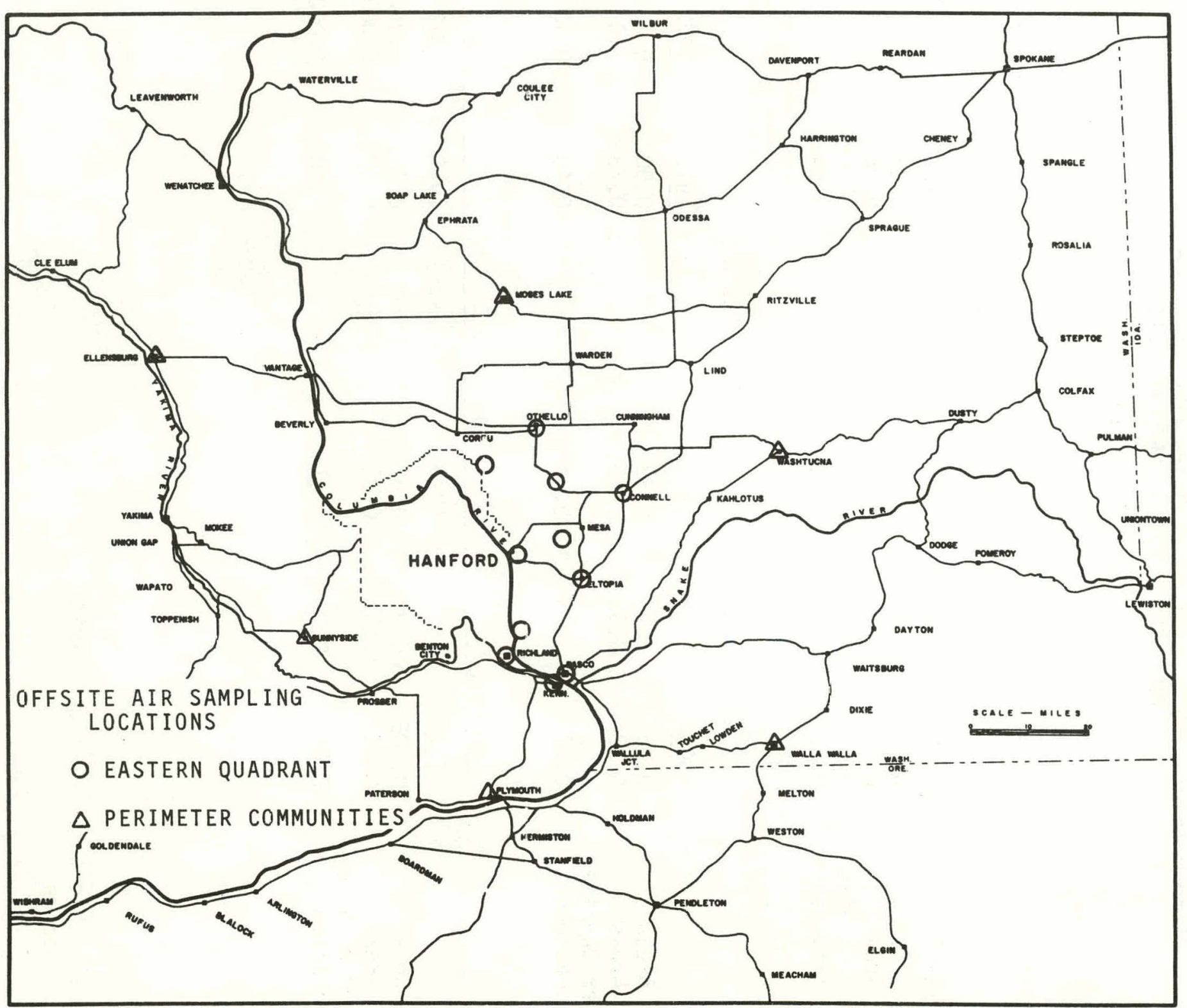

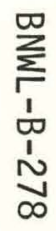


BNWL-B-278

TABLE 11

AVERAGE I-131, PARTICULATE TOTAL BETA, AND PARTICULATE TOTAL ALPHA CONCENTRATIONS IN THE ATMOSPHERE

$$
\text { Units of } 10^{-12} \mu \mathrm{Ci} / \mathrm{ml}
$$

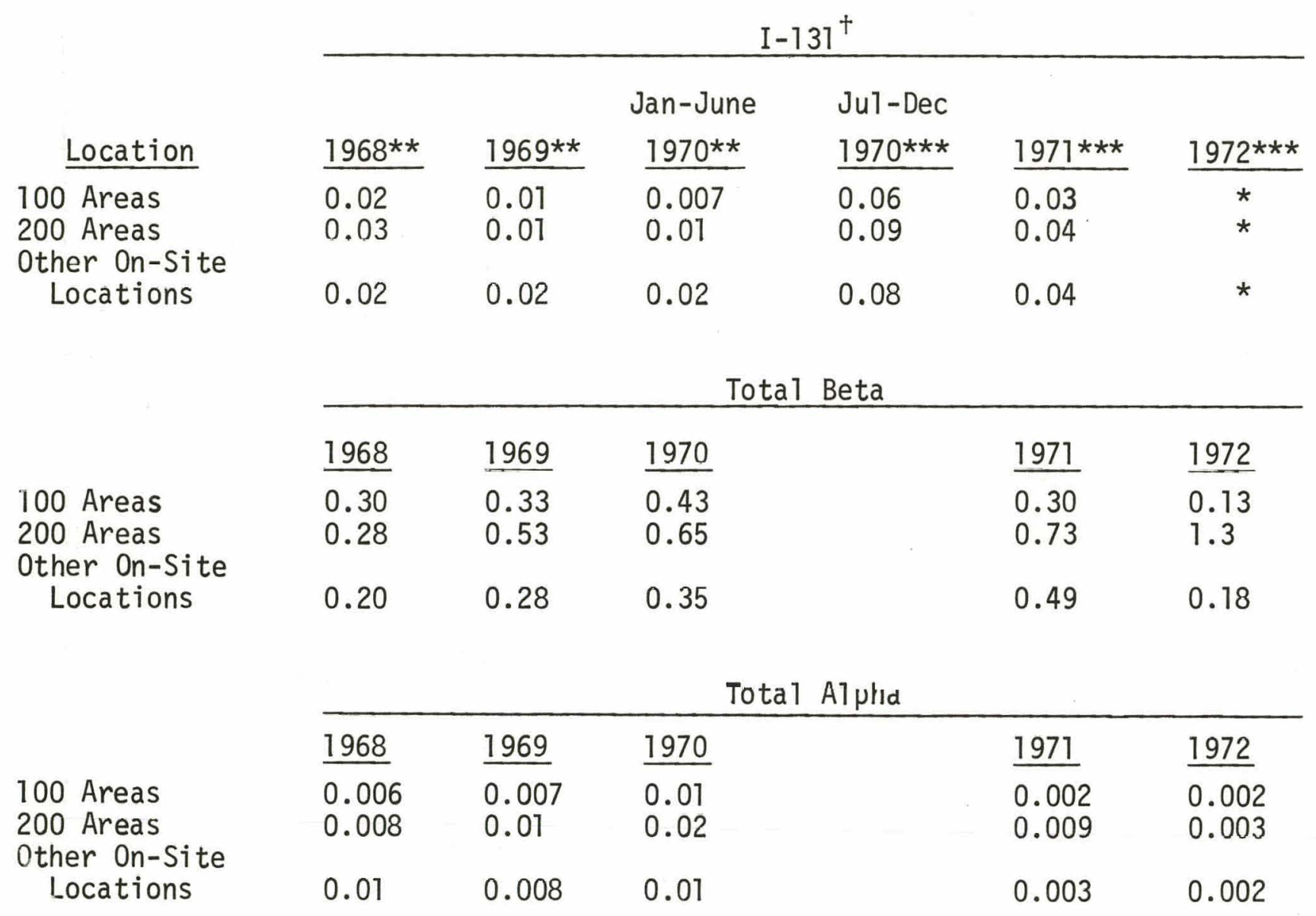

\footnotetext{
*Less than the analytical limit.

** Scrubbers

$* * *$ Charcoal Cartridges

Tost restrictive Concentration Guide $-1 \times 10^{-10} \mu \mathrm{Ci} / \mathrm{ml}$
} 
TABLE 12

I-131, PARTICULATE TJTAL BETA, AND PARTICULATE TOTAL ALPHA IN THE ATMOSPHERE - 1972 Units of $10^{-12} \mu \mathrm{Ci} / \mathrm{ml}$

On-Site

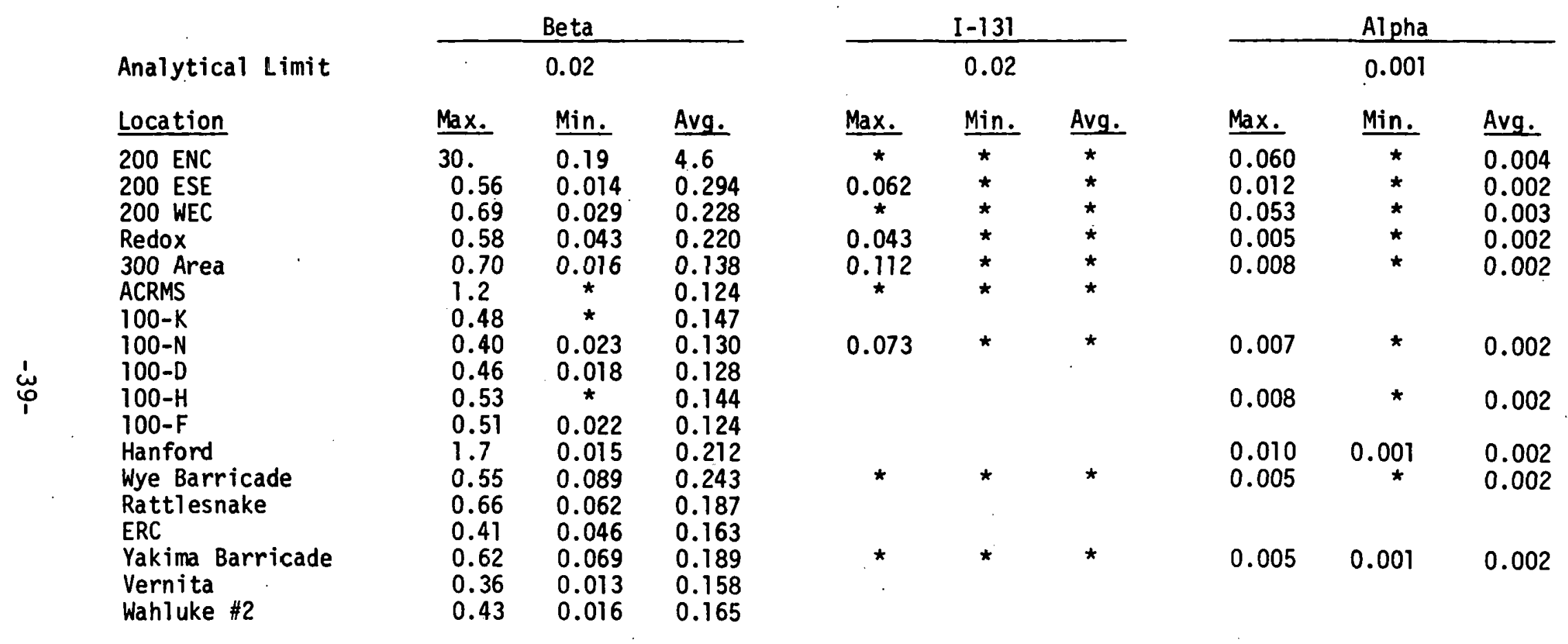

*Less than the analytical limit.

No entry indicates no anlys is vas performed. 
TABLE 12 (Continued)

I-131, PARTICULATE TOTAL BETA, AND PAF:TICULATE TOTAL ALPHA IN THE ATMOSPHERE - 1972 Units of $10^{-12} \mu \mathrm{Ci} / \mathrm{mr}$.

\section{Off-Site}

$\begin{array}{ll} & \\ & \text { Analytical Limit } \\ \text { Location } \\ \text { Byers Landing } \\ \text { Ringold } \\ \text { Richland } \\ \text { Pasco } \\ \text { Kennewick } \\ \text { Eltopia } \\ \text { Walla Walla } \\ \text { McNary } \\ \text { Ellensburg } \\ \text { Sunnyside } \\ \text { Othe1lo } \\ \text { Connell } \\ \text { Berg Ranch } \\ \text { Wahluke Wm. } \\ \text { New Moon } \\ \text { Moses Lake } \\ \text { Washtucna } \\ \text { Benton City } \\ \text { P }\end{array}$

Beta

0.02

\begin{tabular}{ccc} 
Max. & Min. & Avg. \\
\hline 0.45 & 0.048 & 0.163 \\
0.57 & 0.030 & 0.183 \\
0.43 & 0.042 & 0.170 \\
0.43 & 0.037 & 0.166 \\
0.44 & 0.069 & 0.156 \\
0.40 & 0.035 & 0.147 \\
0.45 & 0.021 & 0.150 \\
3.6 & 0.042 & 0.286 \\
0.20 & 0.021 & 0.102 \\
0.37 & $\star$ & 0.121 \\
0.44 & 0.032 & 0.176 \\
0.58 & $\star$ & 0.163 \\
0.92 & 0.030 & 0.215 \\
0.50 & 0.013 & 0.143 \\
0.46 & 0.026 & 0.157 \\
0.35 & 0.027 & 0.141 \\
0.42 & 0.058 & 0.155 \\
0.41 & 0.045 & 0.174
\end{tabular}

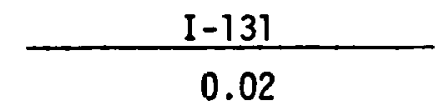

Max. Min. Avg. 0.071 0.026

$$
0.050
$$
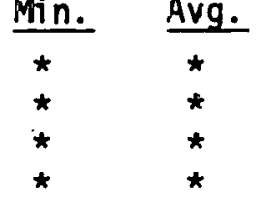

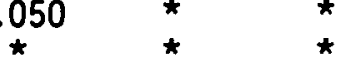

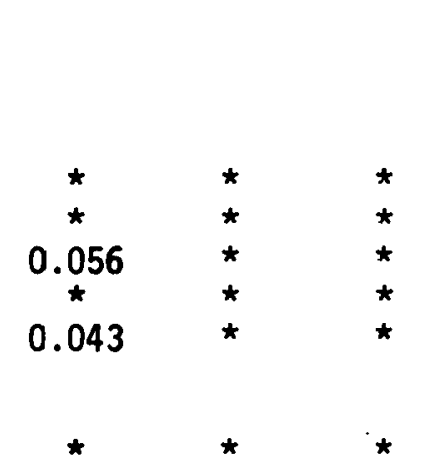

\begin{tabular}{ccc}
\multicolumn{3}{c}{ Alpha } \\
\hline \multicolumn{3}{c}{0.001} \\
Max. & Min. & Avg. \\
\hline 0.006 & $\star$ & 0.002 \\
0.006 & 0.001 & 0.002 \\
0.005 & 0.001 & 0.002 \\
0.005 & $\star$ & 0.002 \\
& & \\
0.004 & $\star$ & 0.001 \\
0.006 & 0.001 & 0.002
\end{tabular}

0.006 * 0.002

0.006 * 0.002

$0.005 \quad$ * 0.002

*Less than the analytical limit.

No entry indicates no analysis was performed. 
TABLE 13

AVERAGE CONCENTRATIONS OF GAMMA EMITTERS AND PLUTONIUM

$$
\text { ON SELECTED AIR FILTERS - } 1972
$$

$$
\text { Units of } 10^{-12} \mu \mathrm{Ci} / \mathrm{ml}
$$

$\frac{{ }^{90} \mathrm{Sr}}{200} \frac{{ }^{95} \mathrm{ZrNb}}{1000} \frac{106_{\mathrm{RURh}}}{200} \frac{134 \mathrm{Cs}}{400} \cdot \frac{13 \mathrm{Cs}^{-137 \mathrm{~m}_{\mathrm{Ba}}}}{500} \cdot \frac{140_{\mathrm{BaLa}}}{1000} \frac{144 \mathrm{CePr}}{200} \cdot \frac{\begin{array}{c}\text { Total } \\ \mathrm{Pu}\end{array}}{1}$

\section{Active Areas}

Active Area \#1

Active Area \#2

0.021

0.003

0.003

0.68

$\star 0.80$

0.06

3.1

0.61

* $\quad 0.00004$

Active Area \#3

0.001

0.044

0.024

0.16

$\star 0.003$

$\star 0.002$

0.049

0.027

0.24

0.007

0.004

0.053

0.047

0.035

0.042

0.0002

Active Area \#5

\section{Inner Ring}

\begin{tabular}{ll} 
& Inner SW Quadrant \\
$\dot{ }$ & Inner NW Quadrant \\
\hline & Inner East Quadrant
\end{tabular}

0.002

0.032

0.26

0.030

0.22

0.001
0.001

0.036

0.27

$\star 0.002$
$\star 0.001$

$\star 0.001$

$\star 0.002$
0.005

0.005
0.012

0.13

0.055

\section{Eastern Quadrant}

Inner NE Quadrant

$\star 0.0008$

0.001

0.035

0.027

0.24

0.26

$\star 0.0009$

$\star 0.0007$

$\star 0.001$

*

0.037

0.038

0.032

0.042

0.00003

Perimeter Communities

Outer NE Quadrant

Outer SE Quadrart

0.001

$\star 0.0008$

0.022

0.17

0.026

0.17
0.24

$\star 0.004$

$* 0.003$

Outer West Quadrant

0.001

0.020

0.20

$\star 0.002$

\section{$\star 0.002$ \\ $\star 0.001$}

$\star 0.0007$

0.14
0.028

0.047

0.061

$\star 0.038$

0.00002

0.00002

0.00003 
FIGURE 8

TOTAL BETA ACTIVITY IN THE ATMOSPHERE

100-AREAS AND VICINITY

- Beta

- Anaiytical Limit

VERNITA BRIDGE

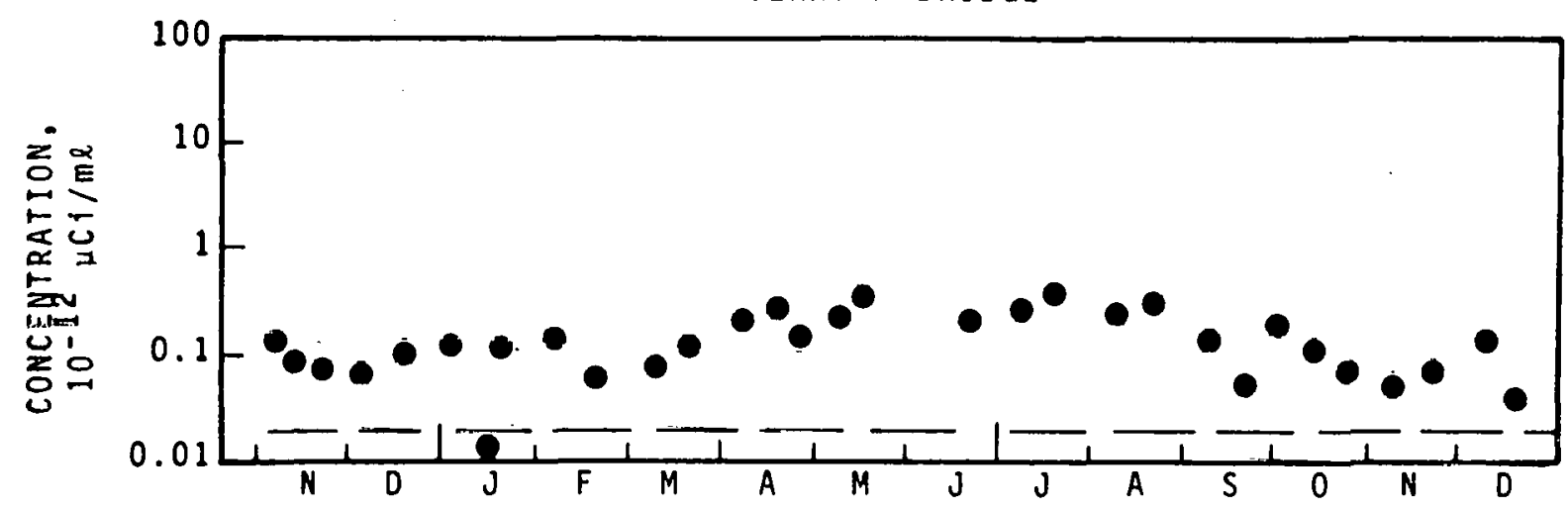

100-K AREA
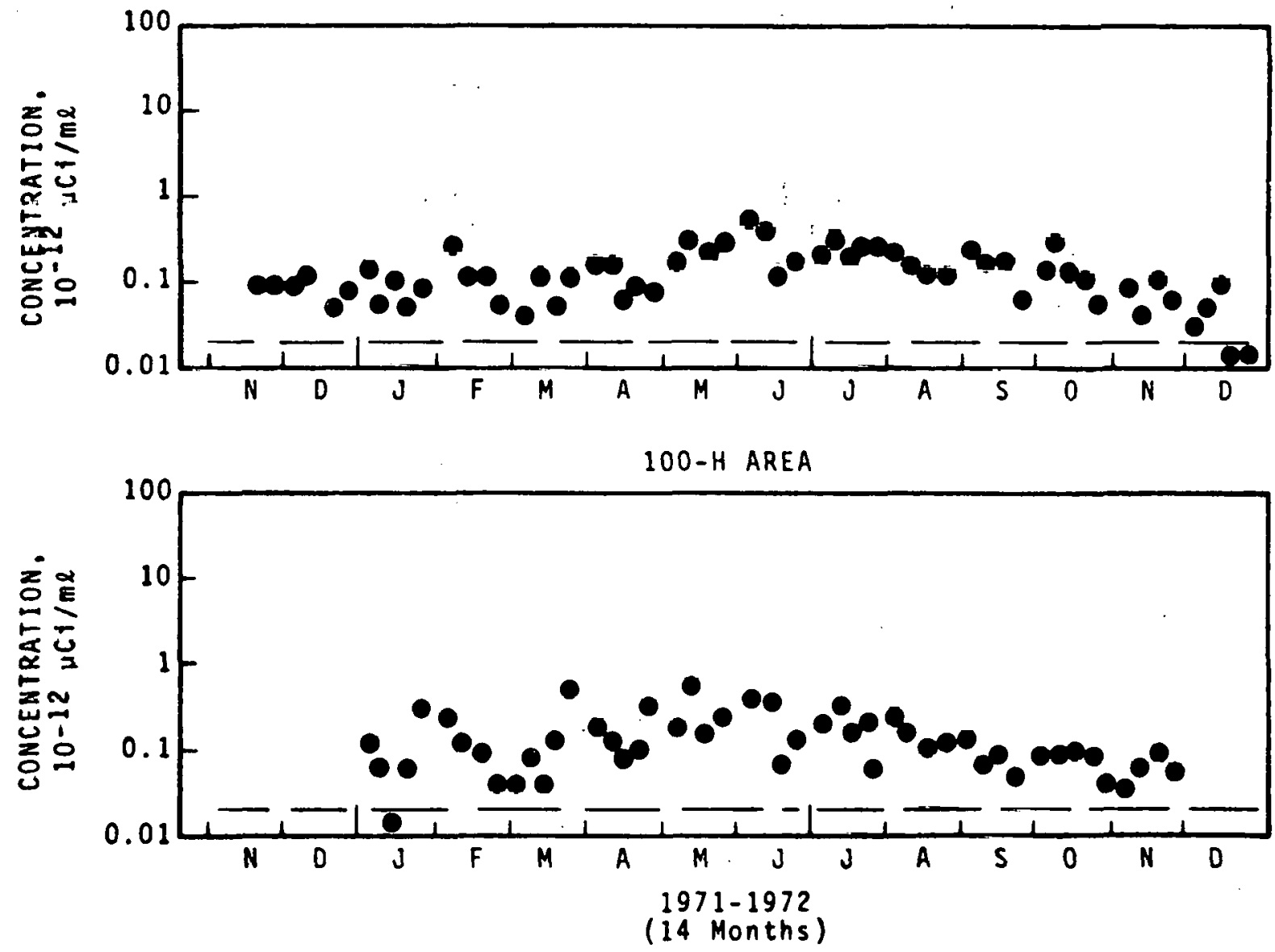
FIGURE 9

TOTAL BETA ACTIVITY IN THE ATMOSPHERE

100-AREAS AND VICINITY

- Beta

- Analytical Limit

100-N AREA
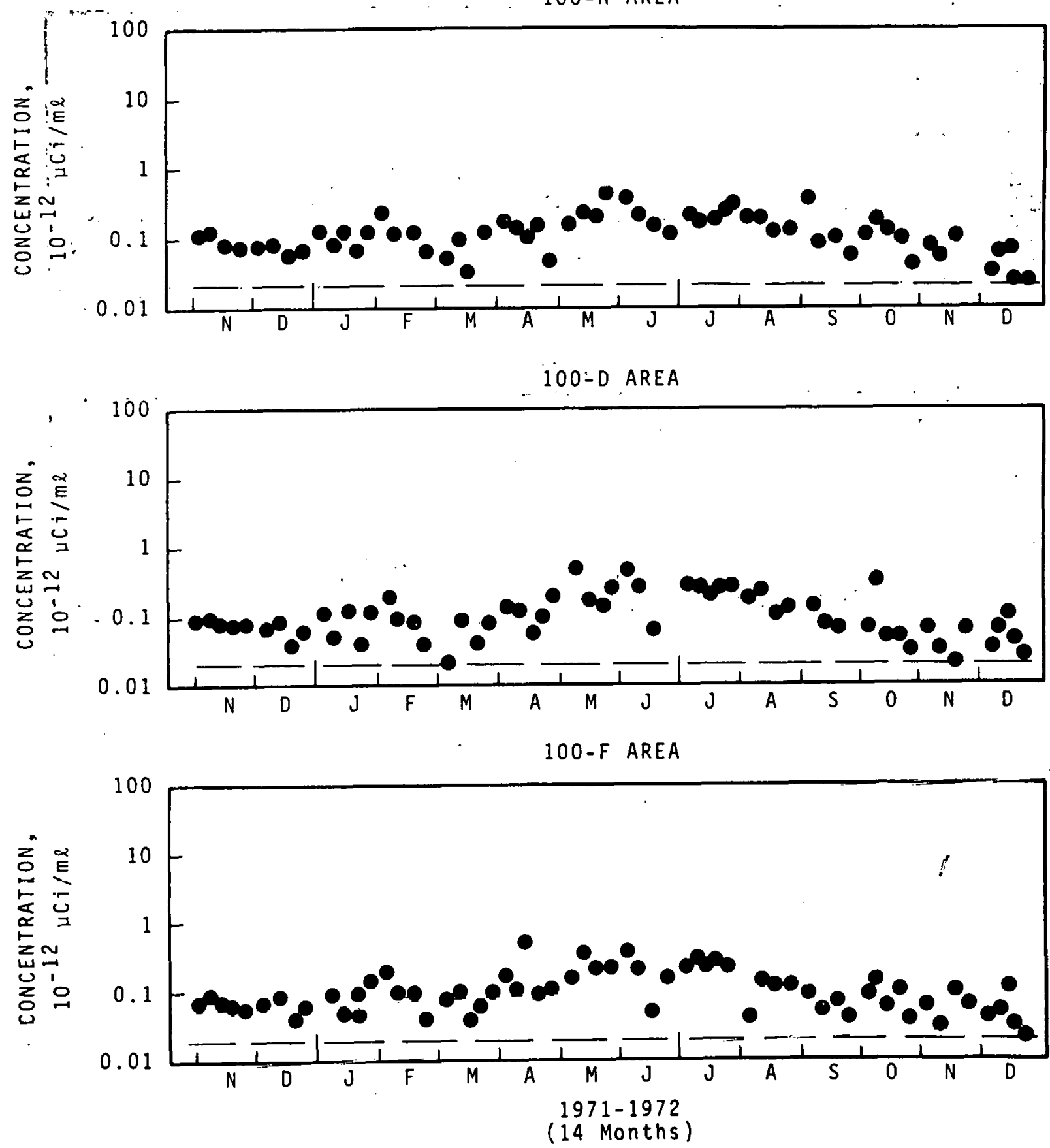
FIGURE 10

TOTAL BETA ACTIVITY IN THE ATMOSPHERE

- Beta

$$
\text { Beta - Analytical Limit }
$$

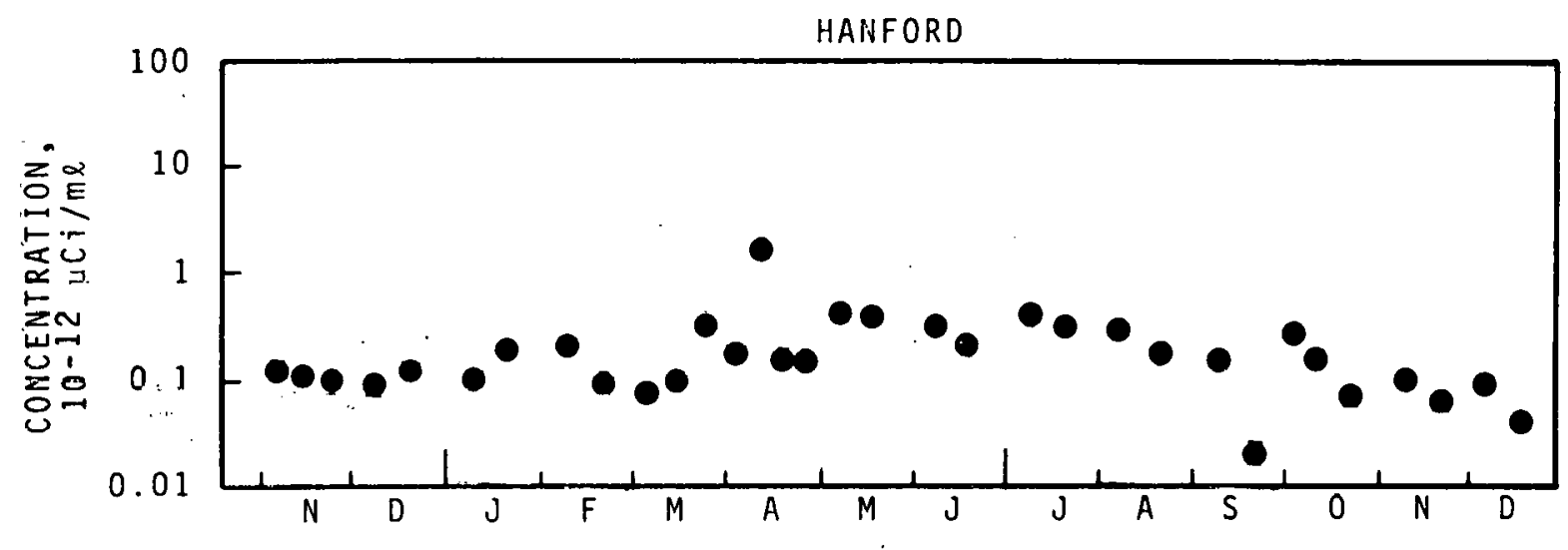

YAKIMA BARRICADE

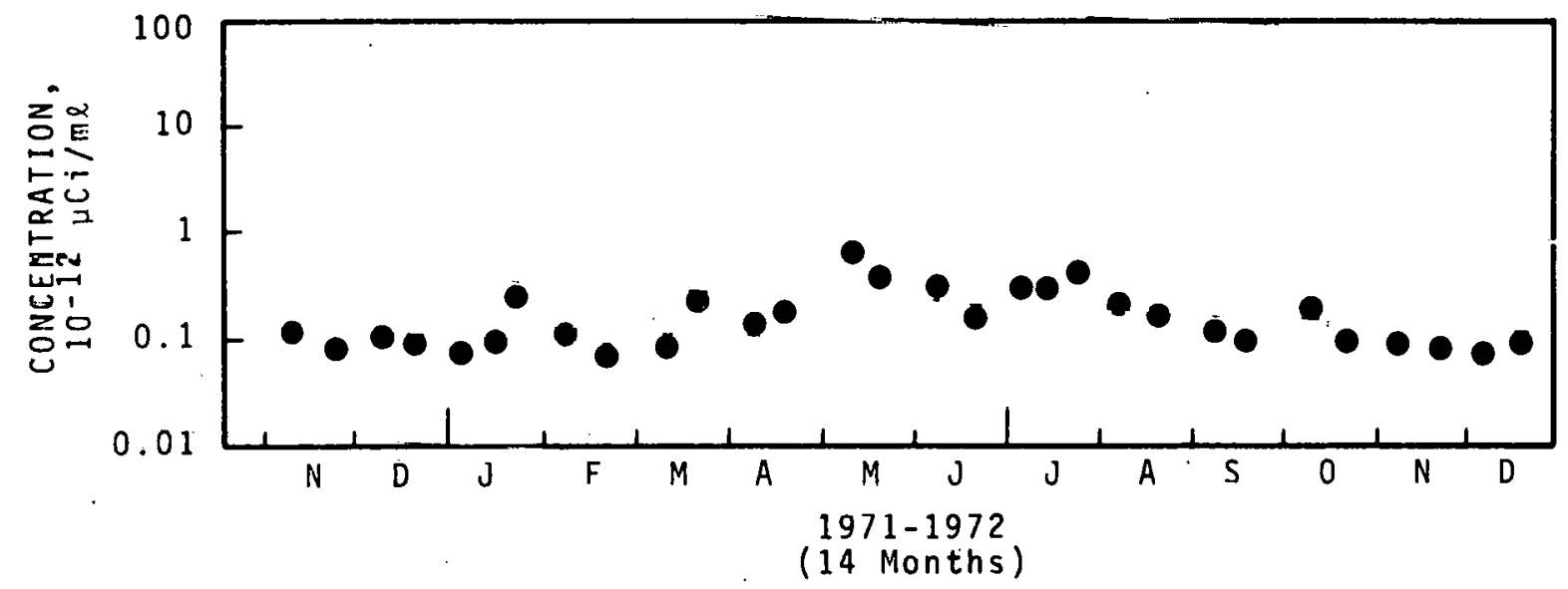




\section{FIGURE $"\rceil 1$}

TOTAL BETA ACTIVITY IN THE ATMOSPHERE 200 AREAS

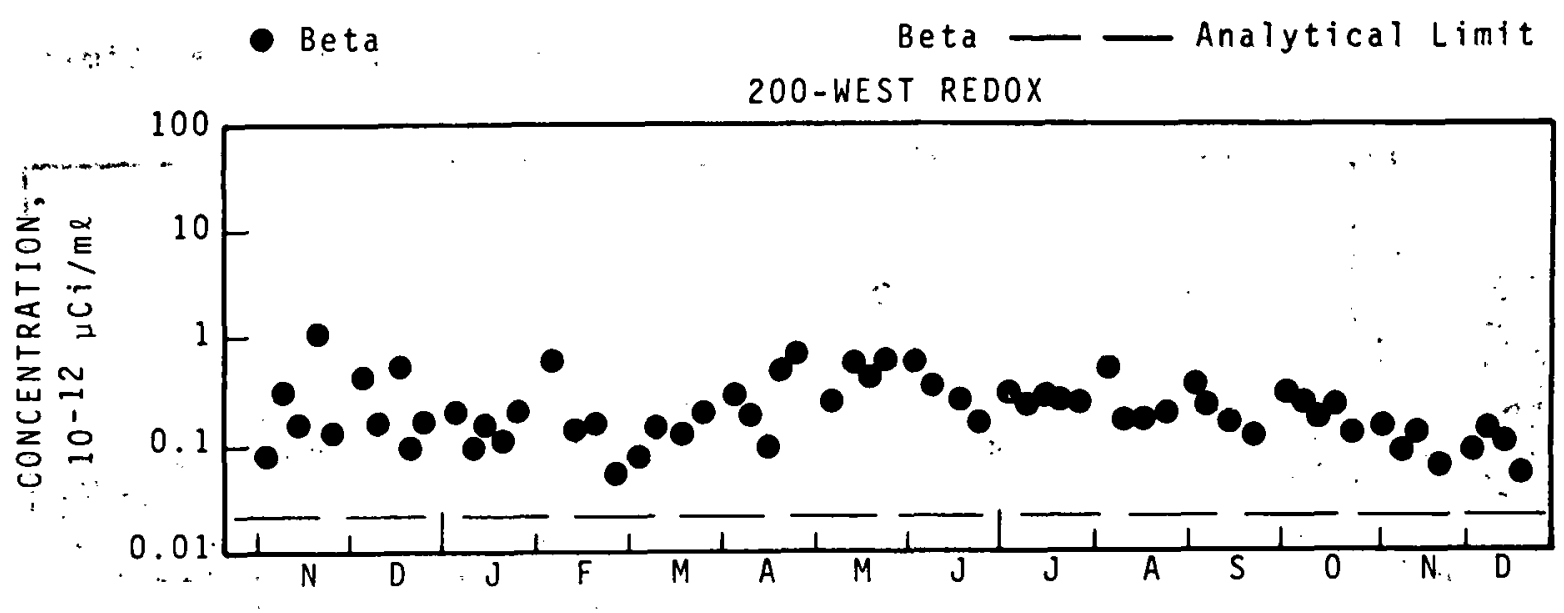

200-WEST EAST CENTER

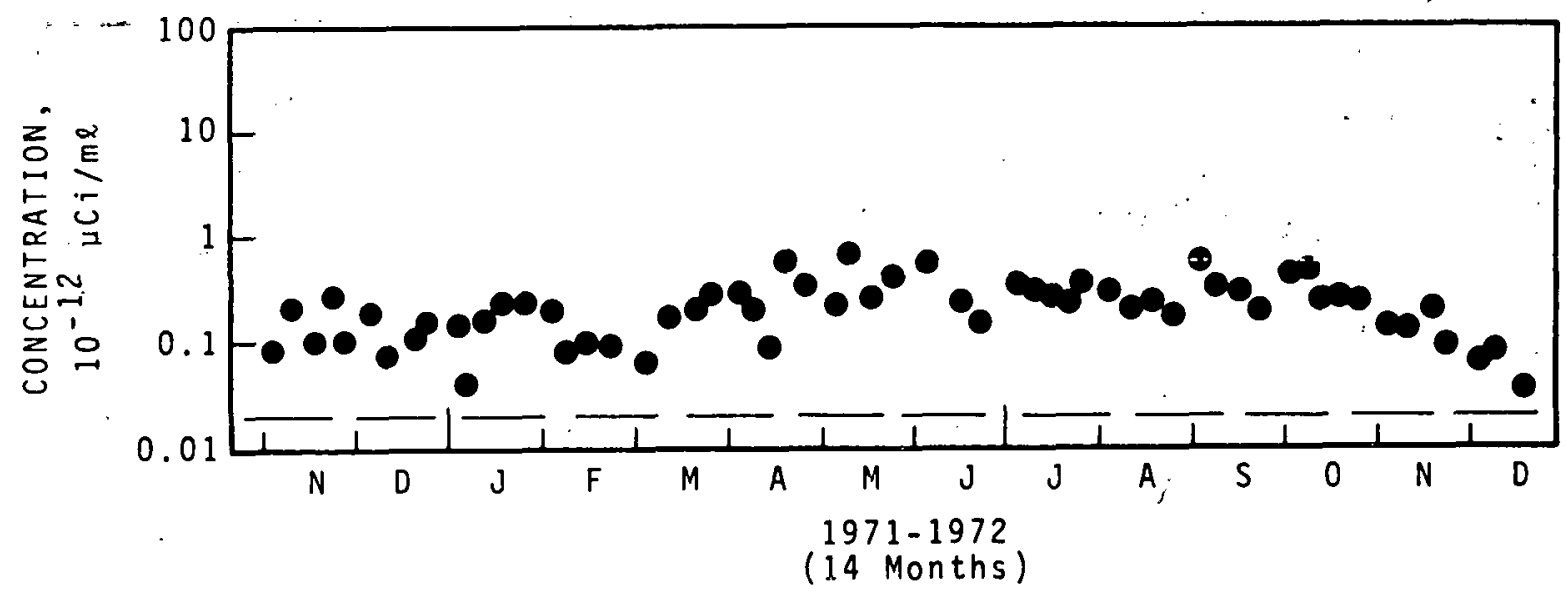


FIGURE 12

TOTAL BETA ACTIVITY IN THE ATMOSPHERE 200 AREAS AND INTERMEDIATE AREAS
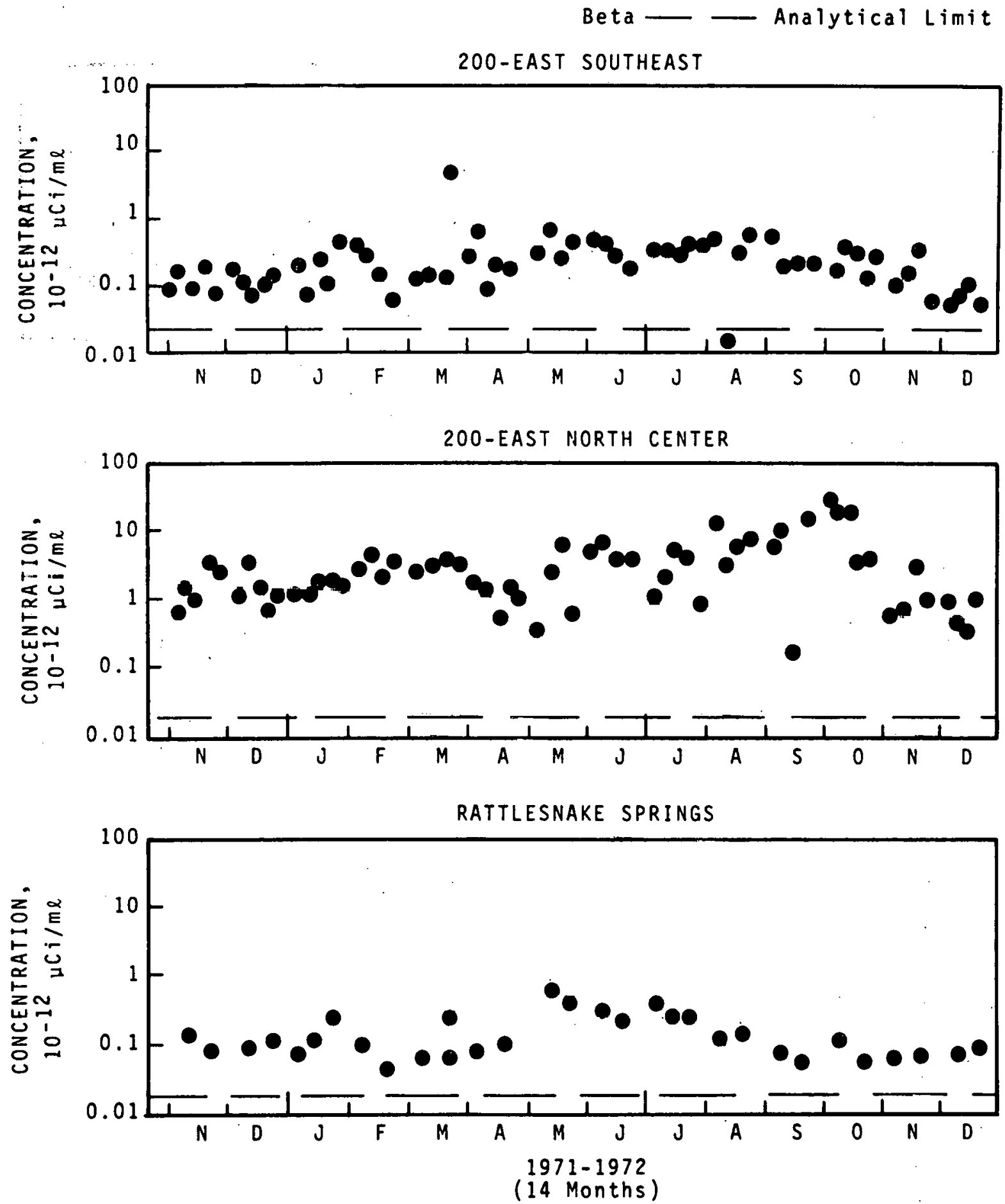
FIGURE 13

TOTAL BETA ACTIVITY IN THE ATMOSPHERE

INTERMEDIATE AREAS

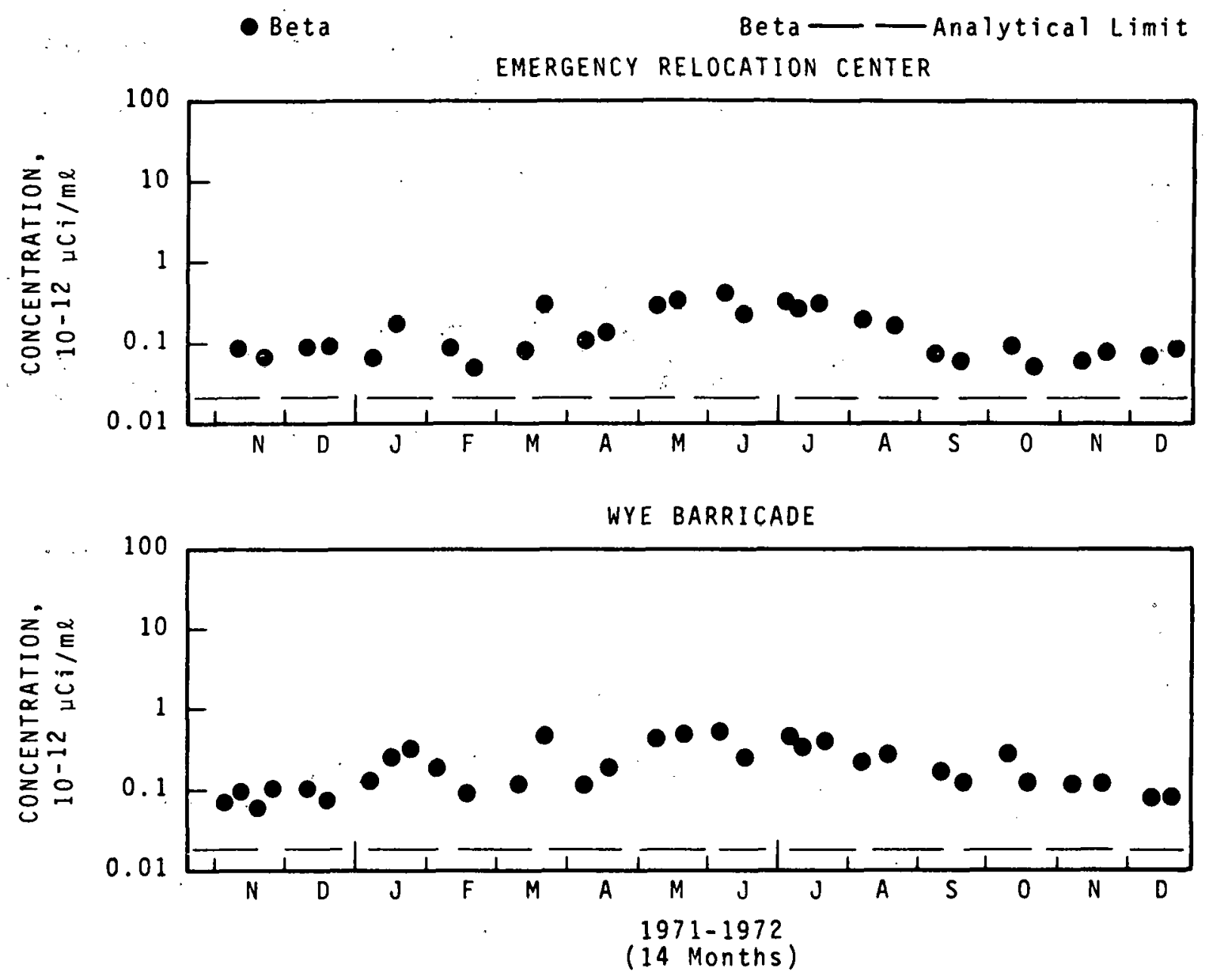


BNWL-B-278

FIGURE 14

TOTAL BETA ACTIVITY IN THE ATMOSPHERE 300 AND 700 AREAS

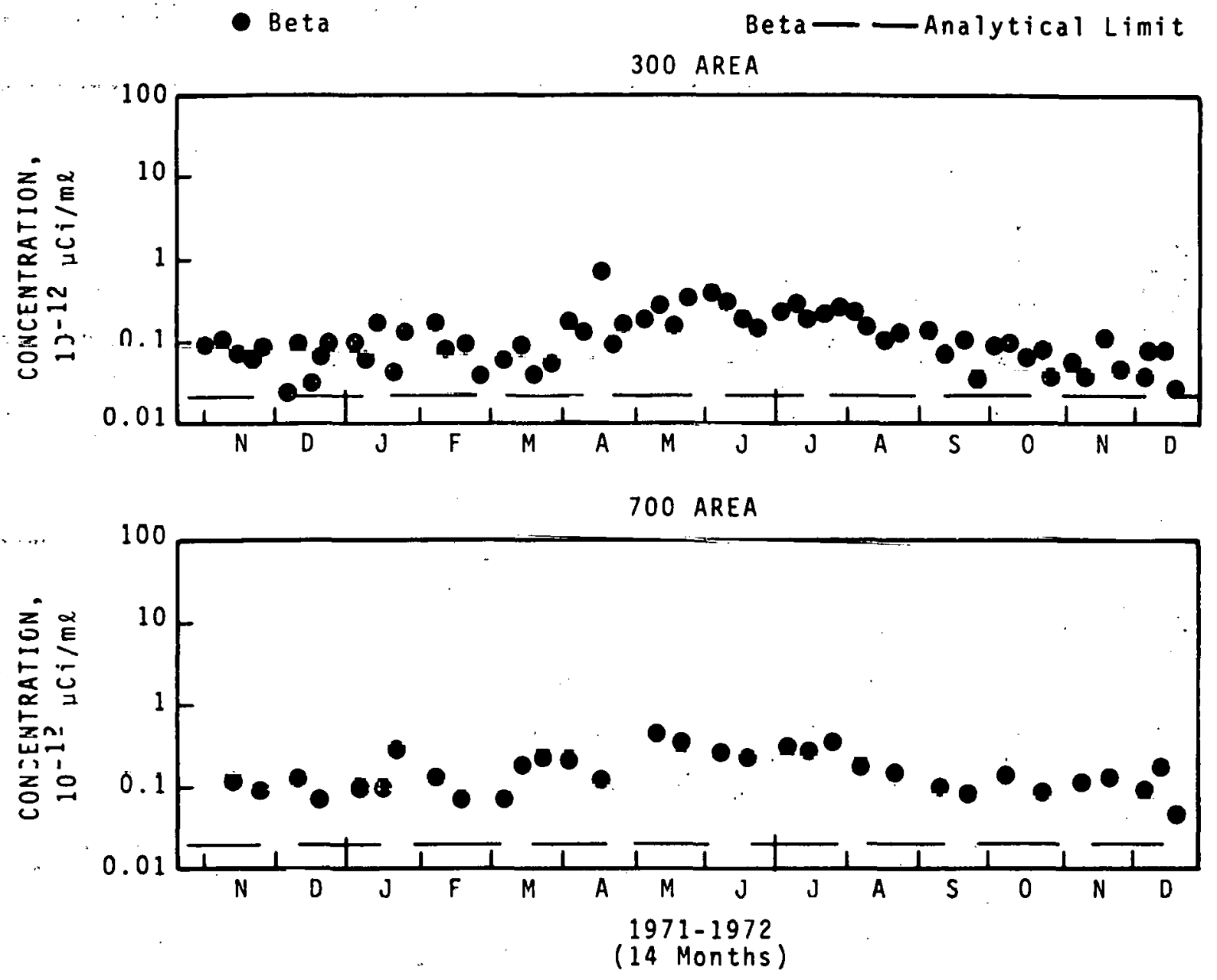




\section{SOIL AND VEGETATION}

Twenty-four locations for routine soil and vegetation sampling were established on and around the Hanford reservation in 1971. Specific locations are given in Map 6. Samples of the top two inches of soil and native vegetation (perennial) were taken at each of these locations at the end of September, 1972 and analyzed for plutonium, Sr-90, and gamma emitters. Gamma emitters in soil samples were measured with a lithium-drifted germanium detector, in vegetation samples with a sodium iodide crystal. As a result, slight differences in the gamma spectra were reported. Since the bulk of the vegetation was perennial, no conclusions should be drawn as to uptake of radionuclides from the soil.

The soil and vegetation results from thirteen perimeter and ten on-site locations are given in Tables 14 and 15. Concentrations averaged about the same as for 1971 except for Ru-106 and Cs-137 which were about a factor of four higher in 1972. CePr-144 was lower by a factor of ten from 1971 concentrations. Individual results showed no particular geographical pattern, and the concentrations measured are believed to be the result of regional fal1out. The plutonium concentrations are believed to be typical of general regional levels for the arid western states. As in 1971, average concentrations of several radionuclides in soil were marginally higher in the onsite samples compared to the perimeter samples. On-site plutonium-238 concentrations in soil and vegetation were statistically the same as the perimeter. The average plutonium-239 concentration appears to be higher in the surface inch of soil for on-site locations as compared to off-site. This is primarily the result of a reduction in the reported off-site plutonium concentrations compared to 1971 measurements. Relatively high Pu-239 concentrations were found in soil from Hanford, 200 fire station, 200-E Hi11, and Army Loop Road. 
BNWL-B-278

MAP 6

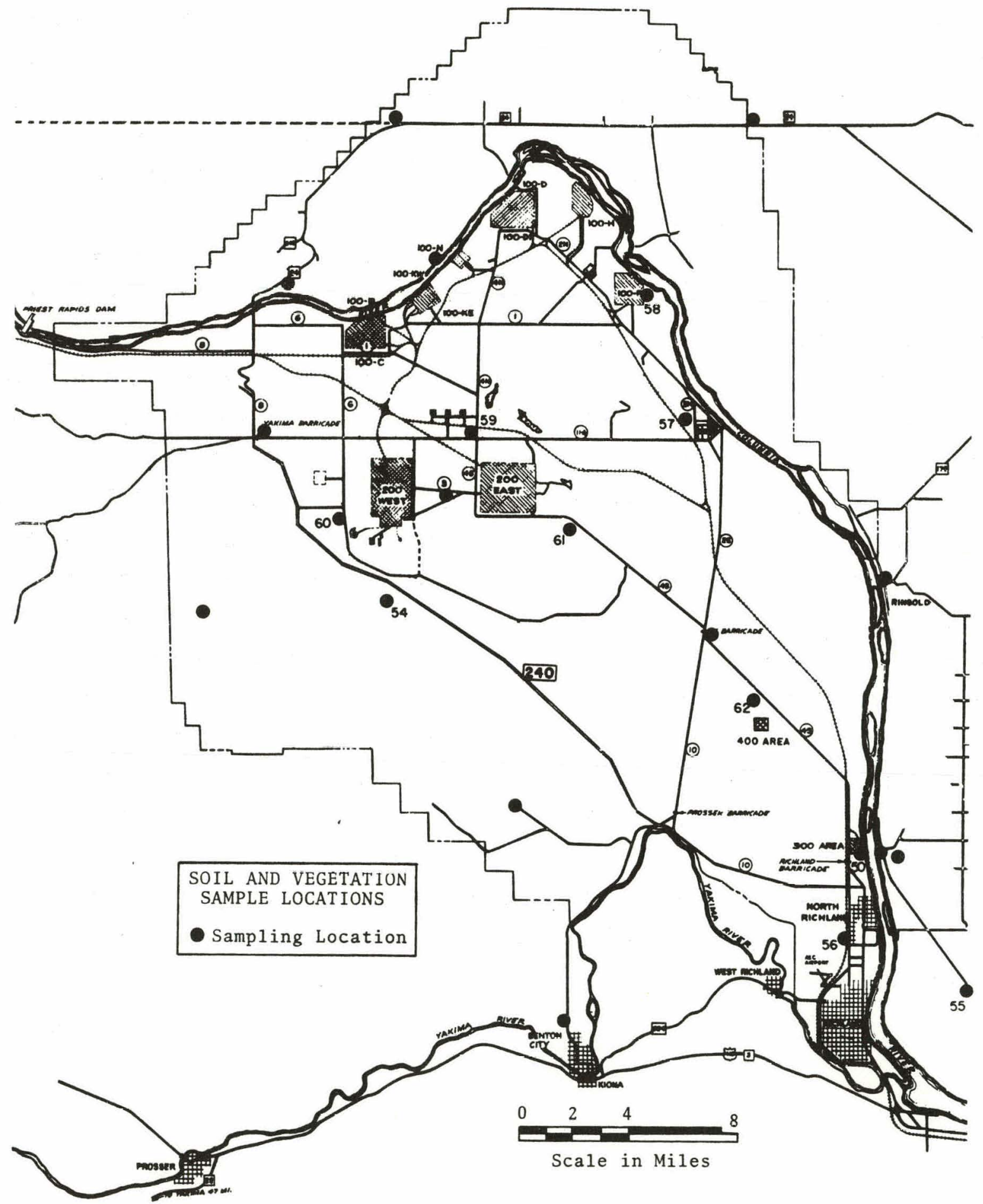


TABLE 14

CONCENTRATIONS OF RADIONUCLIDES IN SOIL SAMPLES - 1972

Units of $10^{-6} \mu \mathrm{Ci} / \mathrm{gm}$

On-Site

Location

W. of $100-\mathrm{N}$

331

Wye Barricade

Hanford

$100-\mathrm{F}$

200 Fire Station

200-E Hill

Rt. $4 \times 11$ A

Army Loop Road

Average On-Site

$\frac{\text { G }}{1}$

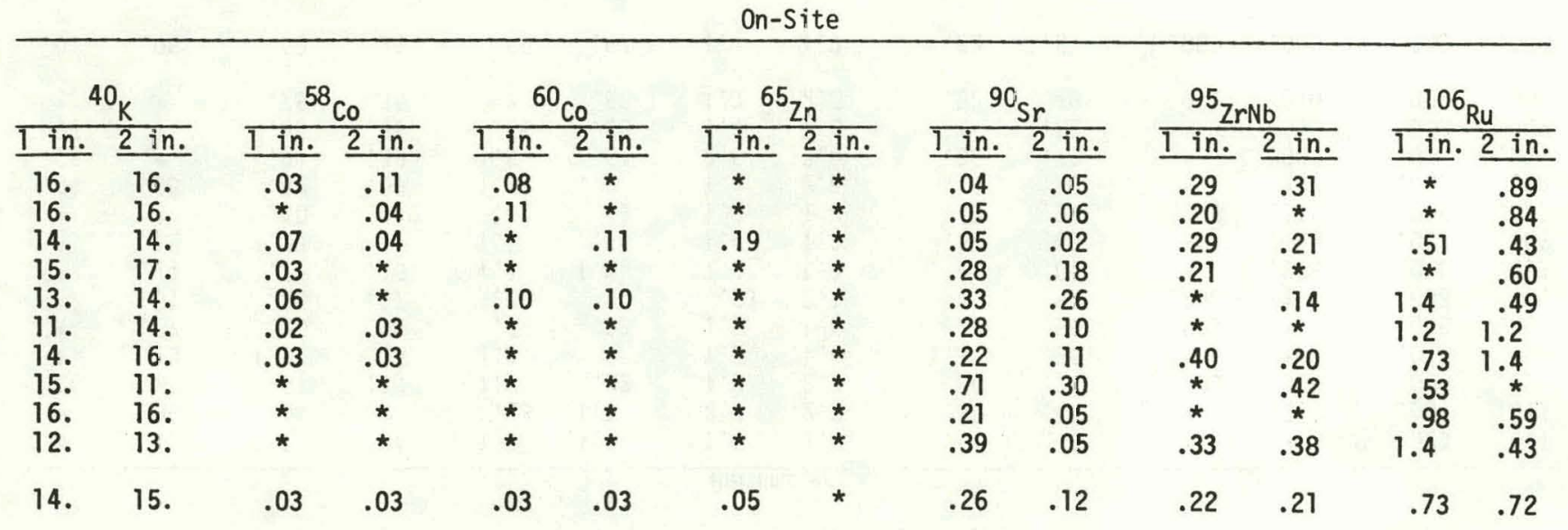

\section{Benton City}

ERC

Rt. 240 CP54

Rattlesnake Springs

Yakima Barricade

Vernita

Wahluke \#2

Berg Ranch

Ringold

Byers P.H.

Byers Landing

Riverview

North Richland

Average Perimeter

\begin{tabular}{ll}
\hline 14. & 14. \\
16. & 15. \\
14. & 15. \\
12. & 14. \\
13. & 12. \\
16. & 16. \\
12. & 14. \\
12. & 13. \\
16. & 14. \\
20. & 18. \\
18. & 13. \\
14. & 13. \\
16. & 14. \\
&
\end{tabular}

15.

Perimeter 
TABLE 14 (Continued)

CONCENTRATIONS OF RADIONUCLIDES IN SOIL SAMPLES - 1972

Units of $10^{-6} \mu \mathrm{Ci} / \mathrm{gm}$

Location

W. of $100-\mathrm{N}$

331

FFTF

Wye Barricade

Hanford

$100-\mathrm{F}$

200 Fire Station

200-E Hil1

Rt. $4 \times 11 \mathrm{~A}$

心

Army Loop Road

Average On-Site

On-Size

\begin{tabular}{|c|c|c|c|c|c|c|c|c|c|c|c|c|c|}
\hline \multicolumn{2}{|c|}{${ }^{134} \mathrm{Cs}$} & \multicolumn{2}{|c|}{${ }^{137} \mathrm{Cs}$} & \multicolumn{2}{|c|}{${ }^{144} \mathrm{CePr}$} & \multicolumn{2}{|c|}{${ }^{224} \mathrm{Ra}$} & \multicolumn{2}{|c|}{${ }^{226} \mathrm{Ra}$} & \multicolumn{2}{|c|}{${ }^{238} \mathrm{Pu}$} & \multicolumn{2}{|c|}{${ }^{239} \mathrm{Pu}$} \\
\hline in. & 2 in. & 1 in. & 2 in. & in. & 2 in. & in. & 2 in. & 1 in. & 2 in. & 1 in. & 2 in. & 1 in. & 2 in. \\
\hline * & .27 & .65 & .48 & $1 . \varepsilon$ & .76 & 2.1 & 1.6 & * & .61 & * & .006 & .015 & .022 \\
\hline$\star$ & * & .15 & .25 & .41 & * & 1.7 & .88 & .59 & .62 & $\star$ & .012 & .003 & .003 \\
\hline .05 & * & .13 & .06 & 39 & * & 1.0 & 1.2 & $\star$ & .47 & .004 & .006 & .005 & .011 \\
\hline$*$ & * & .76 & .42 & 9. & 1.3 & 1.5 & 2.4 & .50 & .79 & .003 & .005 & .014 & .016 \\
\hline .18 & .09 & 1.2 & .31 & .53 & .89 & .54 & 1.8 & $\star$ & .56 & .005 & $\star$ & .024 & .004 \\
\hline * & .06 & .65 & .41 & .97 & .74 & 1.6 & 1.3 & * & .44 & $\star$ & * & .009 & .005 \\
\hline * & .06 & .24 & .29 & .55 & .80 & 1.2 & 2.4 & .62 & .64 & * & * & .017 & .012 \\
\hline .08 & .04 & 1.8 & .14 & .81 & .75 & .88 & 1.6 & .59 & .51 & * & * & .023 & .008 \\
\hline$\star$ & .07 & .49 & .30 & .40 & .51 & 2.1 & 2.4 & .80 & .59 & * & * & .009 & .009 \\
\hline * & * & 1.4 & .31 & * & .84 & 1.3 & 3.2 & .56 & .88 & * & .006 & .021 & .009 \\
\hline .04 & .06 & .75 & .30 & .50 & .68 & 1.4 & 1.9 & .50 & .61 & .002 & .004 & .014 & .010 \\
\hline
\end{tabular}

Benton City

ERC

Rt. 240 CP54

Rattlesnake Springs

Yakima Barricade

Vernita

Wahluke \#2

Berg Ranch

Ringold

Byers P.H.

Byers Landing

Riverview

North Richland

Average Perimeter

\begin{tabular}{|c|c|c|c|c|c|c|c|c|c|c|c|c|c|}
\hline \multicolumn{14}{|c|}{ Perimeter } \\
\hline * & .10 & 1.1 & .84 & 1.3 & 1.4 & 1.6 & 1.8 & .61 & .55 & * & * & .023 & .011 \\
\hline * & .06 & .04 & * & .68 & 1.1 & 2.7 & 2.2 & .69 & .47 & * & .011 & .001 & .013 \\
\hline .04 & .01 & .51 & .19 & 1.2 & .32 & 1.9 & 2.3 & .84 & .77 & .003 & .004 & .006 & .004 \\
\hline * & .13 & 1.5 & .35 & 1.4 & $*$ & 1.9 & 1.6 & 1.3 & .86 & * & $*$ & .011 & .006 \\
\hline * & .07 & .26 & .36 & .52 & .93 & 1.6 & 1.6 & .72 & .56 & .003 & * & .005 & .005 \\
\hline * & .01 & .26 & .17 & .73 & * & $\begin{array}{l}.0 \\
.93\end{array}$ & 2.1 & $*$ & * & .008 & * & .003 & .001 \\
\hline * & .14 & .72 & .16 & 1.1 & 1.0 & 1.3 & 1.3 & * & .81 & * & .006 & .010 & .003 \\
\hline * & .12 & .23 & $*$ & 1.1 & .65 & 1.4 & 1.2 & .57 & .66 & * & .016 & .007 & .002 \\
\hline$\star$ & * & .40 & .048 & .92 & .49 & 1.8 & 1.8 & .48 & .94 & .005 & .016 & .008 & .022 \\
\hline .04 & .08 & .42 & .59 & 1.8 & 1.2 & 1.4 & 2.6 & .78 & .88 & $*$ & * & .003 & .003 \\
\hline .05 & $\star$ & .84 & .88 & 1.5 & .57 & 2.6 & 2.4 & .56 & .79 & * & .003 & .006 & .013 \\
\hline .05 & * & .55 & .45 & .66 & .52 & 1.4 & 1.6 & $*$ & .65 & $\star$ & $\star$ & .008 & .009 \\
\hline * & * & .75 & .36 & & .52 & 1.3 & 2.2 & .52 & .48 & .012 & .010 & .009 & .006 \\
\hline .01 & .06 & .58 & .34 & .99 & .67 & 1.7 & 1.9 & .62 & .67 & .003 & .005 & .008 & .008 \\
\hline
\end{tabular}

*Less than the analytical limit. 
TABLE 15

CONCENTRATIONS OF RADIONUCLIDES IN VEGETATION - 1972

Units $10^{-6} \mu \mathrm{Ci} / \mathrm{gm}$ of Vegetation

On-Site

Location

W of $100-\mathrm{N}$

331

FFTF

Wye Barricade

Hanford

100-F

Rt $4 \times 11 \mathrm{~A}$

Redox P.S.

200 Fire Station

$200 \mathrm{E}$. Hill

\section{verage}

On-Site

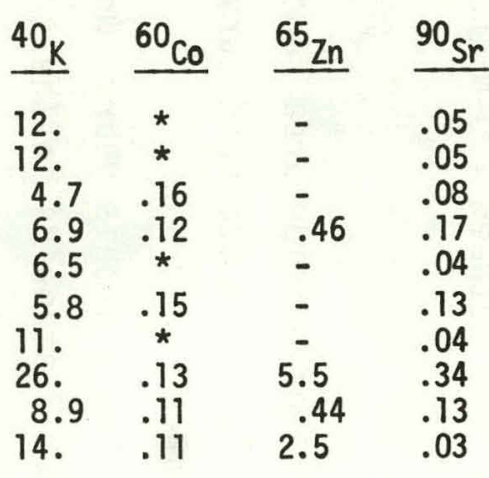

11. . $\begin{array}{lll}\text { 11 } & .09\end{array}$

\begin{tabular}{c}
$95 \mathrm{ZrNb}$ \\
\hline .44 \\
.91 \\
.79 \\
3.2 \\
1.7 \\
2.6 \\
.73 \\
18. \\
2.7 \\
8.7
\end{tabular}

4.0

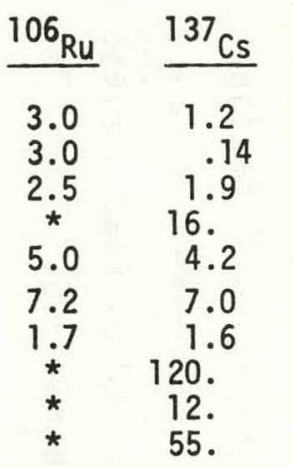

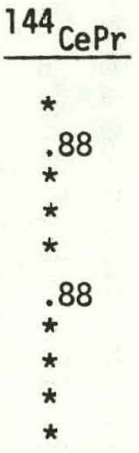

22.

\section{Perimeter}

Benton City

Rt 240 CP54

Rattlesnake Spring

Yakima Barricade

Vernita

Wahluke \#2

Berg Ranch

Ringold

Byers P.H.

Byers Landing

Riverview

North Richland

5.2
2.7
3.8
9.7
10.
7.1
9.8
11.
4.2
11.
21.
15.
7.9

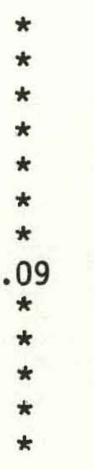

Average

Perimeter

$\begin{array}{ll}* & .08 \\ * & .11 \\ * & .12 \\ * & .03 \\ * & .07 \\ * & .11 \\ * & .06 \\ * & .10 \\ * & .05 \\ * & .05 \\ * & .07 \\ * & .85 \\ * & .04\end{array}$

$\begin{array}{lll}5.2 & .73 & 1.2 \\ 5.7 & 1.9 & 4.4 \\ 5.2 & 2.7 & \star \\ 2.9 & .97 & 1.2 \\ 4.6 & 1.7 & \star \\ 3.8 & 5.8 & \text { * } \\ 5.7 & .71 & \text { * } \\ 1.9 & 1.2 & \text { * } \\ 2.4 & .56 & \text { * } \\ 2.5 & 3.8 & \text { * } \\ 2.1 & 1.0 & \text { * } \\ \star & .24 & .82 \\ 2.4 & .79 & .82\end{array}$

3.5

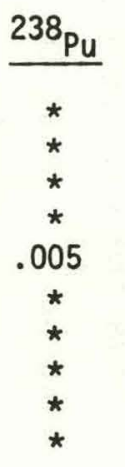

${ }^{239} \mathrm{Pu}$
.001
$\star$
.004
.004
.003
.002
$\star$
.007
.006
.008

\begin{tabular}{c}
$U$ \\
\hline ( $\mathrm{gm} / \mathrm{gm})$ \\
.13 \\
.22 \\
.05 \\
$\star$ \\
.01 \\
.05 \\
.02 \\
.05 \\
.16 \\
.03
\end{tabular}

$.001 \quad .004$

.07 


\section{RADIATION SURVEYS}

\section{A. Surface Contamination}

1. Hanford Roads Survey

Hanford roads are routinely surveyed (Map 7) with a bioplastic scintillation detector attached to the front end of a truck and positioned about 0.6 meters (2 ft.) above the road surface. This road monitor has been described in BNWL-62. (4) Most traveled roads within the Hanford reservation were surveyed monthly.

During the year, several radioactive particles were found on or llear Hanford roadways. The mnst. significant of these occurrences was at the NE corner of 200-East on 9/21/72, and was associated with a spot along the railroad, as reported in Section X.2, Railroad Survey.

Other contaminated objects detected by road survcys are as follows. Al1 of these objects were removed.

Apri1 20: One speck found outside of 100-N on main road, approximately $30,000 \mathrm{c} / \mathrm{m}$. This was attributed to the waste hauiing operation.

September 8: Three specks, maximum of 3,000 c/m, were found on the west shoulder of the road between $100-\mathrm{N}$ and the railroad tracks.

\section{Railroad Survey}

A11 Hanford railroad tracks located outside area fences are surveyed annually with the previously described road survey detector attached to a railroad maintenance car.

Only one contaminated spot was located this year. On Sept. 21, 1-1/2 miles west of 200-East gate at Station 84 in the track maintenance roadway a spot was found that read approximately $100,000 \mathrm{c} / \mathrm{m}$ at 2 feet above the ground. The recovered soil read $7.5 \mathrm{rads} / \mathrm{hr}$. Radioanalysis yielded the following results:

$$
\begin{aligned}
& \mathrm{Sr}-\mathrm{Y}-90 \\
& \mathrm{Ce}-\mathrm{Pr}-144 \\
& \mathrm{Ru}-\mathrm{Rh}-106 \\
& \mathrm{Cs}-137
\end{aligned}
$$$$
\begin{aligned}
& .018 \mu \mathrm{Ci} / \mathrm{gm} \\
& .001 \mu \mathrm{Ci} / \mathrm{gm} \\
& .0002 \mu \mathrm{Ci} / \mathrm{gm} \\
& .0001 \mu \mathrm{Ci} / \mathrm{gm}
\end{aligned}
$$

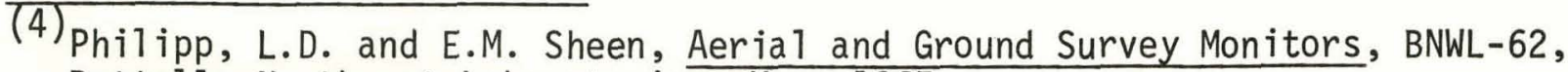
Battel 1e-Northwest Laboratories, May, 1965. 
BNWL-B-278

MAP 7

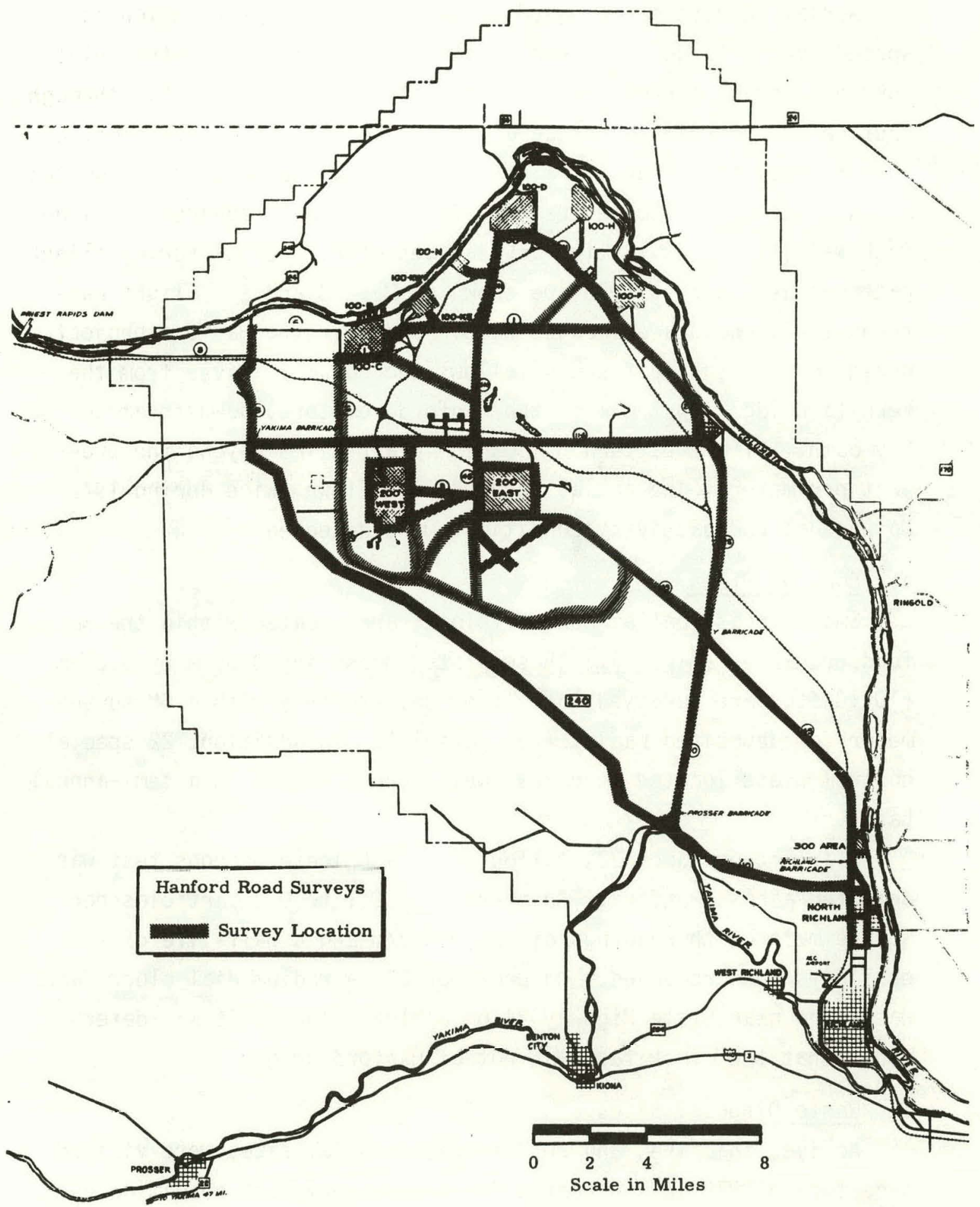




\section{$X . \quad$ RADIATION SURVEYS (Continued)}

\section{Aerial Surveys}

Aerial surveys can be used to detect contamination which is spread over a large land area. Like road, rail, and control plot surveys, aerial surveys are only qualitative in nature, but through routine use of this technique a capability for rapid assessment of an emergency situation is maintained. Aerial surveys are conducted at an altitude of 150 meters ( $500 \mathrm{ft}$.) using a three-inch by fiveinch NaI ( $\mathrm{Tl}$ ) scintillation crystal detector. Aerial survey flight patterns used during 1972 are shown on Maps 8 and 9. Flight patterns 1,2, and 3 are located within and near the Hanfurd project perimeter. Flight pattern 4 follows the Columbia River from the Vernita Bridge (upstream of the Hanford reactors) downstream to Plymouth. Flight pattern 5 lies 15-40 air miles beyond the project perimeter. The aerial surveys were flown twice during 1972. № unusual radioactivity conditions were detected.

\section{Control Plots}

Small areas, called control plots, are located within the Hanford boudaries (Map 10). These plots, measuring $3.05 \mathrm{~m}$ by $3.05 \mathrm{~m}$ (10x10 ft.) are surveyed monthly or semi-monthly with a GM survey meter for deposited radioactive material. In addition, 22 special control plots located near test wells are surveyed on a semi-annual basis.

Starting on March 22, fallout from a Chinese weapons test was detected across Hanford. An average of 0.1 to 0.2 particles per square meter with readings of $\leq 20,000 \mathrm{c} / \mathrm{m}$ and a half-1ife of several days were recorded. On December 27, a radium dial clock face was found near State Highway 24 on Wahluke Slope. It was determined that the clock face was not of Hanford origin.

\section{Waste Disposal Sites}

Active, inactive, and retired waste burial sites were visited once during 1972 and inspected for general physical condition and evidence of disturbance. The locations of such sites outside plant 
BNWL-B-278

MAP 8

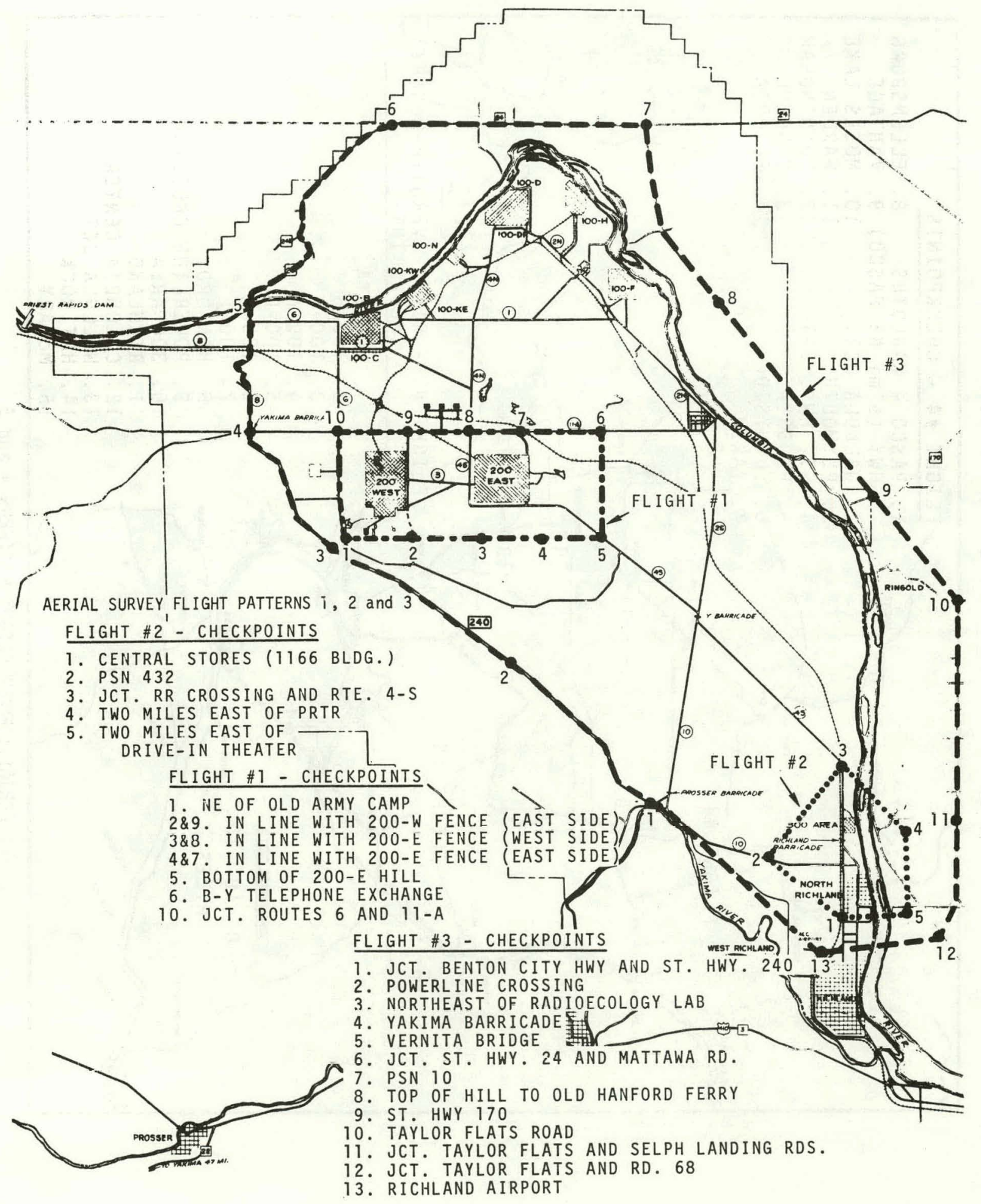


MAP 9

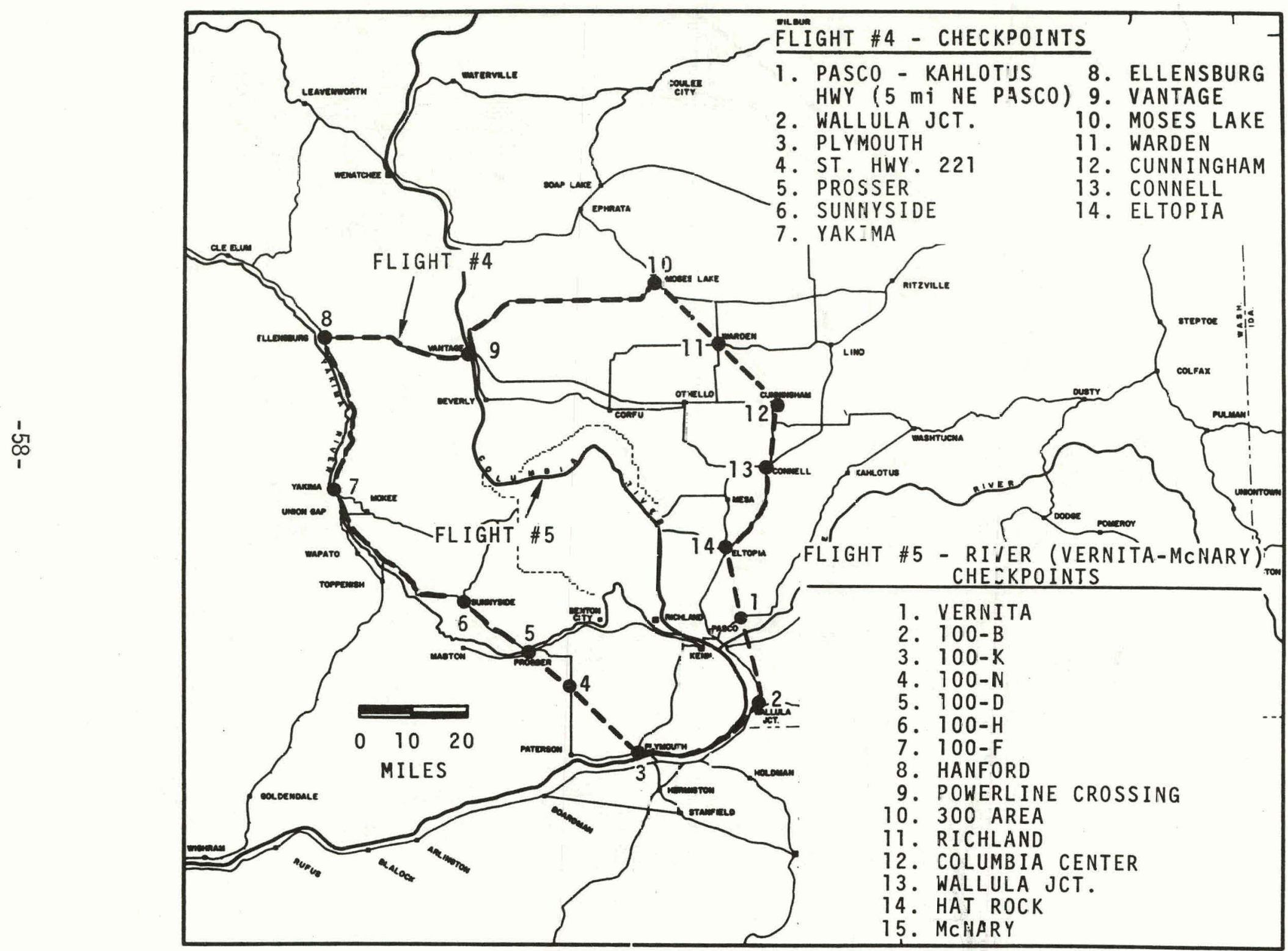


BNWL-B-278

MAP 10

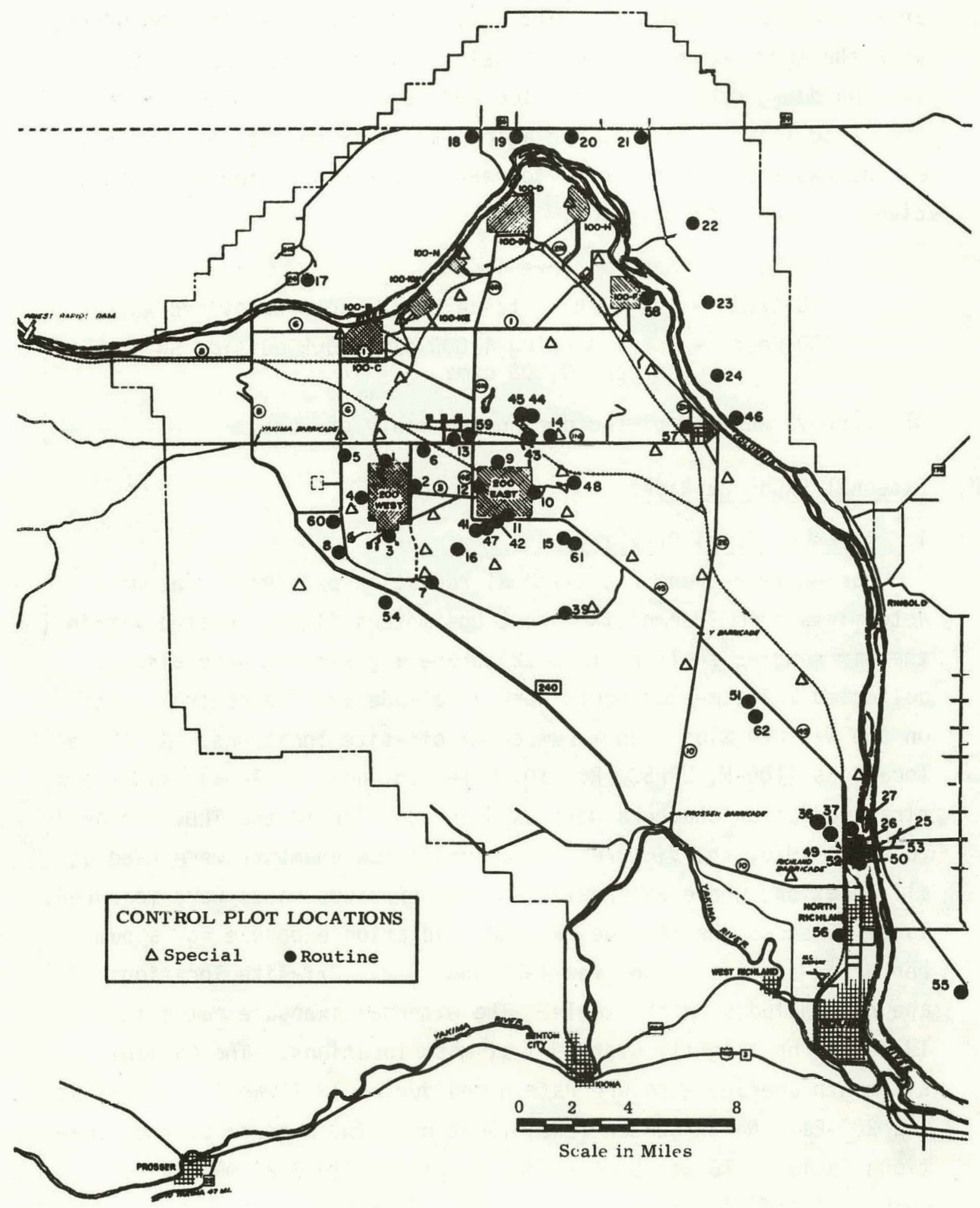


X. RADIATION SURVEYS (Continued)

5. Waste Disposal Sites (Continued)

areas are shown on Map 11. The sites were generally in good order, with the most recurring problem being housekeeping, such as signs falling down, chains not in place and vegetation growing inside the waste sites. Unusual radiation levels or conditions were noted as follows and were reported to responsible contractor representatives for corrective action:

$$
\begin{aligned}
& 100-B \quad \text { - Several cave-ins. } \\
& 100 \mathrm{D} / \mathrm{DR} \text { - } 100 \mathrm{mR} / \mathrm{hr} \text { outside basin, some uncovered waste. } \\
& \text { 300-West - Metal showing } 4,000 \mathrm{c} / \mathrm{m} \text {, junk outside } \mathrm{SW} \\
& \text { corner } 40,000 \mathrm{c} / \mathrm{m} .
\end{aligned}
$$

A11 surveys were completed during the month of June.

\section{B. External Exposure Rates}

1. Exposure Rates On-Plant

During 1972 trends in external radiation exposure rates were detcrmined from Thermoluminescent Dosimeters (TLD), located within the air sampler shel lers (Map 12) where air samples were also collected. TLD measurements were also made at nine control plots on the Wahluke Slope and a number of off-site locations. At three locations (100-N, WPPSS, Rt. 10, Mile 1.6, and 700-Area), Victoreen stray radiation chambers were used in addition to the TLD. Prior to July, 1970, the Victoreen stray radiation chambers were used at a11 locations where external radiation exposure rates were measured. Table 16 shows the average external radiation exposure for a number of on-site locations for 1971 and 1972. Off-site locations are not included in the table. The external exposure rates for 1972 were up slightly over 1971 at most locations. The maximum six-month average exposure rate noted during 1972 was $0.8 \mathrm{mR} /$ day at the 200-East North Center (ENC) location. The average of the locations in Table 16 was $0.26 \mathrm{mR} /$ day compared with $0.22 \mathrm{mR} /$ day for a number of off-site locations. At most locations, the external exposure rate was relatively constant. 


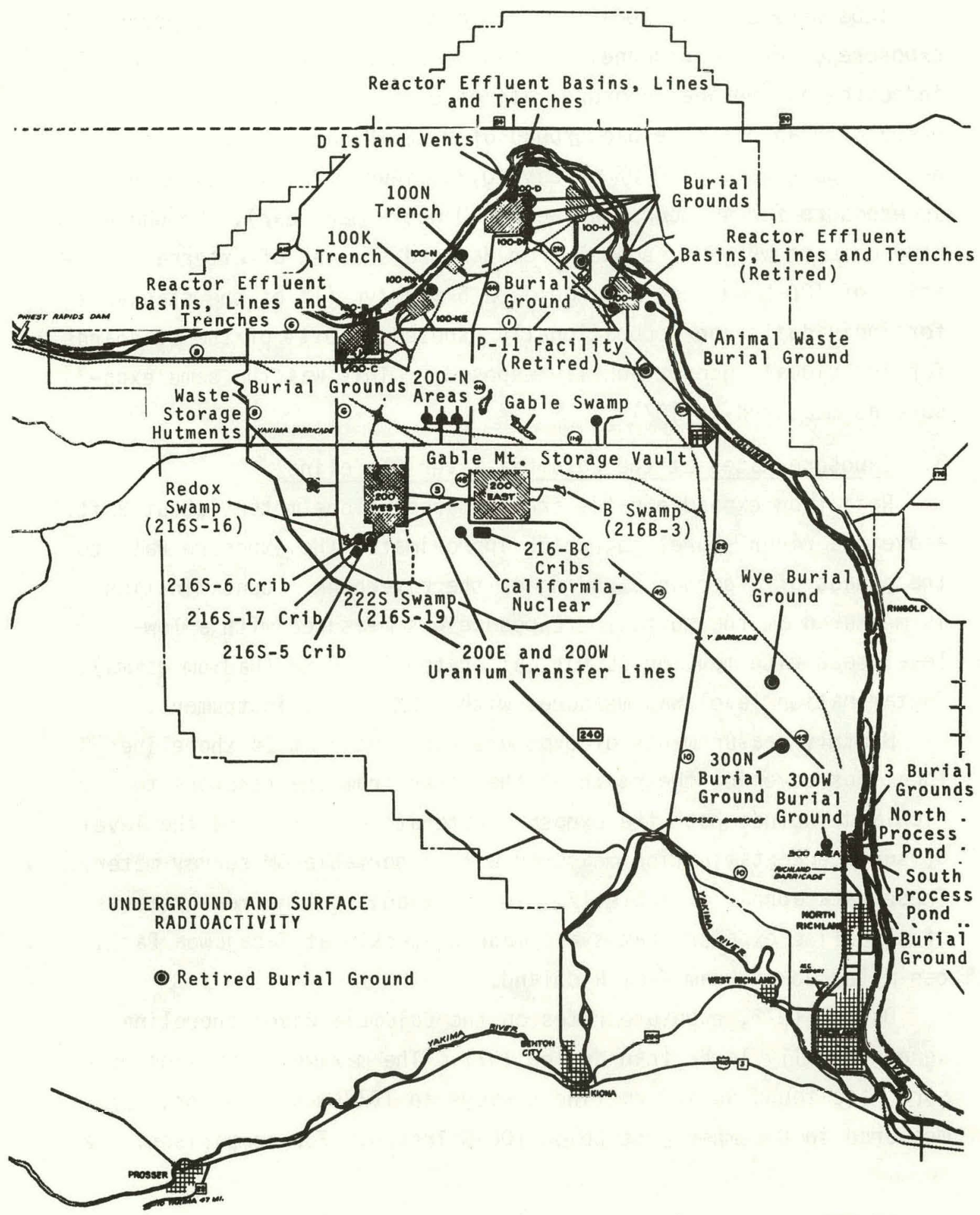




\section{RADIATION SURVEYS (Continued)}

2. 100-N Area

TLDs were used at 100-N Area in order to estimate the potential exposure of WPPSS personne1. Measurements with the TLD during 1972 indicated an average exposure rate of $0.29 \mathrm{mR} / \mathrm{day}$ at $100-\mathrm{N}$ compared with an off-site background of $0.22 \mathrm{mR} /$ day. Based on the net exposure rate of $0.07 \mathrm{mR} /$ day ( 0.29 minus 0.22 ) and assuming an exposure for 40 hours per week ( 50 weeks per year), the whole body dose to WPPSS personnel from Hanford sources of external radiation of 100-N during 1972 would be $5 \mathrm{mrem} / \mathrm{yr}$ ( $1 \%$ of the standards for individuals non-occupationally exposed or $0.1 \%$ of the standards for individuals occupationally exposed). This was the same exposure as measured in 1971.

\section{Exposure Rates at the Columbia River Shoreline}

Radiation exposure rates are measured at one meter (about $3 \mathrm{ft}$.) above the river shoreline, which approximates the exposure rate to the gonads of a person standing on the riverbank. Contamination is measured at the surface. Exposure was measured with a lowlevel dose rate monitor (LLM)* calibrated in $\mu \mathrm{R} / \mathrm{hr}$ (Radium gamma). Contamination level was measured with a GM survey instrument.

Monthly measurements of exposure rates made at 24 shoreline locations covering the reach of the river from the reactors to Richland include both the exposure rate at one meter and the levels of surface contamination measured with a portable GM survey meter. These data appear in Table 17. In addition, routine measurements of shoreline exposure rates are made bi-weekly at Sacajawea Park, ten miles downstream from Richland.

During 1972, exposure rates on the Columbia River shoreline were generally lower than during 1971. The maximum shoreline exposure rate found during routine surveys in 1972 was $28 \mu \mathrm{R} / \mathrm{hr}$, measured in December just below 100-N Trench. For comparison, the

*Manufactured by Nuclear Enterprises Limited, Canada. 


\section{RADIATION SURVEYS (Continued)}

3. Exposure Rates at the Columbia River Shoreline (Cont'd) maximum shoreline exposure rate measured during 1971 was $86 \mu \mathrm{R} / \mathrm{hr}$ at three locations---above $181 \mathrm{KE}, 100-\mathrm{F}$ Slough, and Hanford.

The maximum level of surface shoreline contamination encountered during 1972, $300 \mathrm{cpm}$ (GM), was detected below 100-N Trench location in January.

4. Exposure Rates Below the Surface of the Columbia River During 1972, exposure rates in the river were determined from TLD contained within submerged plastic bottles at the locations shown in Map 13.

Six-month averages for 1972 are shown in Table 18 with data from 1971 for comparison.

Exposure rates in the river during 1972 were about the same as the latter half of 1971. Prior to July, 1970, exposure rates in the river were determined from a cluster of five pencil ionization chambers. 


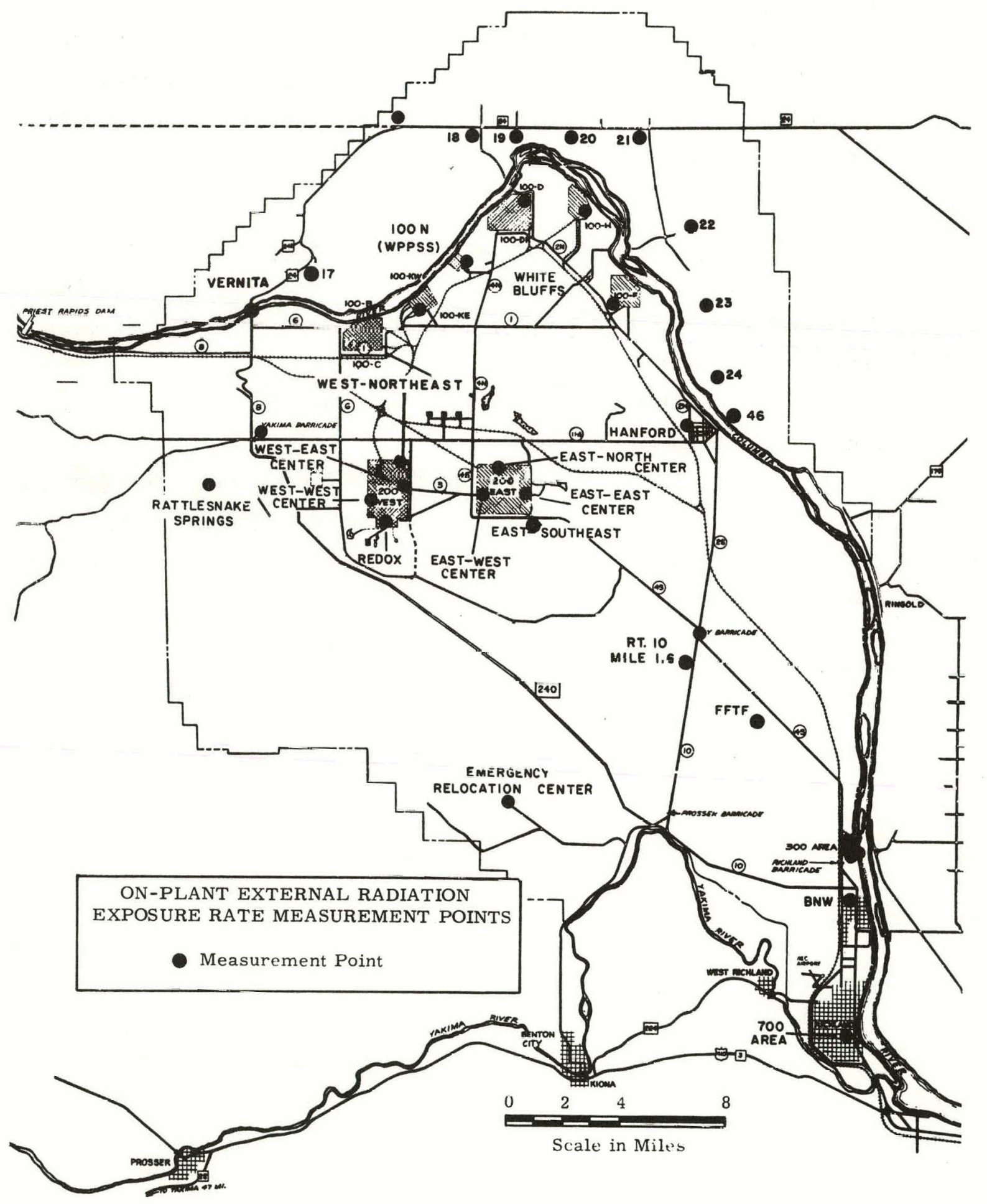




\section{TABLE 16}

\section{AVERAGE EXTERNAL GAMMA EXPOSURE RATES}

Units of $m R /$ day

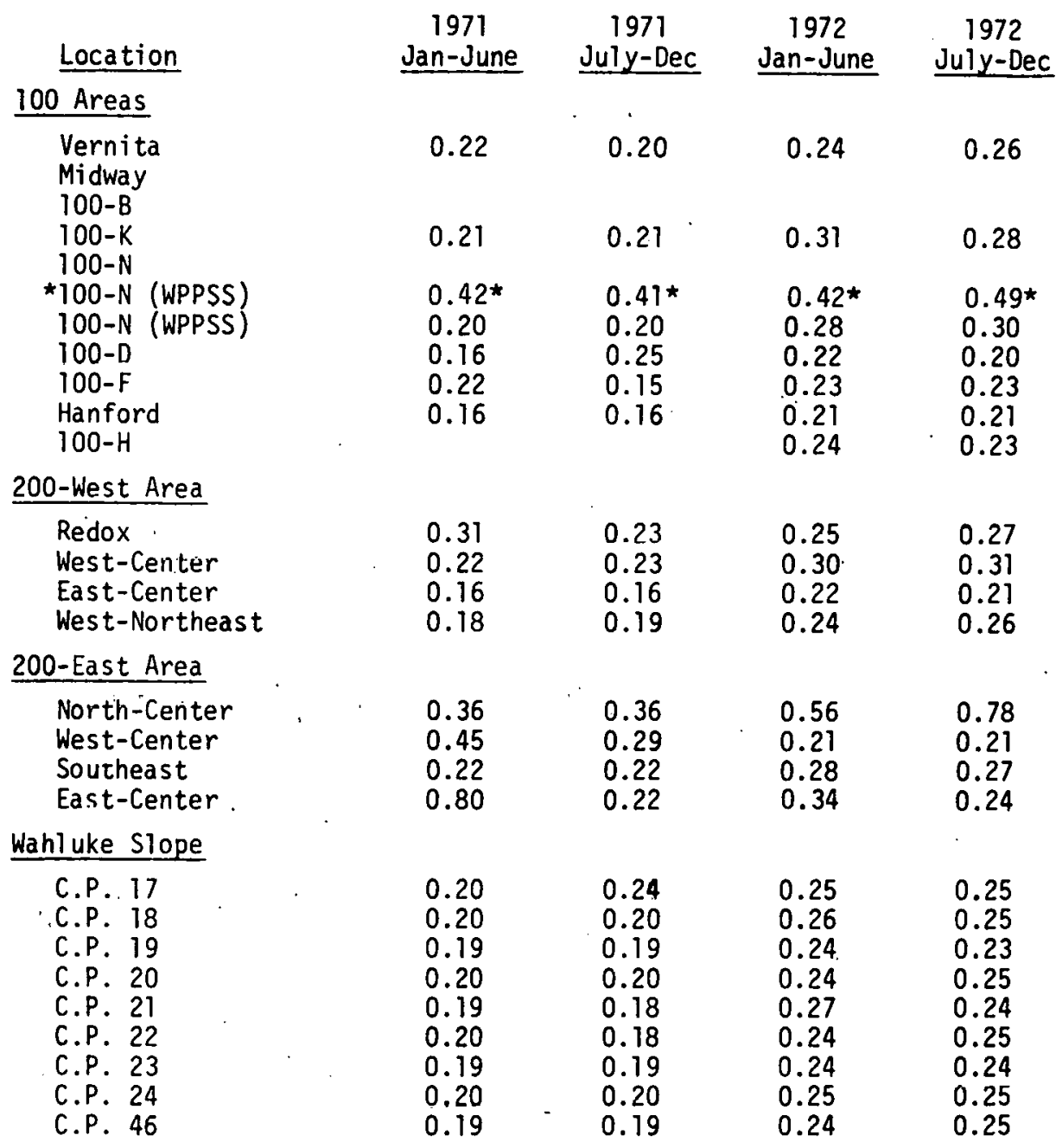

Other On-Site

$\begin{array}{lllll}\text { Yakima Barricade } & 0.18 & 0.20 & 0.28 & 0.25 \\ \text { Rattlesnake Springs } & 0.20 & 0.16 & 0.20 & 0.22 \\ \text { Emergency Relocation } & & & & \\ \text { Center } & 0.21 & 0.21 & 0.24 & 0.26 \\ \text { FFTF Site } & 0.20 & 0.18 & 0.23 & 0.23 \\ \text { WYE Barricade } & 0.16 & 0.15 & 0.19 & 0.20 \\ \text { *Rt. 10 Mile 1.6 } & 0.41^{\star} & 0.39^{\star} & 0.38^{\star} & 0.42^{\star} \\ \text { Rt. 10 Mile 1.6 } & 0.18 & 0.17 & 0.26 & 0.25 \\ \text { 300 Area (3705 Bldg) } & 0.22 & 0.21 & 0.26 & 0.24 \\ \text { 300 Area (320 Bldg) } & 0.20 & 0.16 & 0.26 & 0.25 \\ \text { 300 Area (331 Bldg) } & 0.23 & 0.17 & 0.22 & 0.23 \\ \text { 300 Pond } & 0.26 & 0.22 & 0.40 & 0.25 \\ \text { ACRMS } & 0.18 & 0.16 & 0.24 & 0.24\end{array}$

* Measurements with stray radiation chambers.

No entry indicates no measurement was performed. 
TABLE 17

MAXIMUM READINGS(a) FROM MONTHLY SHORELINE SURVEYS FOR 1972

( $\mu \mathrm{R} / \mathrm{hr}$ with $\mathrm{c} / \mathrm{m}$ in Parentheses)

A. COLLABIA RIVER PLAMT SHORE

\begin{tabular}{|c|c|c|c|c|c|c|c|c|c|c|c|c|c|c|c|c|c|c|c|c|}
\hline \multirow[t]{2}{*}{ Date } & \multicolumn{2}{|c|}{$\begin{array}{l}382.5 p(b) \\
\text { Above } 181 \mathrm{KN}\end{array}$} & \multicolumn{2}{|c|}{$\begin{array}{c}381.5 \mathrm{P} \\
\text { Below } 181 \mathrm{KE}\end{array}$} & \multicolumn{2}{|c|}{$\begin{array}{c}379.4 P \\
100-N \text { Trench } \\
\end{array}$} & \multicolumn{2}{|c|}{$\begin{array}{c}379.0 \mathrm{P} \\
\text { Below 100-N }\end{array}$} & \multicolumn{2}{|c|}{$\begin{array}{c}369.7 \mathrm{P} \\
\text { White 8luff Ferry }\end{array}$} & \multicolumn{2}{|c|}{$\begin{array}{c}368.3 \mathrm{P} \\
\text { 100-F Slough } \\
\end{array}$} & \multicolumn{2}{|c|}{$\begin{array}{l}362.0 \mathrm{P} \\
\text { Hanford }\end{array}$} & \multicolumn{2}{|c|}{$\begin{array}{c}350.4 P \\
\text { Powerline Cross. }\end{array}$} & \multicolumn{2}{|c|}{$\begin{array}{c}343.3 \mathrm{P} \\
\text { Port of Benton }\end{array}$} & \multicolumn{2}{|c|}{$\begin{array}{r}340.5 \mathrm{P} \\
\text { Richland } \\
\end{array}$} \\
\hline & $\underline{\underline{\mu M}}$ & (GM) & $\underline{L L M}$ & $(G M)$ & LLM & $(G M)$ & $\underline{\text { LLMM }}$ & $(G M)$ & ㄴM & $(G M)$ & $\underline{L L M}$ & (EX) & $\underline{L L M}$ & (GM) & $\underline{L L M}$ & $(G M)$ & $\underline{L L M}$ & (GM) & $\underline{L L M}$ & (GN) \\
\hline $\begin{array}{l}1 / 20 \\
2 / 23 \\
3 / 16 \\
4 / 26 \\
5 / 23 \\
6 / 21 \\
7 / 24 \\
8 / 18 \\
9 / 25 \\
10 / 20 \\
11 / 16 \\
12 / 19\end{array}$ & $\begin{array}{r}12 \\
12 \\
10 \\
8 \\
12 \\
12 \\
13 \\
15 \\
10 \\
12 \\
9 \\
10\end{array}$ & $\begin{array}{l}(150) \\
100 \\
100 \\
100 \\
150 \\
100) \\
100 \\
(150) \\
(100) \\
100 \\
100 \\
100)\end{array}$ & $\begin{array}{r}13 \\
12 \\
8 \\
12 \\
12 \\
10 \\
10 \\
15 \\
12 \\
20 \\
9 \\
11\end{array}$ & $\begin{array}{l}(150) \\
150 \\
(100) \\
(75 \\
(150 \\
200 \\
(100 \\
(150) \\
150 \\
150 \\
100 \\
(100)\end{array}$ & $\begin{array}{l}25 \\
15 \\
15 \\
14 \\
18 \\
20 \\
22 \\
15 \\
22 \\
23 \\
20 \\
28\end{array}$ & $\left.\begin{array}{l}(300 \\
150 \\
150 \\
150 \\
200 \\
200 \\
150 \\
170 \\
200 \\
150 \\
150 \\
(200)\end{array}\right)$ & $\begin{array}{l}18 \\
12 \\
10 \\
12 \\
15 \\
10 \\
10 \\
22 \\
11 \\
14 \\
12 \\
11\end{array}$ & $\begin{array}{l}(250) \\
100 \\
(100) \\
(150) \\
200 \\
150 \\
100 \\
100 \\
100 \\
150 \\
(100) \\
(100)\end{array}$ & $\begin{array}{r}13 \\
11 \\
8 \\
14 \\
14 \\
10 \\
8 \\
15 \\
10 \\
16 \\
11 \\
13\end{array}$ & $\begin{array}{l}200 \\
100 \\
150 \\
100 \\
200 \\
150 \\
100 \\
150 \\
100 \\
150 \\
100 \\
100\}\end{array}$ & $\begin{array}{r}10 \\
12 \\
9 \\
15 \\
14 \\
11 \\
15 \\
15 \\
18 \\
12 \\
12\end{array}$ & 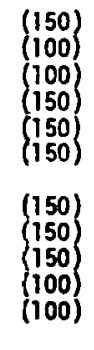 & $\begin{array}{r}15 \\
12 \\
8 \\
17 \\
12 \\
11 \\
12 \\
15 \\
15 \\
15 \\
11 \\
14\end{array}$ & $\begin{array}{l}250 \\
100 \\
100 \\
150 \\
150 \\
150 \\
150 \\
150 \\
150 \\
150 \\
150 \\
100 \\
(100)\end{array}$ & $\begin{array}{l}15 \\
13 \\
7 \\
22 \\
13 \\
11 \\
13 \\
15 \\
11 \\
17 \\
17 \\
12\end{array}$ & $\begin{array}{l}(150) \\
(150) \\
(100) \\
(150) \\
(150) \\
200 \\
100) \\
150 \\
125 \\
100 \\
(100) \\
(100)\end{array}$ & $\begin{array}{l}10 \\
11 \\
10 \\
13\end{array}$ & $\begin{array}{l}(100) \\
(100) \\
(100) \\
(100)\end{array}$ & $\begin{array}{l}12 \\
12 \\
10 \\
12 \\
12 \\
12 \\
7 \\
15 \\
12 \\
12 \\
10 \\
12\end{array}$ & 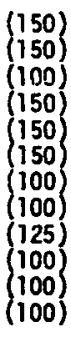 \\
\hline
\end{tabular}

B. COLLMBIA RIVER - ISLAND LOCATION

\begin{tabular}{|c|c|c|c|c|c|c|c|c|c|c|c|c|}
\hline \multirow[t]{2}{*}{ Date } & \multicolumn{2}{|c|}{$\begin{array}{r}377.4 \text { I } \\
\text { D Island }\end{array}$} & \multicolumn{2}{|c|}{$\begin{array}{l}375.8 \text { IF } \\
\text { E Is land }\end{array}$} & \multicolumn{2}{|c|}{$\begin{array}{c}373.4 \text { IP } \\
\text { Locke Island }\end{array}$} & \multicolumn{2}{|c|}{$\begin{array}{c}371.1 \text { IP } \\
\text { Locke Is land }\end{array}$} & \multicolumn{2}{|c|}{$\begin{array}{c}367.0 \text { If } \\
100-F \text { Slough }\end{array}$} & \multicolumn{2}{|c|}{$\begin{array}{l}355.7 \mathrm{I}^{\text {(d) }} \\
\text { Mear Ringold }\end{array}$} \\
\hline & $\underline{L L}$ & $(G M)$ & LLM & (GM) & $\underline{L L M}$ & (GM) & $\underline{\underline{\text { 느⿱ }}}$ & (ㅂ) & $\underline{\underline{L M}}$ & $(E \mathrm{~N})$ & LLM & (GI) \\
\hline $\begin{array}{l}1 / 20 \\
2 / 23 \\
3 / 16 \\
4 / 26 \\
5 / 23 \\
6 / 21 \\
7 / 24 \\
8 / 18 \\
9 / 25 \\
10 / 20 \\
11 / 16 \\
12 / 19\end{array}$ & $\begin{array}{l}20 \\
13 \\
10 \\
17 \\
10 \\
12 \\
13 \\
20 \\
15 \\
15 \\
9 \\
15\end{array}$ & $\begin{array}{l}\left(\begin{array}{l}200 \\
150 \\
100 \\
150 \\
150 \\
150 \\
150 \\
175 \\
150 \\
150 \\
100 \\
100\end{array}\right\} \\
\left\{\begin{array}{l}150 \\
1\end{array}\right.\end{array}$ & $\begin{array}{l}12 \\
10 \\
7 \\
11 \\
12 \\
10 \\
12 \\
12 \\
12 \\
15 \\
10 \\
13\end{array}$ & $\begin{array}{l}200 \\
100 \\
100 \\
100 \\
150 \\
150 \\
100 \\
150 \\
125 \\
150 \\
100 \\
100\end{array}$ & $\begin{array}{r}13 \\
12 \\
13 \\
13 \\
9 \\
17\end{array}$ & $\left.\begin{array}{l}(100) \\
150 \\
125 \\
700 \\
100 \\
100\end{array}\right)$ & $\begin{array}{l}12 \\
10 \\
7 \\
12 \\
11 \\
11 \\
12 \\
14 \\
12 \\
13 \\
10 \\
11\end{array}$ & $\left.\begin{array}{l}(150) \\
100 \\
(150 \\
100 \\
100 \\
(150 \\
100 \\
750 \\
125 \\
100 \\
100 \\
100\end{array}\right)$ & $\begin{array}{l}13 \\
13 \\
12 \\
17 \\
10 \\
15 \\
10 \\
18 \\
12 \\
12 \\
11 \\
14\end{array}$ & $\left\{\begin{array}{l}200 \\
150 \\
100 \\
150 \\
150 \\
150 \\
100 \\
150 \\
125 \\
100 \\
100 \\
100\end{array}\right)$ & $\begin{array}{r}10 \\
8 \\
14 \\
10 \\
10 \\
13 \\
15 \\
12 \\
14 \\
10 \\
13\end{array}$ & $\left\{\begin{array}{l}100 \\
150 \\
125 \\
100 \\
100 \\
100\end{array}\right)$ \\
\hline
\end{tabular}




\section{TABLE 17 (Continued)}

\section{MAXIMUM READINGS (a) FROM MONTHLY SHORELINE SURVEYS FOR 1972 ( $\mu \mathrm{R} / \mathrm{hr}$ with $\mathrm{c} / \mathrm{m}$ in Parentheses)}

C. COLUMBIA RIVER - FAR SHORE

\begin{tabular}{|c|c|c|c|c|c|c|c|c|c|c|c|c|c|c|c|c|}
\hline \multirow[t]{2}{*}{ De.te } & \multicolumn{2}{|c|}{$381.0 \mathrm{~F}$} & \multicolumn{2}{|c|}{$378.4 \mathrm{~F}$} & \multicolumn{2}{|r|}{$\begin{array}{l}369.8 \mathrm{~F} \\
\text { e Bluffs Ferry }\end{array}$} & \multicolumn{2}{|c|}{$\begin{array}{c}362.0 \mathrm{~F}^{(\mathrm{d})} \\
\underline{\text { Hanford }}\end{array}$} & \multicolumn{2}{|c|}{$\begin{array}{c}359.1 \mathrm{~F} \\
\text { vage Is I and }\end{array}$} & \multicolumn{2}{|c|}{$\begin{array}{c}354.7 \mathrm{~F}(\mathrm{c}) \\
\text { Ringold }\end{array}$} & \multicolumn{2}{|c|}{$350.4 \cdot F$} & \multicolumn{2}{|c|}{$\begin{array}{l}345.2 \mathrm{~F} \\
. \mathrm{s} \text { Landin }\end{array}$} \\
\hline & LLM & (GM) & LLM & (GM) & LLM & $(G M)$ & LLM & (GM) & LLM & $(G M)$ & LLM & (GM) & LLM & (GM) & LLM & (GM \\
\hline $\begin{array}{l}1 / 20 \\
2 / 23 \\
3 / 16 \\
4 / 26 \\
5 / 23 \\
6 / 21 \\
7 / 24 \\
8 / 18 \\
9 / 25 \\
10 / 20 \\
11 / 16 \\
12 / 19\end{array}$ & $\begin{array}{l}8 \\
9 \\
10 \\
10 \\
11 \\
10 \\
13 \\
15 \\
10 \\
20 \\
8 \\
12\end{array}$ & $\begin{array}{c}(100) \\
100 \\
(100) \\
(75) \\
(100) \\
(100) \\
(100) \\
(150) \\
(100) \\
(150) \\
(100) \\
(100)\end{array}$ & $\begin{array}{r}10 \\
8 \\
8 \\
10 \\
12 \\
10 \\
10 \\
15 \\
12 \\
13 \\
8 \\
15\end{array}$ & $\begin{array}{l}(150) \\
(100) \\
100) \\
(150) \\
(100) \\
(150) \\
(100) \\
(100) \\
(125) \\
(150) \\
(100) \\
(100)\end{array}$ & $\begin{array}{r}14 \\
13 \\
7 \\
11 \\
12 \\
10 \\
10 \\
12 \\
10 \\
11 \\
9 \\
12\end{array}$ & $\begin{array}{l}(200) \\
150 \\
(150) \\
(100) \\
(150) \\
(150) \\
100) \\
(150) \\
(100) \\
(100) \\
(100) \\
(100)\end{array}$ & $\begin{array}{r}15 \\
15 \\
8 \\
19 \\
10 \\
10 \\
12 \\
15 \\
12 \\
18 \\
12 \\
16\end{array}$ & $\begin{array}{l}(250) \\
(150) \\
(100) \\
(150) \\
(100) \\
(150) \\
(100) \\
150) \\
(125) \\
(150) \\
(100) \\
(100)\end{array}$ & $\begin{array}{l}10 \\
10 \\
10 \\
10 \\
10 \\
11 \\
11 \\
15 \\
12 \\
13 \\
11 \\
8\end{array}$ & $\begin{array}{l}150) \\
100 \\
100 \\
100 \\
100) \\
(150) \\
(100) \\
(150) \\
(125) \\
(100) \\
(100) \\
(100)\end{array}$ & $\begin{array}{r}10 \\
9 \\
8 \\
13 \\
10 \\
10 \\
10 \\
15 \\
12 \\
16 \\
10 \\
13\end{array}$ & $\begin{array}{l}(150) \\
100 \\
(100) \\
(150) \\
(100) \\
(150) \\
(150) \\
(150) \\
(125) \\
(75) \\
(100) \\
(100)\end{array}$ & $\begin{array}{r}13 \\
12 \\
9 \\
13 \\
12 \\
20 \\
10 \\
15 \\
12 \\
16 \\
11 \\
15\end{array}$ & $\begin{array}{l}(150) \\
150) \\
(100) \\
(150) \\
(150) \\
(200) \\
(100) \\
(150) \\
(125) \\
(75) \\
(100) \\
(100)\end{array}$ & $\begin{array}{l}25 \\
12 \\
7 \\
21 \\
10 \\
14 \\
13 \\
12 \\
14 \\
17 \\
13 \\
15\end{array}$ & $\begin{array}{l}(100 \\
(100\end{array}$ \\
\hline
\end{tabular}

(a) Measur ements reported in $\mu \mathrm{R} / \mathrm{hr}$ are taken 1 meter above the ground and 1 meter back

from the water's edge. Measurements reported in () are the maximum $\mathrm{c} / \mathrm{m}$ found with

a $G M$ in the immediate vicinity of the water's edge.

(b) River miles measured from the mouth of the Columbia. Plant shore, far shore, and island are designated by P, F, and I, respectively.

(c) Point open to the general public during the entire year.

(d) Point only open to the general public on Wednesdays, Saturdays, and Sundays, during the hunting season.

No entry indicates no measurement was performed. 
TABLE 18

AVERAGE EXPOSURE RATES BELOW THE SURFACE OF THE COLUMBIA RIVER (1970-1972)

$$
\text { Units of mR/day }
$$

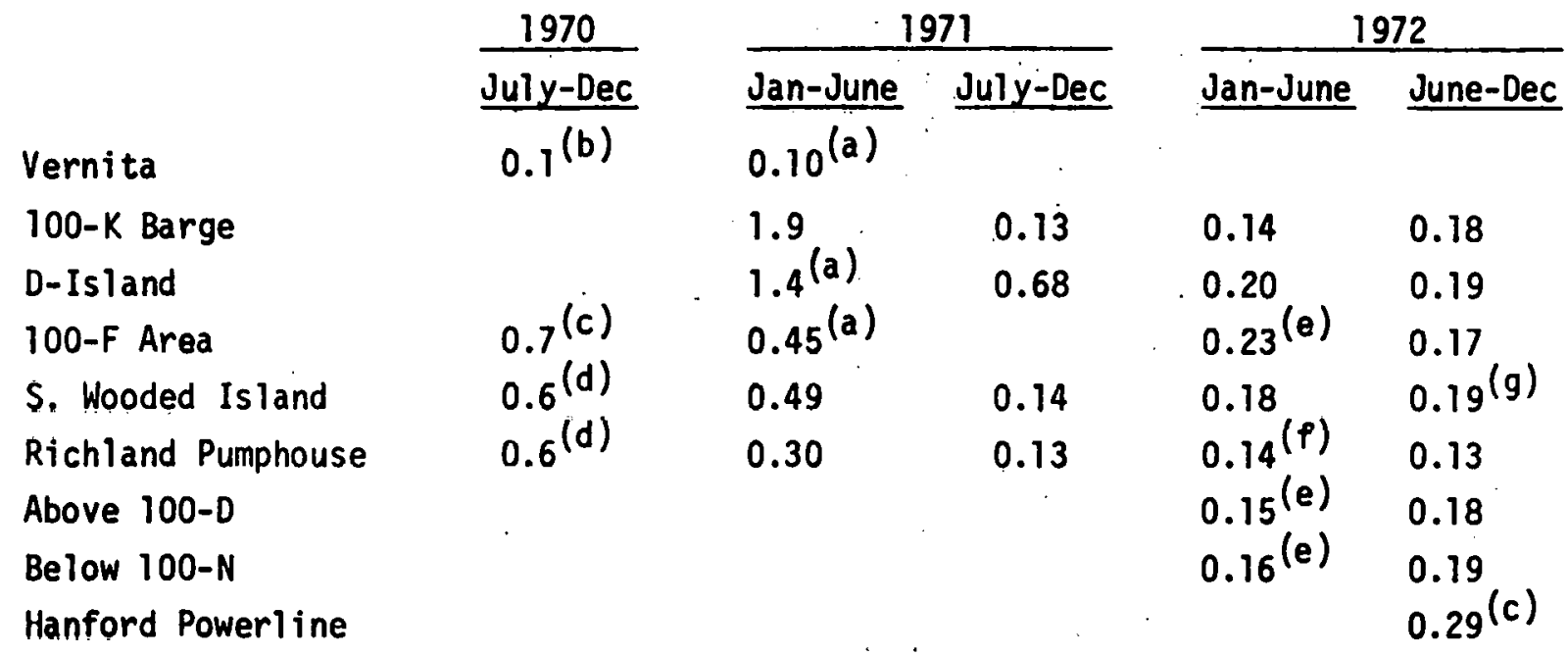

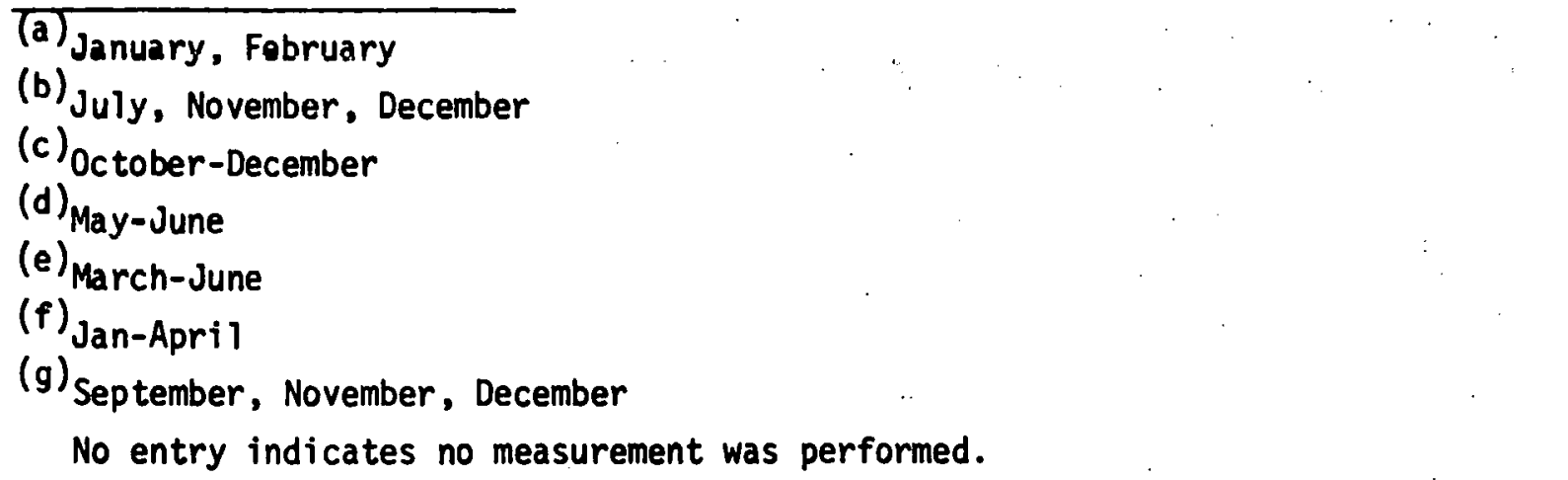




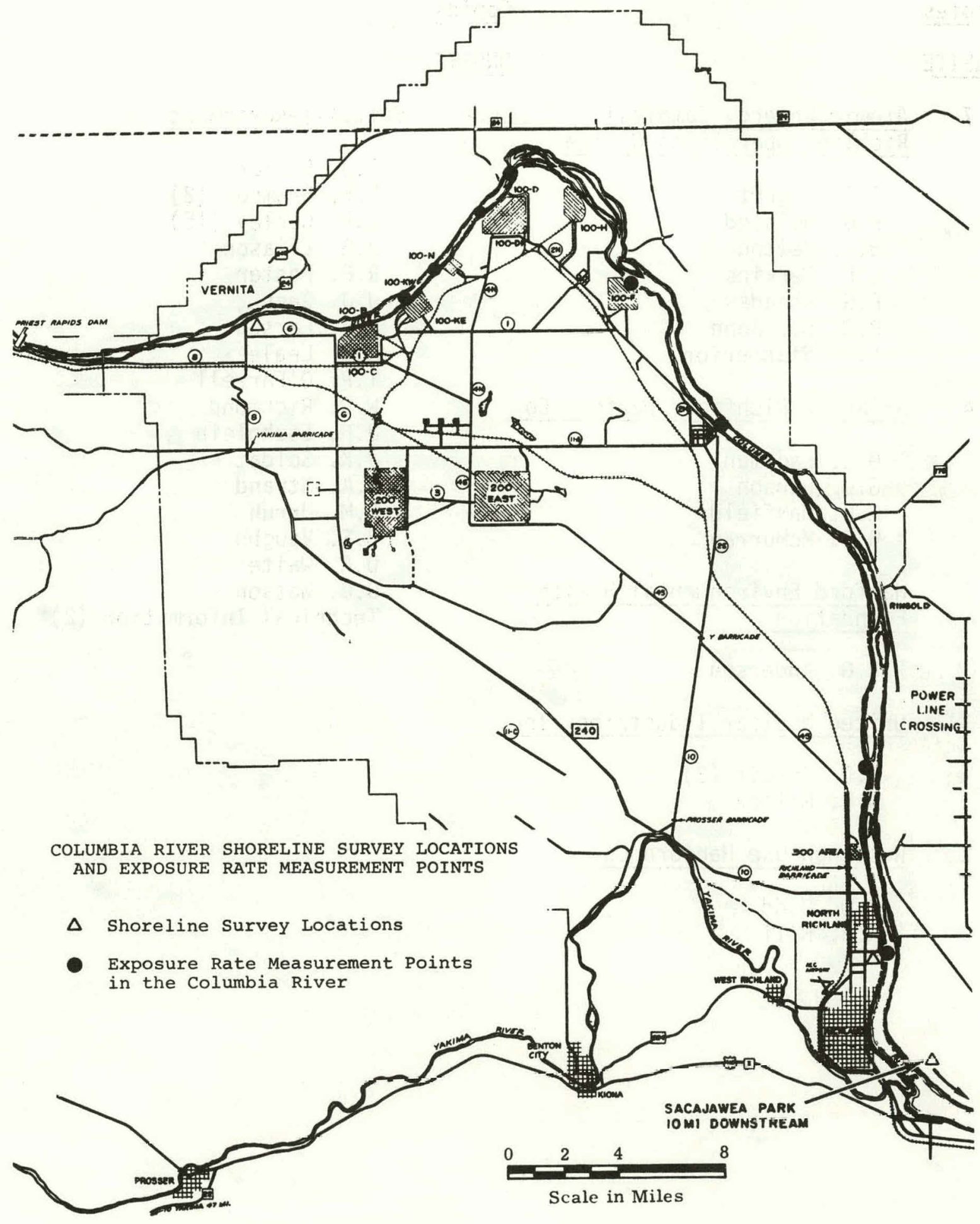




\section{DISTRIBUTION LIST}

No. of

Copies

\section{ONSITE}

7 Atomic Engergy Commission Rich7and Operations Office

0.J. Elgert

P.G. Holsted

B.J. Melton

L.F. Perkins

P.G. Rhoades

R.B. St. John

F.R. Standerfer

4 Atlantic Richfield Hanford Co.

G.E. Backman

G.L. Hanson

H.L. Maxfield

B.J. McMurray

1 Hanford Environmental Health Foundation

R.G. Anderson

3 United Nuclear Industries, Inc.

C.D. Corbit (2)

N.R. Miller

2 Westinghouse Hanford Co.

R.0. Budd

R.B. Hall
No. of

Copies

ONSITE
P.J. Blumer

P.E. Bramson (2)

J.P. Corley (15)

J.R. Eliason

R.F. Foster

J.J. Jech

H.V. Larson

M.W. Lcale

T.P. O'Farrel1

W.D. Richmond

J.H. Soehnlein

J.K. Soldat

J.A. Strand

C.M. Unruh

B.E. Vaughn

D.A. Waite

D.G. Watson

Technical Information (2) 